RECONNAISSANCE OF GEOHYDROLOGIC AREAS AND 1981 LOW-FLOW CONDITIONS, WITHLACOOCHEE RIVER BASIN, SOUTHWEST FLORIDA WATER MANAGEMENT DISTRICT

By Joel 0 . Kimrey and Warren Anderson

U.S. GEOLOGICAL SURVEY

Water-Resources Investigations Report 86-4203

Prepared in cooperation with the

SOUTHWEST FLORIDA WATER MANAGEMENT DISTRICT

Tallahassee, Florida

1987 
DEPARTMENT OF THE INTERIOR

DONALD PAUL HODEL, Secretary

GEOLOGICAL SURVEY

Dallas L. Peck, Director

For additional information write to:

District Chief

U.S. Geological Survey Suite 3015

227 North Bronough Street Tallahassee, Florida 32301
Copies of this report can be purchased from:

U.S. Geological Survey Books and Open-File Reports Section Federal Center, Bldg. 810 Box 25425

Denver, Colorado 80225 
Abstract

Introduction

Environmental setting $\ldots \ldots \ldots$

Climate -.....

Physiography and drainage $\ldots \ldots \ldots$

Geohydrology -..........

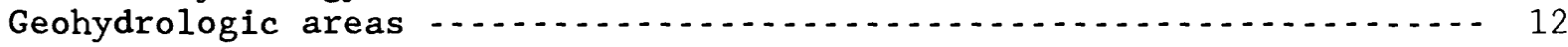

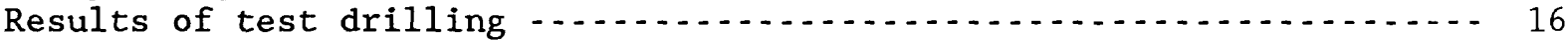

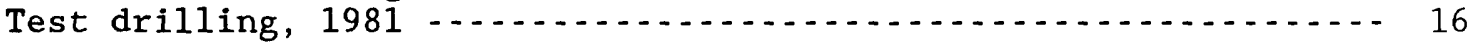

Withlacoochee State Forest . . . . . . .

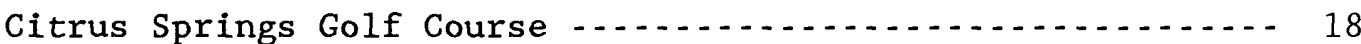

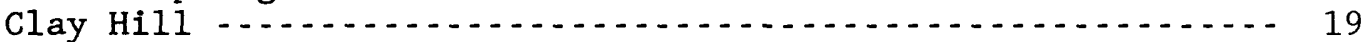

Test drilling, $1982 \ldots \ldots \ldots$

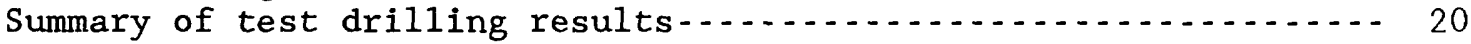

Conclusions on results of test drilling $\ldots \ldots$

Conceptualization of long-term effects of ground-water development --.- 22

Areas of high recharge

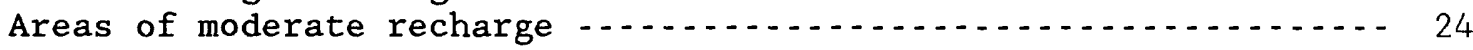

Low-flow conditions in the basin, April 13 through August 17, 1981,

in comparison with conditions during other periods of record ...... 24

Comparison of low-flow conditions in 1981 with low-flow conditions during other notable periods of deficient flow .... 25

Head relations in the basin, 1979-84, with emphasis on $1981 \ldots 28$

Exchange of water between the Withlacoochee River and the Upper

Floridan aquifer along selected reaches of the River in 1981 -. 30

Quality of surface water in the basin in April 1981, and comparison with quality in May $1979 \ldots$

Photographic documentation of low-flow conditions in the basin

in June and July $1981 \ldots \ldots$

Summary and conclusions -

References cited

\section{ILLUSTRATIONS}

Figures 1-8. Maps showing:

1. Surface-water data-collection sites in the SWFWMD Withlacoochee River Basin and

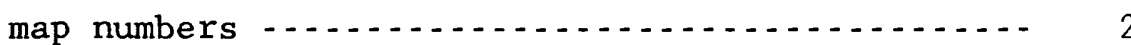

2. Relation of SWFWMD Withlacoochee River Basin and Green Swamp Basin management areas to the Withlacoochee River drainage basin .......... 5

3. Landforms in the SWFWMD Withlacoochee River

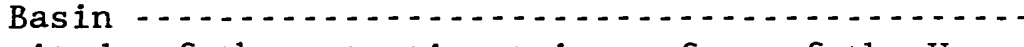

4. Altitude of the potentiometric surface of the Upper Floridan aquifer in May 1979, general directions of ground-water flow, and locations of ground-

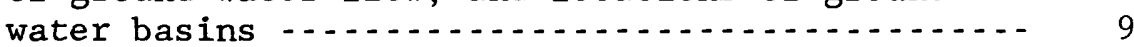

5. Areas of recharge to the Upper Floridan aquifer ... 10 
Figures 1-8. Maps showing--Continued

Page

6. Relation between the altitudes of the potentiometric surface and the top of the Upper Floridan aquifer, May 1979, and distribution of relatively impermeable deposits .......... 13

7. General distribution of geohydrologic areas ...... 15

8. Locations of test holes, Withlacoochee State

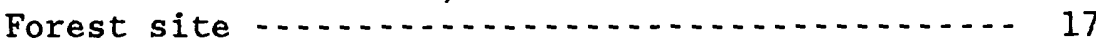

9-31. Photographs showing:

9. Withlacoochee River near Dade City (site 1) ..... 40

10. Withlacoochee River near Dade City (site 1) ..... 40

11. Withlacoochee River near Dade City (site 1) ...... 41

12. Withlacoochee River low-water channel above Dobes Hole near Lacoochee (site 2) ............ 41

13. Dobes Hole prairie near Lacoochee looking

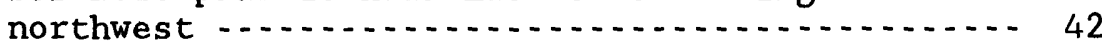

14. Dobes Hole near Lacoochee view from the north .... 42

15. Dobes Hole near Lacoochee (site 6) ............ 43

16. Dobes Hole outlet near Lacoochee (site 7) ...... 43

17. Withlacoochee River near Lacoochee (site 8) ...... 44

18. Withlacoochee River near Lacoochee (site 8) ..... 44

19. Withlacoochee River at Trilby (site 11) ....... 45

20. Withlacoochee River at Rital (site 14) ........ 45

21. Withlacoochee River at Rital (site 14) ........ 46

22. Withlacoochee River at outlet of Silver Lake downstream from Interstate Highway 75 bridge ... 46

23. Withlacoochee River at low-water control, 6,600 feet downstream from Croom (site 17) ........ 47

24. Withlacoochee River at low-water contro1, 6,600 feet downstream from Croom (site 17) ......... 47

25. Withlacoochee River at Nobleton (site 19) ....... 48

26. Withlacoochee River at Nobleton (site 19) ....... 48

27. Withlacoochee River at Nobleton (site 19) ....... 49

28. Withlacoochee River at Nobleton (site 19) ....... 49

29. Lake Panasoffkee near Lake Panasoffkee (site 25) - 50

30. Head of Outlet River at Panacoochee Retreats (site 25A) at outlet of Lake Panasoffkee near Lake Panasoffkee (site 25) ................. 50

31. Withlacoochee River near Holder (site 35) ...... 51

TABLES

Table 1. General stratigraphy and water-bearing properties of the Upper Floridan aquifer and overlying unconsolidated

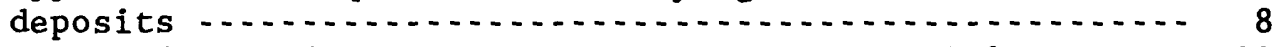

2. Summary of data for test holes drilled during $1982 \ldots \ldots . .21$

3. Map numbers, file numbers, and station names for datacollection sites in the Withlacoochee River Basin of the Southwest Florida Water Management District .......... 26 
Table 4. Discharge and rankings derived from flow-oriented analysis of low-flow conditions, Withlacoochee River at Trilby,

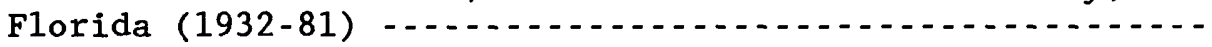

5. Discharge and rankings derived from flow-oriented analysis of low-flow conditions, Withlacoochee River near Holder,

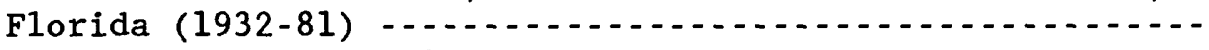

6. Periods of deficient flow, duration and ranking, and minimum discharge and ranking derived from time-oriented analysis of low-flow conditions, Withlacoochee River at

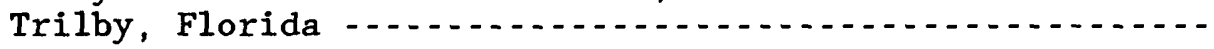

7. Periods of deficient flow, duration and ranking, and minimum discharge and ranking derived from time-oriented analysis of low-flow conditions, Withlacoochee River near

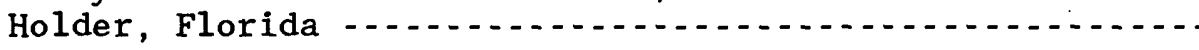

8. River water-surface (WS) altitudes, Upper Floridan aquifer potentiometric surface (PS) altitudes, head difference (HD), and discharge (Q) at selected sites in the Withlacoochee River basin (1979-84)

9. Calculated seepage rates along selected reaches of the Withlacoochee River when change in channel storage

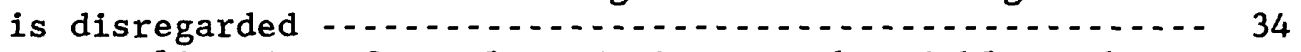

10. Water-quality data for selected sites in the Withlacoochee River basin in May 1979 and April 1981 


\section{ABBREVIATIONS AND CONVERSION FACTORS}

The inch-pound units used in this report may be converted to metric (International system) units by the following factors.

Multiply inch-pound unit

Length
inch (in.)
foot ( $f t)$
25.4
mile (mi)
0.3048
1.609

square mile $\left(\mathrm{mi}^{2}\right)$

gallon per minute per foot

[(gal/min)/ft]

cubic foot per second

$\left(f t^{3} / s\right)$
2.59

0.06308

0.2070

By

0.02832
To obtain metric unit

$$
\begin{aligned}
& \text { millimeter }(\mathrm{mm}) \\
& \text { meter }(\mathrm{m}) \\
& \text { kilometer }(\mathrm{km})
\end{aligned}
$$

Temperature in degrees Celsius can be converted to degrees Fahrenheit as follows :

$$
{ }^{\circ} \mathrm{F}=1.8 \times{ }^{\circ} \mathrm{C}+32
$$

\section{Additional abbreviation}

$$
\mathrm{mg} / \mathrm{L}=\text { milligrams per liter }
$$

$$
* * *
$$

Altitude: In this report "altitude" is referred to the National Geodetic Vertical Datum of 1929 (NGVD of 1929)--a geodetic datum derived from a general adjustment of the first-order level nets of both the United States and Canada, formerly called "Mean Sea Level of 1929."

$$
* * *
$$




\title{
RECONNAISSANCE OF GEOHYDROLOGIC AREAS AND 1981 LOW-FLOW CONDITIONS, WITHLACOOCHEE RIVER BASIN, SOUTHWEST FLORIDA WATER MANAGEMENT DISTRICT
}

By Joe1 0. Kimrey and Warren Anderson

\begin{abstract}
The Withlacoochee River Basin of the Southwest Florida Water Management District is a management area of about 2,030 square miles in west-central Florida containing large reserves of potable ground water in the Upper Floridan aquifer. Results of reconnaissance test drilling indicate that the Upper Floridan aquifer may be treated as an unconfined aquifer in the management area which allows it to be divided into two types of geohydrologic areas: (1) areas of high recharge, and (2) areas of moderate recharge. Conceptually, the source of water to well fields in areas of high recharge would largely be natural recharge, whereas, in areas of moderate recharge, a significant part of the source of water to well fields would be induced downward leakage, or capture, of surface and near-surface water.

The Withlacoochee River Basin of the Southwest Florida Water Management District is drained almost entirely by the Withlacoochee River and its tributaries. Field data were collected from April 13 through August 17, 1981, to document extremely low streamflow conditions. Conditions in the upper half of the drainage basin were found to be the most severe of record. On July 7, 1981, the total net runoff from the upper half of the basin was observed to be only 0.1 cubic foot per second. Low-flow conditions in the lower half of the drainage basin, however, were less severe than during the record low period of 1956.
\end{abstract}

\section{INTRODUCTION}

The Withlacoochee River Basin of the Southwest Florida Water Management District (SWFWMD) is a water-management area of about 2,030 $\mathrm{mi}^{2}$ (square miles) in west-central Florida (fig. 1) that is drained almost entirely by the Withlacoochee River and its tributaries. The predominant source of water for public, industrial, and irrigation supplies in this area is the Upper Floridan aquifer. The SWFWMD Withlacoochee River Basin is an area with relatively little water use but with large potential for potable water development, particularly from the Upper Floridan aquifer.

In 1977, the U.S. Geological Survey, in cooperation with the SWFWMD, began a long-range multiphase program to evaluate the water-resource potential of the Upper Floridan aquifer throughout the SWFWMD Withlacoochee River Basin. Prior to this time, there had been no comprehensive hydrologic appraisal of the entire management area, though its area comprises about 20 percent of the SWFWMD. Phase I of this investigative program, accomplished from October 1, 1977, through September 30, 1979, was a detailed reconnais sance of the Upper Floridan aquifer throughout the Basin. Specifically, the objectives of Phase I were to: 


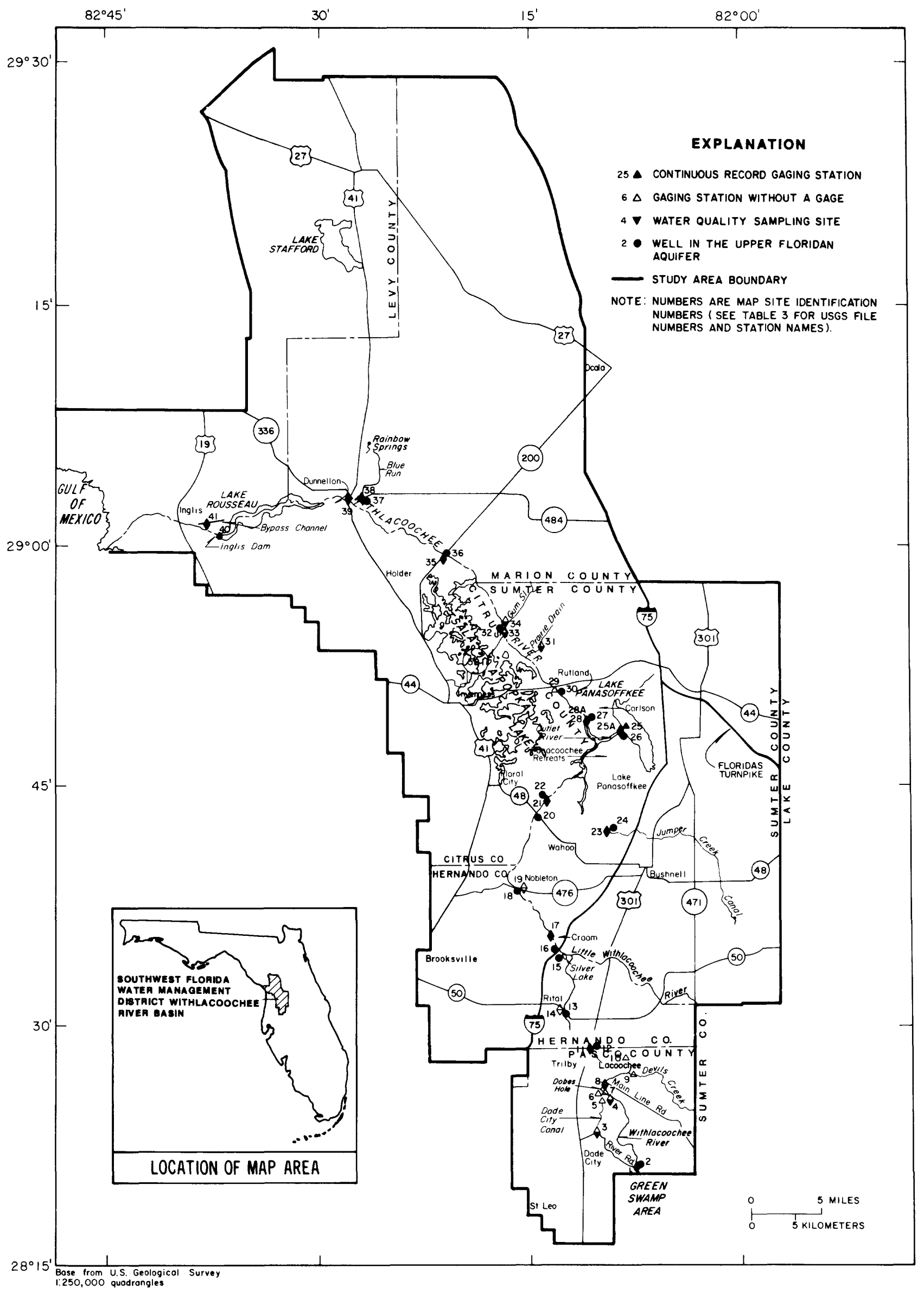

Figure 1.--Surface-water data-collection sites in the SWFWMD Withlacoochee River Basin and map numbers. 
1. Describe the mode of occurrence and quality of water in the Upper Floridan aquifer throughout the Basin.

2. Develop the proposed plans and scope for more detailed evaluation of the potential yield of the Upper Floridan aquifer in the various parts of the Basin.

Results of the Phase I investigation are published in U.S. Geological Survey Water-Resources Investigations Open-File Report 82-331 (Anderson and Laughlin, 1982). The most pertinent conclusions from that report are:

1. Transmissivity of the Upper Floridan aquifer is generally high throughout the SWFWMD Withlacoochee River Basin, though localized areas of lower transmissivity occur.

2. Quality of water in the Upper Floridan aquifer is generally excellent throughout the Basin, with the exception of some localized concentrations of iron and sulfate and the occurrence of brackish water in the coastal part of the Basin.

3. The Upper Floridan aquifer is recharged to some degree in all parts of the Basin except at or near the river or springs.

4. The total Basin may be generally delineated into several types of geohydrologic areas on the basis of relations between the Upper Floridan aquifer and the overlying sediments.

A need for additional investigation of the geohydrologic areas was identified for the subsequent Phase II investigation which was accomplished from October 1, 1980, through September 30, 1982. The major objective of Phase II was to achieve a better understanding of the several geohydrologic areas in the SWFWMD Withlacoochee River Basin in terms of how they are discharged, recharged, and interrelated, in order to conceptualize the longterm effects of ground-water development in the various areas.

Data collection for Phase II was originally limited to reconnaissance test drilling in the surficial aquifer and the confining beds overlying the Upper Floridan aquifer in the management area. Severe drought conditions, however, occurred during 1981 and some of the planned data-collection activities in the Basin were curtailed to allow documentation of record, or near-record, low-flow conditions. This report presents results of the phase II investigation (1) to better define the geohydrologic areas, and (2) to describe low-flow conditions. It presents drilling logs from the testdrilling reconnaissance; delineation of recharge areas and description of geohydrologic areas; and data, photographs, and descriptions for low-flow conditions.

\section{ENVIRONMENTAL SETTING}

The Withlacoochee River Basin, defined as a water-management area by the SWFWMD, occupies about $2,030 \mathrm{mi}^{2}$, and is very nearly the same size as the topographic drainage basin (about 2,000 $\mathrm{mi}^{2}$ of the Withlacoochee River. The two areas differ in that the SWFWMD Basin encompasses areas that, although not in the topographic basin, are from a ground-water standpoint hydrologically part of the SWFWMD Basin. The topographic basin also 
includes part of the SWFWMD Green Swamp Basin, which is another watermanagement area to the south and east of the SWFWMD Withlacoochee River Basin. Surface inflow from the Green Swamp Basin to the Withlacoochee River Basin is measured at station 1, in figure 1. The relation of the topographic drainage basin to the two SWFWMD management areas is shown in figure 2.

The parts of this report concerned with introductory material and with geohydrologic areas relate to the SWFWMD water-management area, which herein is referred to as the SWFWMD Withlacoochee River Basin, the SWFWMD Basin, or the Basin. The parts that are concerned with low-flow conditions relate to the topographic drainage basin of the Withlacoochee River, which herein is referred to as the Withlacoochee River basin, or the basin. Relative to the topographically defined basin, the "upper basin" denotes the part upstream from Nobleton, and the "low basin" denotes the part downstream from Nobleton (figs. 1 and 2).

\section{Climate}

The climate in the SWFWMD Withlacoochee River Basin is humid subtropical. Rainfall records (National Oceanic and Atmospheric Administration, 1931-78) for weather stations at St. Leo in Pasco County, Inverness in Citrus County, and Ocala in Marion County indicate average annual rainfalls of 55.54, 55.04, and 53.48 inches, respectively. These average rainfalls are considered representative of rainfall in the SWFWMD Basin. Most years have a pronounced rainy season, from June to October, when more than 60 percent of the total annual rainfall occurs. The mean monthly temperatures range from about $60^{\circ} \mathrm{F}$ for January to about $82^{\circ} \mathrm{F}$ for August.

Evapotranspiration may consume more than 70 percent of the average annual rainfall. For example, Pride and others (1966) report evapotranspiration losses of 34.5 to 39.1 inches from an investigation of the Green Swamp area which is adjacent to the southeast part of the Basin.

\section{Physiography and Drainage}

The majority of the SWFWMD Withlacoochee River Basin area is in the Central Highlands topographic division of Cooke (1945); a smaller coastal part of the Basin is in the Gulf Coastal Lowlands division. White (1970) further subdivides the part of the Basin within the Central Highlands into seven landform areas. These are, in general order of increasing altitude, the Tsala Apopka Plain; the Western Valley; the Lake and Sumter Uplands; and the Cotton Plant Ridge, Fairfield Hills, and Brooksville Ridge (fig. 3 ). Land surface altitudes range from sea level, in part of the Gulf Coastal Lowlands, to as high as 300 feet on the Brooksville Ridge at one location in the southwest part of the Basin.

The most prominent topographic feature is the northerly trending Brooksville Ridge which occupies most of the western side of the SWFWMD Basin. It is breached by the Withlacoochee River at Dunnellon Gap, about midway along the west side of the Basin. The Brooksville Ridge is an extensive, internally drained, karst terrane with high local relief. In contrast, the flat, low-lying Tsala Apopka Plain parallels the Brooksville Ridge in the south half of the Basin (fig. 3). The Western Valley landform lies immedi ately east of the Brooksville Ridge and the Tsala Apopka Plain. In the north half of the Basin, the Western Valley is a terrane of intermediate 


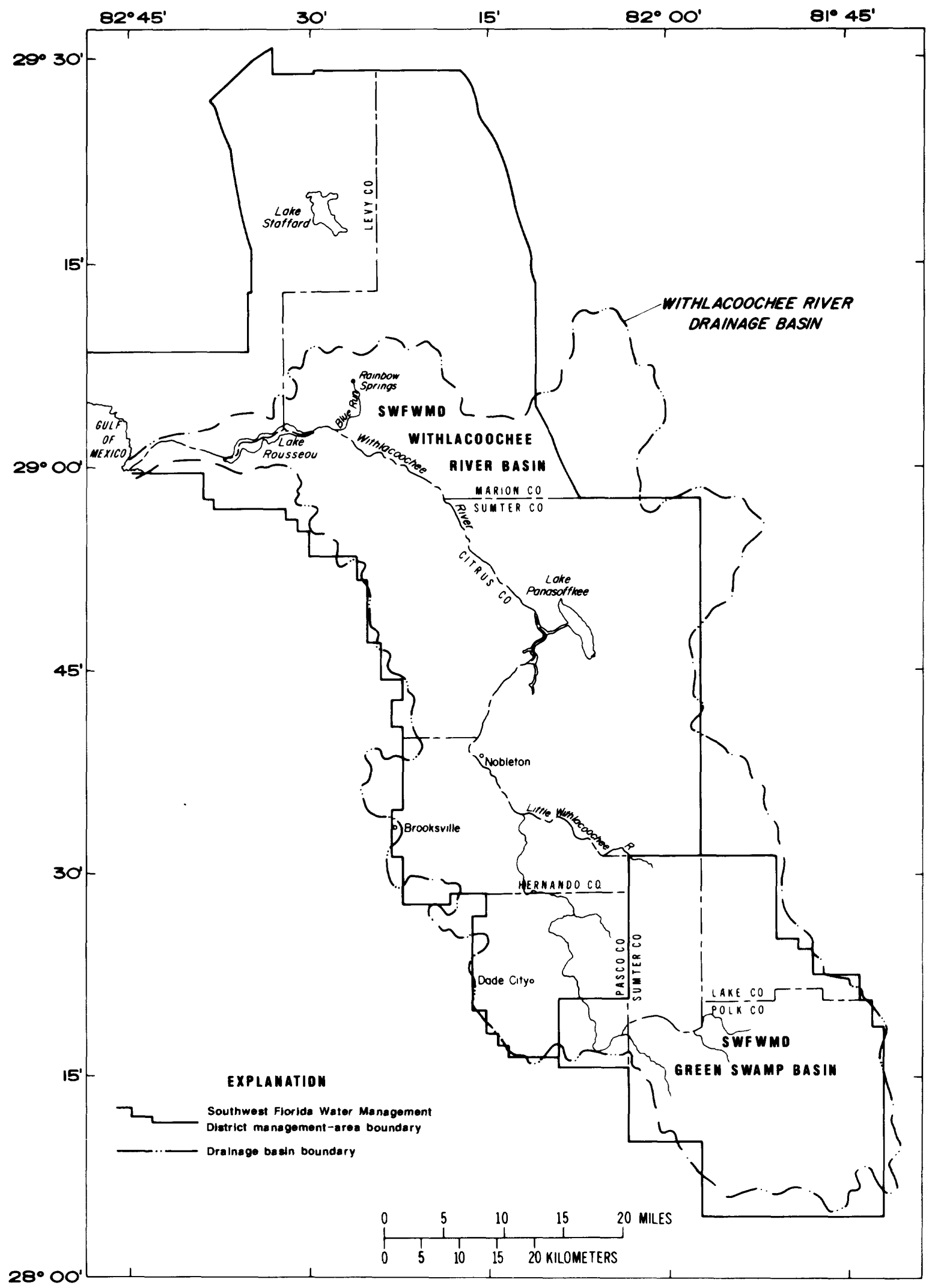

Figure 2.--Relation of SWFWMD Withlacoochee River Basin and Green Swamp basin management areas to the Withlacoochee River drainage basin. 


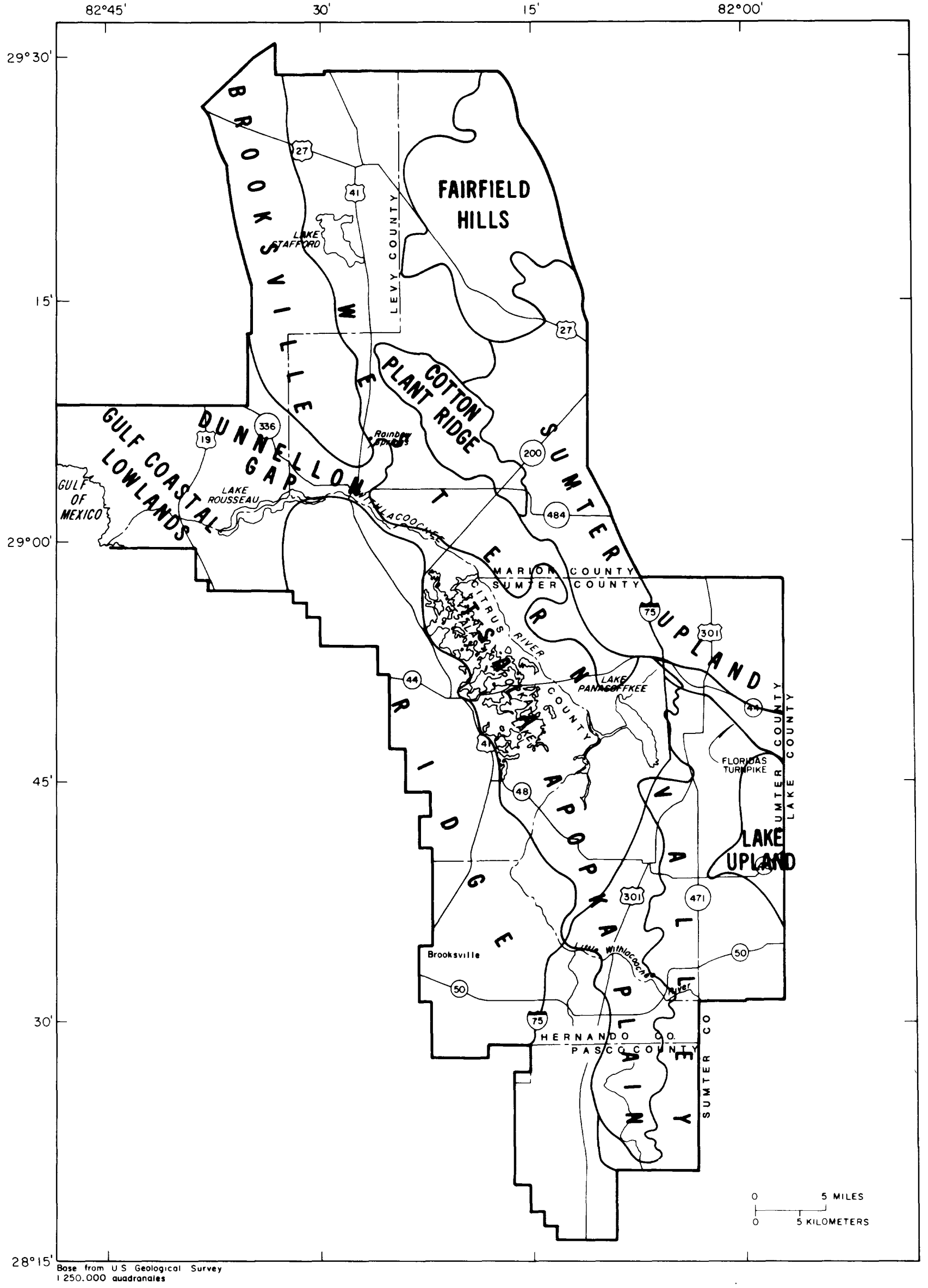

Figure 3.--Landforms in the SWFWMD With1acoochee River Basin.

6 
altitude and relief between the Brooksville Ridge and the Cotton Plant Ridge and Fairfield Hills landforms. In the south half of the Basin, the Western Valley landform is an intermediate surface that separates the Tsala Apopka Plain from the Lake and Sumter Uplands.

Practically all of the SWFWMD Withlacoochee Basin is drained by the Withlacoochee River and its tributary streams. The Withlacoochee River enters the south part of the SWFWMD Basin in Pasco County and flows northerly along the edge of the Brooksville Ridge to about the Citrus-Hernando County line, thence northeasterly to about the middle of the Tsala Apopka Plain, and thence north-northwesterly to near Dunnellon where its course turns west toward the Gulf of Mexico. In general, this stream system drains all of the Tsala Apopka Plain landform and parts of the Western Valley and Lake and Sumter Uplands landforms in the southern half of the Basin, and most of the area west of Dunnellon. Most of the remainder of the SWFWMD Basin is internally drained or has poorly developed surface drainage.

The largest bodies of surface water in the Basin are Lake Panasoffkee, Lake Rousseau, and the complex of interconnected lakes and wetlands that forms Tsala Apopka Lake. The largest spring is Rainbow Springs, a first magnitude spring, that discharges to the Withlacoochee River by way of Blue Run near Dunellon.

\section{Geohydrology}

The general stratigraphy, lithology, and water-bearing properties of the geologic units in the SWFWMD Withlacoochee River Basin are shown in table 1. The oldest geologic formation penetrated by potable water wells in the Basin is the Avon Park Formation (Miller, 1986) of middle Eocene age. The Avon Park, along with the overlying Ocala Limestone of late Eocene age; the Suwannee Limestone of Oligocene age; the Tampa Limestone of early Miocene age; and the lower limestone part of the Hawthorn Formation of middle Miocene age comprise, in ascending order, the Upper Floridan aquifer in the Basin.

The formations that comprise the Upper Floridan aquifer crop out in various areas of the SWFWMD Basin. Where these limestones are not exposed, they are covered with undifferentiated deposits of sand and clay that are more than 100 feet thick in some parts of the Basin. These deposits, which range in age from late Miocene to Holocene, are breached in many places by sinkholes. The thickest of these deposits are the Alachua Formation of Pliocene age, and the parts of the Hawthorn Formation that are not hydraulically connected with underlying formations (Anderson and Laugh1in, 1982). The Alachua Formation occurs in parts of Levy, Marion, Citrus, and Hernando Counties. The Hawthorn Formation in the Basin is restricted almost entirely to Pasco, Hernando, and Marion Counties with some interfingering with the Alachua Formation in southern Citrus County.

Yields from wells in the Upper Floridan aquifer, which is virtually the sole source of large ground-water supplies in the Basin, generally are high. Anderson and Laughlin (1982) report specific capacity data for 13 wells in the Basin to range from 1.5 to 640 (gal/min)/ft (gallons per minute per foot) of drawdown. Specific capacities for 8 of these 13 wells are greater than 100 (gal/min)/ft. Yields from wells in younger geologic materials generally are much lower. Sandy zones in the undifferentiated deposits overlying the Upper Floridan aquifer will., where saturated, yield sma11 (10 gal/min or less) to moderate $(10-50 \mathrm{gal} / \mathrm{min})$ quantities of water. 
Table 1,--General stratigraphy and water-bearing properties of the Upper Floridan aquifer and overlying unconsolidated deposits

[Modified from Anderson and Laughlin, 1982]

\begin{tabular}{|c|c|c|c|c|c|}
\hline System & Series & Formation & $\begin{array}{l}\text { Thickness } \\
\text { (feet) }\end{array}$ & Lithology & Water-bearing properties \\
\hline Quaternary & $\begin{array}{l}\text { Holocene } \\
\text { and } \\
\text { Pleistocene }\end{array}$ & $\begin{array}{l}\text { Alluvium } \\
\text { and } \\
\text { terrace }\end{array}$ & $0-50$ & Chiefly sand and clay. & $\begin{array}{l}\text { Yields small quantities } \\
\text { of water to shallow } \\
\text { wells. }\end{array}$ \\
\hline \multirow{6}{*}{ Tertiary } & Pliocene & $\begin{array}{l}\text { Alachua } \\
\text { Formation }\end{array}$ & $0-66$ & $\begin{array}{l}\text { Chiefly phosphatic sand } \\
\text { and clay. }\end{array}$ & $\begin{array}{l}\text { Yields small to moderate } \\
\text { quantities of water to } \\
\text { shallow wells. }\end{array}$ \\
\hline & \multirow[t]{2}{*}{ Miocene } & $\begin{array}{l}\text { Hawthorn } \\
\text { Formation }\end{array}$ & $0-140$ & $\begin{array}{l}\text { Chiefly interbedded } \\
\text { sand, clay, and lime- } \\
\text { stone and sandy phos- } \\
\text { phatic limestone and } \\
\text { marl. }\end{array}$ & $\begin{array}{l}\text { Yields small to moderate } \\
\text { quantities of artesian } \\
\text { and nonartesian water. } \\
\text { Acts as confining layer } \\
\text { for underlying artesian } \\
\text { water. Lower limestone } \\
\text { part is upper part of } \\
\text { Floridan aquifer system. }\end{array}$ \\
\hline & & $\begin{array}{l}\text { Tampa } \\
\text { Limestone }\end{array}$ & $0-100$ & $\begin{array}{l}\text { Limestone with sands, } \\
\text { silts, and clay. Con- } \\
\text { tains many solution } \\
\text { cavities in recharge } \\
\text { area. }\end{array}$ & $\begin{array}{l}\text { Yields large quantities } \\
\text { of water. }\end{array}$ \\
\hline & Oligocene & $\begin{array}{l}\text { Suwannee } \\
\text { Limestone }\end{array}$ & $0-200$ & $\begin{array}{l}\text { Limes tone containing } \\
\text { many solution cavities. }\end{array}$ & $\begin{array}{l}\text { Yields moderate quan- } \\
\text { tities of water but } \\
\text { generally less than } \\
\text { Eocene Formations. }\end{array}$ \\
\hline & \multirow[t]{2}{*}{ Eocene } & $\begin{array}{c}\text { Ocala } \\
\text { Limestone }\end{array}$ & $0-200$ & $\begin{array}{l}\text { Upper part chiefly } \\
\text { chalky fossiliferous } \\
\text { limestone. Lower part } \\
\text { chiefly calcitic lime- } \\
\text { stone. }\end{array}$ & $\begin{array}{l}\text { One of the most produc- } \\
\text { tive formations of the } \\
\text { Floridan. Upper part } \\
\text { more productive than } \\
\text { lower part. Contains } \\
\text { many solution cavities. }\end{array}$ \\
\hline & & $\begin{array}{l}\text { Avon Park } \\
\text { Formation }\end{array}$ & $900-1,500$ & $\begin{array}{l}\text { Cream-colored to brown } \\
\text { chalky limestone and } \\
\text { dolomite. Contains } \\
\text { gypsum and chert. }\end{array}$ & $\begin{array}{l}\text { Yields moderate to large } \\
\text { quantities of water } \\
\text { to wells. }\end{array}$ \\
\hline
\end{tabular}

The Upper Floridan aquifer contains water under unconfined to confined conditions in the SWFWMD Basin. The potentiometric surface of the Upper Floridan aquifer for May 1979 is shown in figure 4. The highest potentiometric-surface altitudes are in the southeastern and southern parts of the Basin. The general direction of ground-water movement in this area is from east to west. In the northern half of the Basin, ground-water movement generally is to the south; however, two small closed-contour potentiometricsurface highs near Dunnellon modify the flow system in this area. The ground-water basins are delineated and the general flow directions in the Upper Floridan aquifer are shown in figure 4.

Areas of recharge to the Upper Floridan aquifer in the Basin, as delineated by Anderson and Laughlin (1982), are shown in figure 5. The areas of high recharge are areas from which little or no surface runoff occurs. These areas include all of the Brooksville Ridge and most of the other topographically high areas. The areas of moderate recharge are those areas where moderate surface runoff occurs. These areas include all of the Gulf 


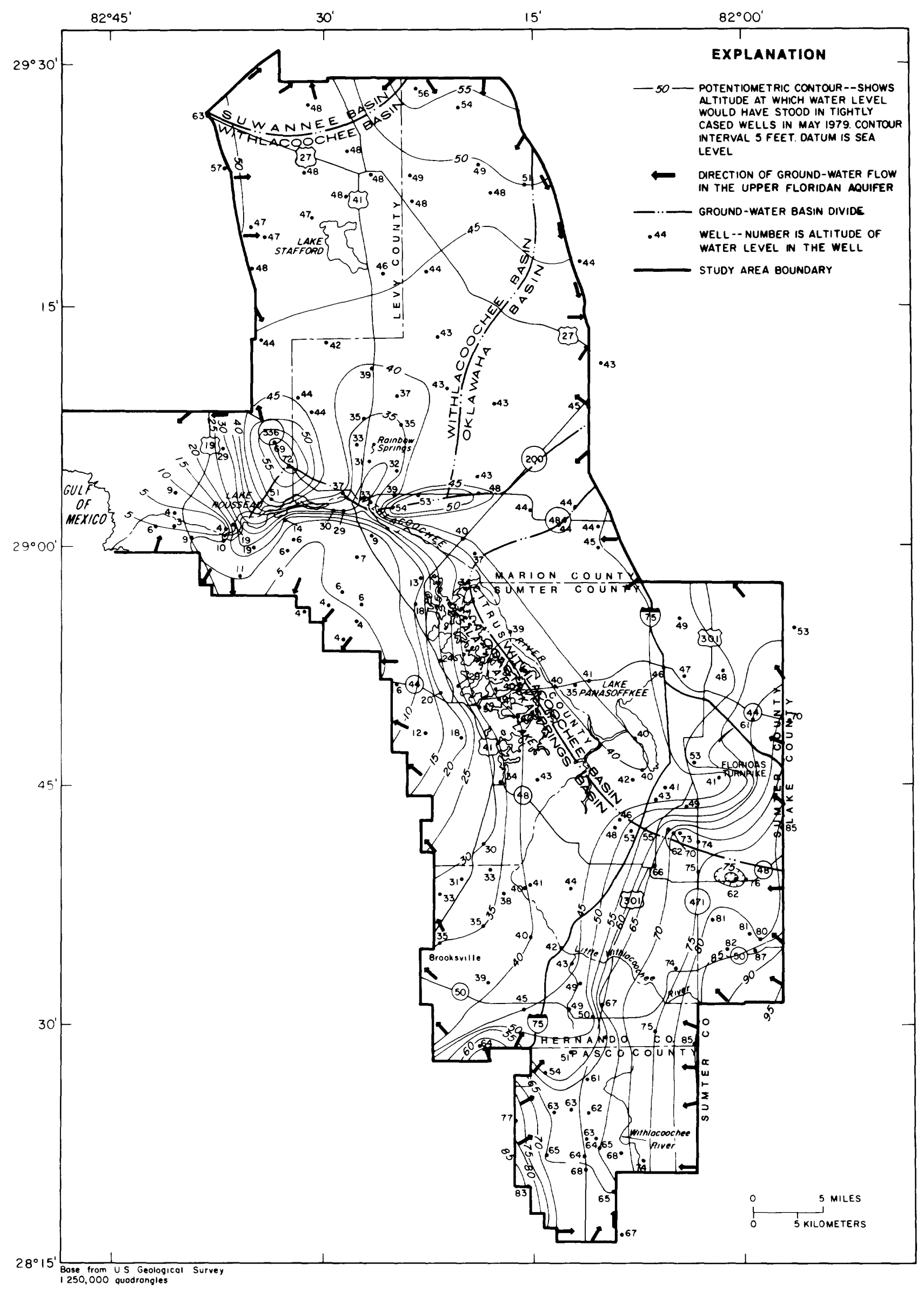

Figure 4.--Altitude of the potentiometric surface of the Upper Floridan aquifer in May 1979, general directions of ground-water flow, and locations of groundwater basins. 


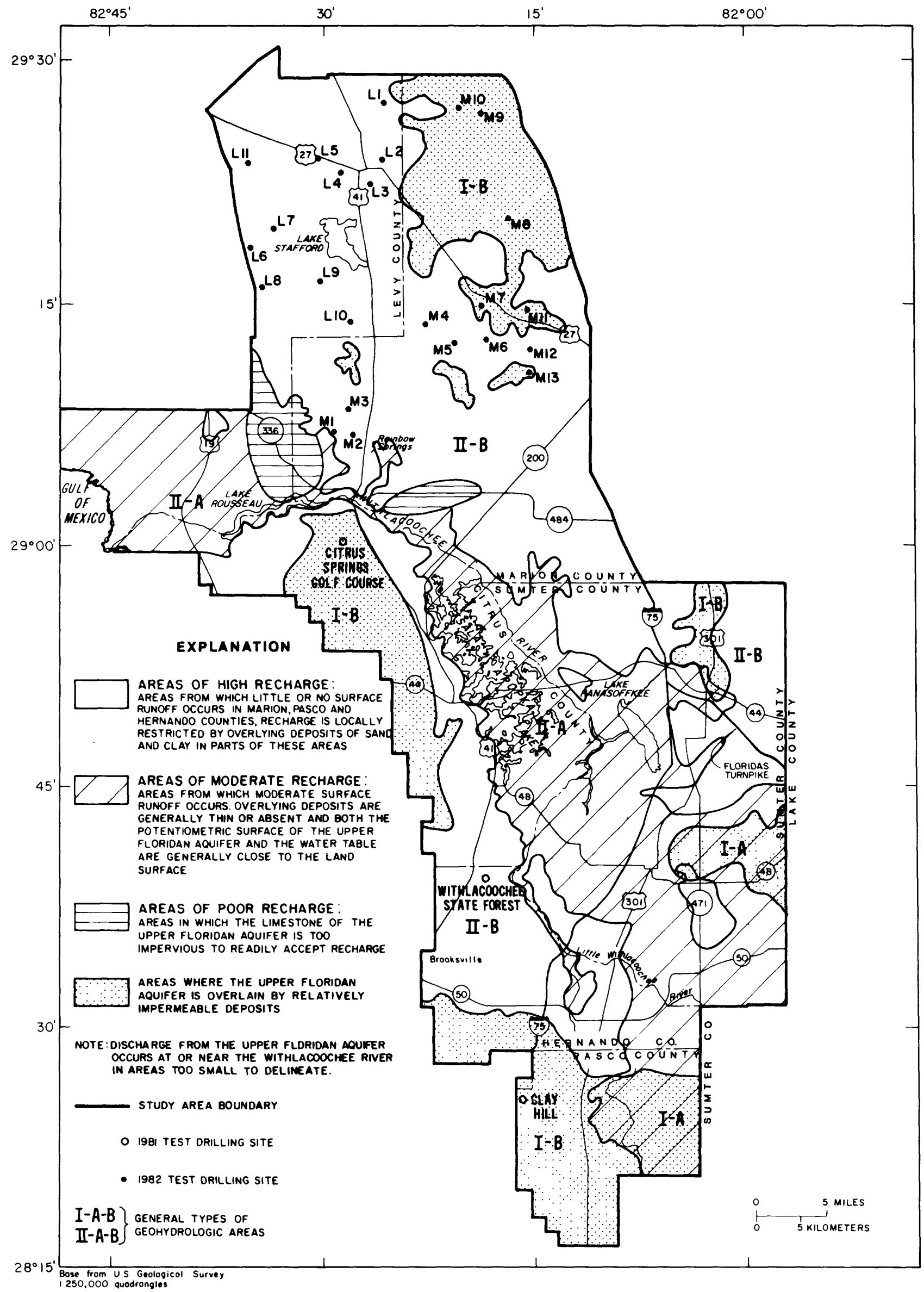

Figure 5.--Areas of recharge to the Upper Floridan aquifer. 
Coastal Lowlands and all of the Tsala Apopka Plain landform and some adjacent parts of the Western Valley landform. Ryder (1982, fig. 16) indicates that recharge may range from 9 to 20 inches per year in areas of high recharge and from 1 to 8 inches per year in areas of moderate recharge. The areas of poor recharge in the Basin are two areas that coincide with the closed-contour potentiometric-surface highs near Dunnellon. Here, the Upper Floridan aquifer has relatively low permeability, which does not allow for drainage, so recharge rates are low because there is less storage available in the aquifer.

The Upper Floridan aquifer is recharged to some degree in all parts of the SWFWMD Basin except in or near the river, springs, and spring runs. Total recharge is the sum of recharge that occurs within the Basin and subsurface inflow to the Basin from adjacent upgradient areas. About one-half of total recharge to the Basin is discharged into the Withlacoochee River and the remainder leaves the Basin as subsurface outflow at the eastern and western boundaries except a very small part that discharges across the northern boundary (Anderson and Laughlin, 1982).

Quality of water in the Upper Floridan aquifer generally is suitable for most purposes over most of the Basin. Fresh ground water usually occurs except in the area west of Dunnellon and in the coastal part of the Basin where chloride concentrations may exceed $250 \mathrm{mg} / \mathrm{L}$ (milligrams per liter). The total thickness of freshwater is unknown throughout most of the Basin but is in excess of 1,000 feet in the eastern and southeastern areas.

An understanding of hydrologic conditions, comparable to that developed for the Upper Floridan aquifer, is not available for the materials that overlle the Upper Floridan aquifer in the SWFWMD Withlacoochee River Basin. For example, detailed knowledge of the distribution of the unconsolidated sediments and of how they function in regard to both their confinement of, and transmission of recharge to, the Floridan aquifer is basically lacking. In this general regard, Anderson and Laughlin (1982) indicate:

The mode of occurrence of water in the Upper Floridan aquifer is controlled by the presence or absence of unconsolidated rocks over the limestone and, where present, the hydraulic conductivity of the unconsolidated rocks. Where the limestone is exposed or covered by unconsolidated rocks too thin to contain a shallow aquifer or too pervious to confine water under pressure significantly greater than atmospheric, water in the Upper Floridan aquifer is unconfined and effectively under water-table conditions.

In areas where the unconsolidated rocks contain a water-table aquifer that is effectively separated from the Upper Floridan aquifer by confining beds, water in the Upper Floridan aquifer can be either confined or unconfined. If the potentiometric surface of the Upper Floridan aquifer is above the bottom of the confining beds, water in the aquifer is confined. However, where the potentiometric surface of the Floridan aquifer is below a confining layer that can support an overlying aquifer or aquifers which are perched (hydraulically isolated from the Floridan) water in the Floridan is considered unconfined (under water-table conditions). 


\section{GEOHYDROLOGIC AREAS}

The SWFWMD Withlacoochee River Basin can be delineated into several types of geohydrologic areas based on the mode of occurrence of water in the Upper Floridan aquifer and the hydraulic, or geohydrologic, relations between the Floridan and the overlying unconsolidated materials. These relations control factors, such as the relative degree of confinement of the Upper Floridan, degree and type of surface drainage, and the altitude of the potentiometric surface of the Upper Floridan aquifer in relation to the water table in the overlying unconsolidated materials. The combined influences of these factors control the occurrence and distribution of recharge and discharge for the Upper Floridan aquifer under the generally unstressed conditions that prevailed in the Basin (Anderson and Laughlin, 1982). A comprehensive understanding of these factors is important to efficient development and management of the water resources of the Basin because large withdrawals of ground water from different geohydrologic areas may result in widely differing effects on the total hydrologic and surface environments, initially in the area of withdrawals and potentially extending to adjacent and more distant areas.

Anderson and Laughlin (1982) introduced the concept of geohydrologic areas in the SWFWMD Basin and generally delineated the areas in a map from which figure 6 is adapted. The initial criterion used in preparation of figure 6 was whether or not the potentiometric surface of the Upper Floridan aquifer is above the top of the aquifer. This was approximated by comparing the potentiometric surface in May 1979 with the top of the Upper Floridan aquifer as depicted by Buono and Rutledge (1978). Then the genera1 1ithology of overburden sediments, where present, was added by use of data from Knapp (1978), Scott (1978), and Deuerling and MacGill (1981).

Information shown in figures 4,5 , and 6 may be used to generalize several types of geohydrologic areas, as follows:

I. Areas in which the Upper Floridan aquifer is overlain by relatively impermeable deposits.

A. Wetlands.--These are areas of moderate runoff in which the potentiometric surface of the Upper Floridan aquifer is near land surface. Some recharge occurs across the confining beds, but the Upper Floridan aquifer is virtually filled to capacity at existing hydraulic gradients.

B. Well drained areas.--These are largely karst areas with no external surface drainage. The water table in the overlying deposits may be relatively close to land surface and high in relation to the potentiometric surface which may at times occur below the top of the Upper Floridan aquifer. However, considerable recharge does occur to the Upper Floridan aquifer, apparently in those topographically low areas where confining beds have been breached by sinkholes. 


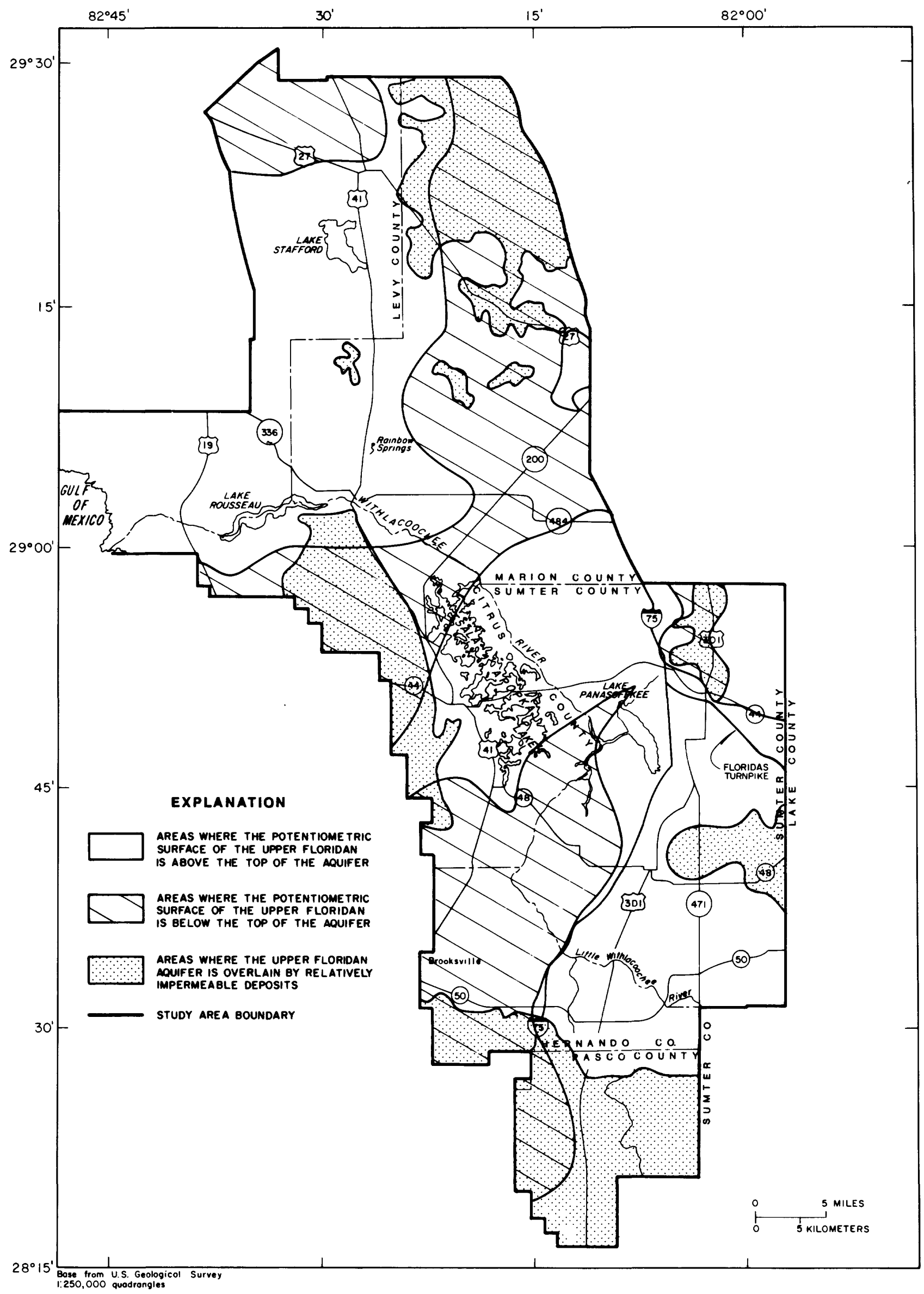

Figure 6.--Relation between the altitudes of the potentiometric surface and the top of the Upper Floridan aquifer, May 1979, and distribution of relatively impermeable deposits. 
II. Areas in which the Upper Floridan aquifer is overlain by leaky confining beds or in which confining beds are absent.

A. Wetlands.--Areas of moderate runoff in which the potentiometric surface of the Upper Floridan aquifer is at or near land surface. The Upper Floridan aquifer is full and rejects water to evapotranspiration and surface runoff during periods of high rainfall. Some recharge, however, occurs on an areal, and possibly seasonal, basis.

B. Well drained karst areas.--These include outcrop areas where the water table fluctuates in the limestones of the Upper Floridan aquifer, and areas where the Upper Floridan is overlain by predominantly sandy materials. In the latter case, there is usually a water table at some depths in the sands, but above the potentiometric surface of the Upper Floridan aquifer. These are the areas where maximum recharge is probably occurring under present (unstressed) conditions in the Basin.

Areas where the potentiometric surface of the Upper Floridan aquifer is above land surface are discharge areas. They are not included in the above descriptions because areas of discharge in the SWFWMD Withlacoochee River Basin are restricted to those around the springs and along the river, and are too small to delineate (Anderson and Laughlin, 1982).

The four types of geohydrologic areas described above are hereinafter referred to by their respective numeral-letter designation; that is, as areas IA, IB, IIA, or IIB. Their distribution is shown in figure 7 . It was apparent, in developing descriptions of these areas, that more understanding of area IB was needed before formulating a conceptualization of effects of ground-water withdrawals. Area IB is largely composed of closed-basin (karst) terranes that are developed on generally clayey sediments that overlie the Upper Floridan aquifer. Well drained surface conditions are evidence of recharge to the Floridan. However, the water table in the overburden sediments is relatively close to the land surface in many parts of these areas, as indicated by the occurrence of numerous small lakes whose levels are high in relation to the potentiometric surface of the Upper Floridan aquifer. The topographically higher parts of these areas probably contain perched water-table conditions; that is, an unsaturated zone occurs between the base of the water-table saturated zone in the surficial materials and the unconfined potentiometric surface in the Upper Floridan aquifer. If this perched water-table condition occurs on an areal basis, then the Upper Floridan and the overburden materials should be treated as two separate unconfined aquifers for conceptual purposes. However, if the perched conditions only occur in small, localized areas (that is, individual lake basins), they may then be disregarded and the Upper Floridan aquifer may be treated as a single unconfined aquifer for conceptual purposes. Reconnaissance test drilling was thus scheduled to explore the occurrence and areal extent of perched water-table conditions in geohydrologic areas IB. 


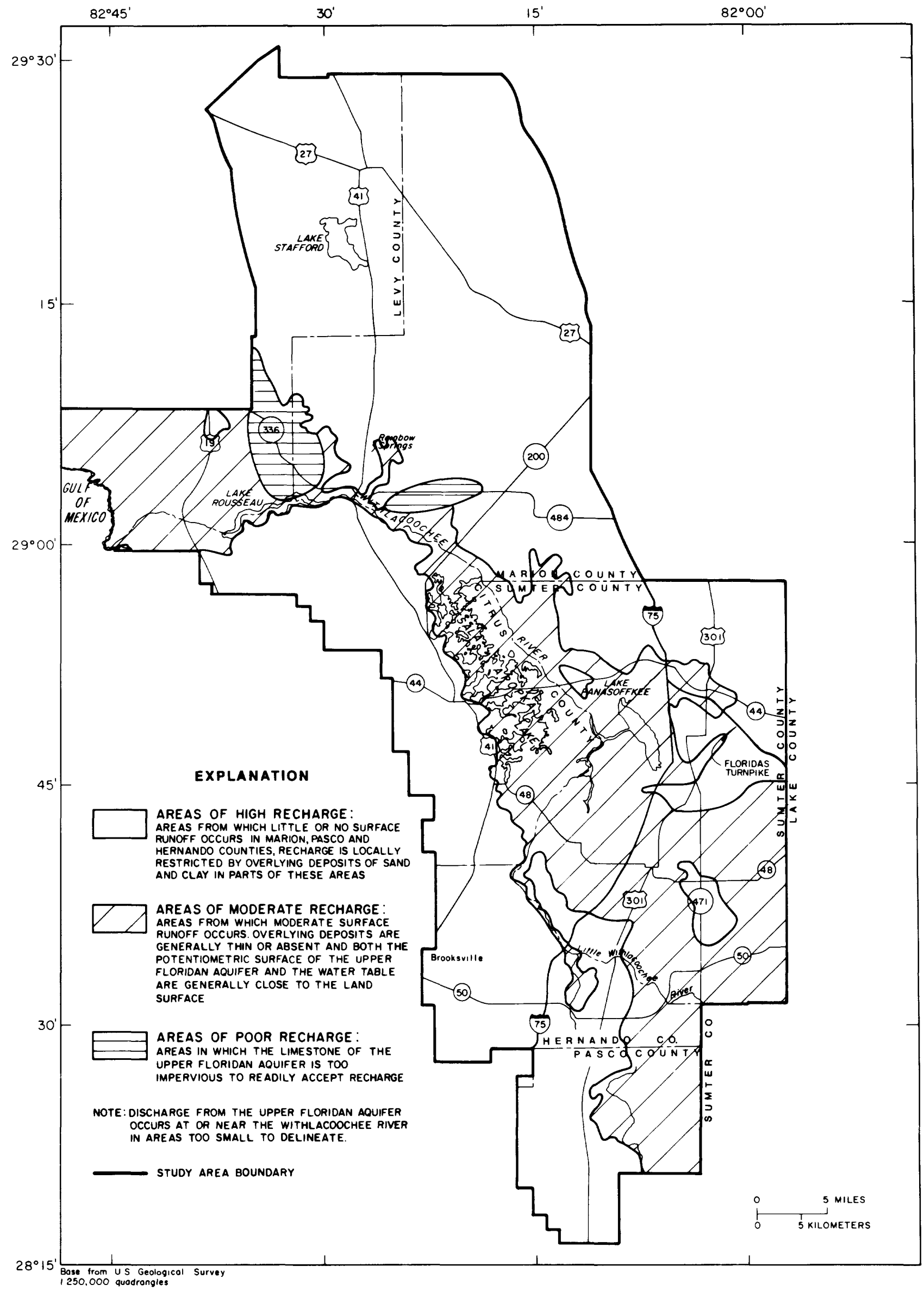

Figure 7.--General distribution of geohydrologic areas. 


\section{RESULTS OF TEST DRILLING \\ Test Drilling. 1981}

All test drilling was by use of a hollow-stemmed power auger that allowed collection of lithologic samples with a split-spoon core barrel. This drilling method also allowed installation of small-diameter casing for measurement of water levels at selected depth intervals. Initially, three sites were chosen for test drilling to investigate the perched water-table conditions during 1981. Those sites are Withlacoochee State Forest, Citrus Springs Golf Course, and Clay Hill (fig. 7), as discussed below.

\section{Withlacoochee State Forest}

Three test holes were drilled at this site in northeast Hernando and southeast Citrus Counties (fig. 8). Here, at the Environmental Center of the Withlacoochee State Forest, there is an existing water well for which drilling records indicate the top of the Upper Floridan aquifer to be at about altitude 65 feet above sea level and the water level to be at about altitude 30 feet. This Upper Floridan aquifer well is intermediate in distance between Buck Lake, about one-half mile to the north, and McKethan Lake to the south.

Test hole 1A-81 (fig. 8) was drilled near the site of the existing water we11.

\section{Drilling log--test hole $1 \mathrm{~A}-81$}

(Land-surface datum 97 feet)

Depth (feet)

$\begin{array}{cl}0-6 & \text { silt, clayey, medium brown } \\ 6-10 & \text { limestone, white } \\ 10-15 & \text { limestone, white, cherty, } \\ \text { some phosphate } \\ 15-20 & \text { limestone, white }\end{array}$

Continued to drill to 40 feet, little return.

Note that the existing water well near test hole $1 \mathrm{~A}-81$ had penetrated limestone (Upper Floridan aquifer) at about 35 feet below land surface (a1titude 65 feet), but that limestone was encountered at a depth of 6 feet below land surface (altitude 90 feet) in test well 1A-81. Drilling of test hole 1A-81 was stopped at a depth of 40 feet without having penetrated to the zone of saturation.

At time of drilling test hole $1 \mathrm{~A}-81$, the water level in the nearby water well was at about altitude 30 feet which represented the water table. This altitude for the water table correlated with the water level in Buck Lake (which was almost dry at that time), but was about 30 feet lower than the water leve1 in McKethan Lake.

Test hole 1B-81 was subsequently drilled about one-half mile to the north of Buck Lake. 


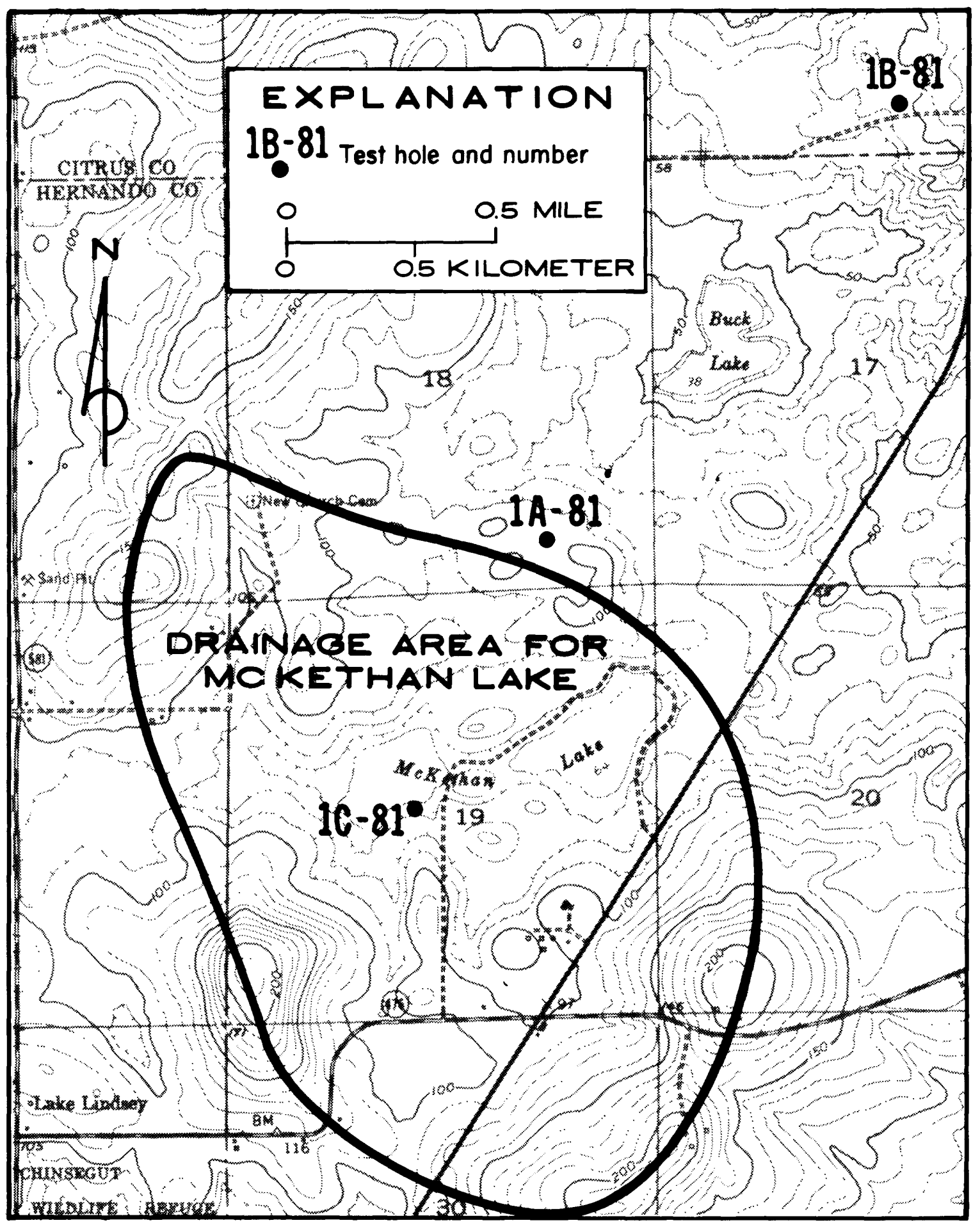

Base from U.S. Geological Survey

$1: 24,000$ Quadrangles

Figure 8.--Locations of test holes, Withlacoochee State Forest site. 
Drilling log--test hole $1 \mathrm{~B}-81$

(Land-surface datum 95 feet)

\title{
Depth (feet)
}

$\begin{array}{cl}0-25 & \text { sand, fine to medium, light brown to white } \\ 30-40 & \text { sand, coarse to medium, white } \\ 45-75 & \text { sand, fine silty, white } \\ 80-130 & \text { sand, fine, very silty, white } \\ 130-132 & \text { limestone }\end{array}$

The Upper Floridan aquifer (1imestone) was not encountered until depth of about 130 feet below land surface (altitude -35 feet) in this test hole. Note also that no confining materials were penetrated in the approximately 130 feet of overburden on the Upper Floridan aquifer. Casing was not installed in test hole 1B-81, but altitude of the water table was estimated at about 30 to 35 feet during drilling.

McKethan Lake occupies a small, closed drainage basin, and its altitude was about 55 feet at the time that test hole 1C-81 was drilled on the southwest side of the lake.

\author{
Drilling log--test hole 1C-81 \\ (Land-surface datum 71 feet) \\ Depth (feet) \\ 5-15 sand, fine to medium, silty, light \\ brown to gray \\ 15-20 sand, fine to medium, gray, silty \\ white gray-green clay at bottom \\ 25-40 clay, brown to gray \\ 40-50 clay, white, plus limestone
}

The Upper Floridan aquifer (1imestone) was penetrated at a depth of about 50 feet below land surface (altitude 20 feet). About 25 feet of relatively tight clays overlie the Upper Floridan aquifer and.appear to hold the level of McKethan Lake at the higher altitude.

Two observation wells were installed at the site of test hole $1 \mathrm{C}-81$. One was screened in the lower part of the sandy material at depth of 23 feet; the water level was at about altitude 50 feet. The other was open to the Upper Floridan aquifer at a depth of 65 feet; its water level was at about altitude 30 feet. The potentiometric surface of the Upper Floridan aquifer occurs in the confining clay bed, which in turn, holds the level of McKethan Lake at relatively high altitudes. Here, at least locally, the Upper Florldan aquifer is confined, whereas it appears to be completely unconfined at the sites of test holes $1 \mathrm{~A}-81$ and $1 \mathrm{~B}-81$.

\section{Citrus Springs Golf Course}

One test hole site was drilled at Citrus Springs Golf Course in northcentral Citrus County (fig. 7). Land-surface altitude at the site is about 78 feet. A water well at the site. is reported to have penetrated the Upper 
Floridan aquifer at about altitude 50 feet; water level at time of test drilling was at about altitude 10 feet. There are no lakes in the general area.

One test hole (2-81) was drilled and cased at the site.

Drilling log--test hole 2-81

(Land-surface datum 78 feet)

Depth (feet)

5-15 sand, fine, brown

15-20 clay, light brown and white

20-25 1imestone

Drilled to 35 feet.

Two observation wells were installed. One was screened in the base of the surficial sand at a depth of 19 feet; water level was at depth 10 feet, or altitude 68 feet. The second was cased through the clay and open to a depth of about 35 feet (altitude 43 feet) in the Upper Floridan aquifer; there was no water in this observation well. Perched water-table conditions thus occur at the site. The surficial aquifer contains a saturated zone about 10 feet thick, and there appears to be an underlying unsaturated zone of about 40 to 45 feet thick in the Upper Floridan aquifer.

Clay Hill

The third and last site drilled during 1981 was at a topographically high area in northeast Pasco County that is locally known as Clay Hill (fig. 7). This topographic feature, rising to an altitude of about $300 \mathrm{feet}$, is the highest area in the SWFWMD Withlacoochee River Basin.

The drilling site is at about altitude 289 feet. The $\log$ for a nearby water well indicated the top of the Upper Floridan aquifer to be at about altitude 150 feet, and its water level to be at about altitude 100 feet. Jessamine Lake, less than a mile to the southwest, is at altitude 140 feet, or about 40 feet higher than the Upper Floridan aquifer potentiometric surface.

One test hole (3-81) was drilled at the site.

Drilling log--test hole 3-81

(Land-surface datum 189 feet)

Depth (feet)

$$
\begin{aligned}
5-20 & \text { sand, very fine, dark red } \\
25-45 & \text { sand, fine, silty, yellowish brown } \\
50-85 & \text { sand, fine, silty, light brown } \\
90-100 & \text { clay, brown } \\
105-110 & \text { clay, white with black stripes } \\
115 & \text { clay, white with limestone }
\end{aligned}
$$

The top of the Upper Floridan aquifer (1imestone) was penetrated at depth of 115 feet, or about altitude 174 feet. Test hole 3-81 was drilled 
to a total depth of 140 feet, or 25 feet into the limestone of the Upper Floridan aquifer. Three observation wells were then installed at the site (with screens at the 65- and 85-foot depth, and open to the limestone at 140 feet), but there was no water in any of the wells. Thus, the only water table at site 3-81 occurs in the Upper Floridan aquifer at depths of about 190 feet below land surface, based on the water level in the nearby well. In contrast, Jessamine Lake is some 40 feet higher than the Upper Floridan aquifer potentiometric surface. It is assumed to be perched on, or held up by, a localized clayey zone that does not occur at site 3-81.

\section{Test Drilling, 1982}

Twenty-four test holes were drilled by power auger in the northern part of the SWFWMD Basin in Marion and Levy Counties during 1982 (fig. 7). During drilling of these test holes, auger samples were collected and the approximate location of the water table (if penetrated) was noted. All holes except two, where problems were encountered, were drilled to the top of the Upper Floridan aquifer. However, split-spoon samples were not collected nor was casing installed for water-level measurements as had been done for the test holes that were drilled during 1981. Objectives were to develop area1 reconnaissance information on depth to top of the Upper Floridan aquifer, position of the water table in relation to the potentiometric surface or the top of the Upper Floridan aquifer, and lithology of the materials overlying the Upper Floridan aquifer. Six of the 24 test holes were drilled in areas that are mapped in type IB geohydrologic areas (fig. 7); the remainder were in areas mapped as type IIB geohydrologic areas. Test drilling results are summarized in table 2 .

\section{Summary of Test-Drilling Results}

During 1981 test drilling, two of the three sites were within type IB geohydrologic areas as mapped in figure 7; the third site (Withlacoochee State Forest) was partially in such an area. Perched water-table conditions were observed in the one test hole drilled at the Citrus Springs site where a saturated zone overlies a relatively shallow clay bed; there are no lakes in this area. Perched water-table conditions were observed at the other two sites only in the vicinity of a lake that appears to occupy a high position in relation to the potentiometric surface of the Upper Floridan aquifer.

During 1982 test drilling, perched water-table conditions were observed at only 2 of the total of 24 test-drilling sites. These two test holes (M-9, M-10) are in areas mapped as type IB geohydrologic areas; and one test hole $(M-10)$ is near a lake that appears to be perched in relation to the potentiometric surface of the Upper Floridan aquifer. Only a single water table was penetrated in each of the other 22 test holes; and in 21 of these, the water level was below the top of the limestone of the Upper Floridan aquifer (table 2).

\section{Conclusions on Results of Test Drilling}

Based on results of test drilling in 1981 and 1982, perched water-table conditions are localized to relatively small areas, such as individual lake basins, by discontinuous clay beds. Therefore, the Upper Floridan aquifer can be treated as an unconfined aquifer in the SWFWMD Withlacoochee River Basin; that is, the presence and effects of an overlying perched water-table 
Table 2. - - Summary of data for test holes drilled during 1982

\begin{tabular}{|c|c|c|c|c|c|c|c|}
\hline $\begin{array}{c}\text { Well } \\
\text { No. } \\
\text { (see } \\
\text { fig. 5) }\end{array}$ & $\begin{array}{l}\text { Alti- } \\
\text { tude } \\
\text { of } \\
\text { well } \\
\text { site } \\
\end{array}$ & $\begin{array}{l}\text { Depth } \\
\text { of we11 }\end{array}$ & $\begin{array}{l}\text { Depth } \\
\text { to } \\
\text { lime- } \\
\text { stone }\end{array}$ & $\begin{array}{c}\text { Material above } \\
\text { limestone }\end{array}$ & $\begin{array}{c}\text { Level } \\
\text { of } \\
\text { nearby } \\
\text { lake }\end{array}$ & $\begin{array}{l}\text { Water } \\
\text { table } \\
\text { above } \\
\text { lime- } \\
\text { stone? }\end{array}$ & Remarks \\
\hline$M-1$ & 65 & 66 & 66 & Silt, silty clay & 60 & No & \\
\hline$M-2$ & 95 & 120 & -- & Silt, silty sand & -- & No & \\
\hline$M-3$ & 100 & 105 & 95 & Silt, very fine sand & - - & No & \\
\hline$M-4$ & 80 & 22 & 20 & Silt, clay & - - & No & \\
\hline M-5 & 165 & 52 & 52 & Silt, clay & 135 & No & \\
\hline$M-6$ & 95 & 59 & 59 & Silt, sandy clay & - - & No & \\
\hline$M-7$ & 120 & 80 & -- & Silt, clay & - - & No & \\
\hline M-8 & 100 & 31 & 31 & Silt, clay & - - & No & \\
\hline M-9 & 145 & 112 & 112 & Silt, sand, clay & - - & Yes & 1 \\
\hline$M-10$ & 86 & 72 & 72 & Silty sand & 75 & Yes & 2 \\
\hline$M-11$ & 160 & 37 & 37 & Silty sand & -- & No & \\
\hline$M-12$ & 95 & 59 & 59 & Silty clay & - - & No & \\
\hline$M-13$ & 75 & 21 & 21 & Silt & -- & No & \\
\hline L-1 & 100 & 61 & 61 & Silt, fine sand & -- & No & \\
\hline $\mathrm{L}-2$ & 100 & 15 & 8 & Silty sand & -- & No & \\
\hline$L-3$ & 75 & 40 & 37 & Silt, fine sand & - - & No & \\
\hline$L-4$ & 72 & 4 & 4 & Silt & - - & No & \\
\hline L-5 & 67 & 35 & 31 & Silt, sand & - - & Yes & 3 \\
\hline$L-6$ & 85 & 120 & 45 & Silt & - - & No & \\
\hline L-7 & 90 & 50 & 35 & Silt, sand & -- & No & \\
\hline$L-8$ & 80 & 100 & 85 & Silt, silty sand & - - & No & \\
\hline L-9 & 70 & 50 & 37 & Silt & - - & No & \\
\hline L-10 & 62 & 35 & 21 & Silty sand & - - & No & \\
\hline L-11 & 110 & 110 & 75 & Silt, sand & - - & No & \\
\hline
\end{tabular}

\footnotetext{
${ }^{1}$ Perched water table at 7 feet below land surface--another water table at 100 feet below land surface.

${ }^{2}$ Shallow water table at 4 feet below land surface--another water table at 100 feet below land surface.

${ }^{3}$ No perched water table observed.
}

aquifer can be disregarded for purposes of areal conceptualization. Negating the effects of confining beds also simplifies the previous assumptions in regard to types of geohydrologic areas that occur in SWFWMD Basin by reducing the number from four to two; that is, (1) we11 drained areas, or areas with no external surface runoff, and (2) wetlands, or areas with poorly developed surface drainage. These two types of areas are, respectively, those areas shown and described in figure 5 as (1) areas of high recharge, and (2) areas of moderate recharge. Thus, for conceptual purposes, the remainder of this report will treat the SWFWMD Basin as being comprised of the two major types of recharge areas that were mapped by Anderson and Laughlin (1982). Note that a third type of area (poor recharge areas) is also delineated in figure 5. However, these are considered to be poor areas for development of large ground-water supplies because of low 
transmissivity in the Upper Floridan aquifer, so they are not further discussed. Another conclusion based on drilling results is that, when viewed on a local scale, the top of the Upper Floridan aquifer is a highly irregular surface.

\section{CONCEPTUALIZATION OF LONG-TERM EFFECTS OF GROUND-WATER DEVELOPMENT}

Under natural conditions, and on a long-term basis, recharge and discharge for an aquifer are virtually equal; the aquifer is in a state of dynamic equilibrium, wherein seasonal, or annual, differences in recharge and discharge are reflected by variations in storage in the aquifer. Pumping of ground water disturbs this natural equilibrium by withdrawing water from aquifer storage. This creates a gradient toward the pumping wel1 which may result in (a) decrease in natural discharge of the aquifer by decreasing the gradient toward areas of natural discharge, and (b) increase in recharge to the aquifer by increasing the vertical gradient between the land surface and the potentiometric surface.

The source of water withdrawn by wells is from (1) a decrease in storage in the aquifer, (2) a reduction of the previous discharge from the aquifer, (3) an increase in the recharge to the aquifer, or (4) a combination of these changes (Theis, 1940, p. 277). The decrease in discharge from the aquifer plus the increase in. recharge is termed capture (Lohman, 1972, p. 3). Thus, when withdrawal is imposed, the head in an aquifer will continue to decline until (or unless) the rate of withdrawal is equaled by the capture. In a case where the rate of sustained withdrawal continues to exceed the capture, heads in the aquifer will continue to decline and a condition of mining of ground water occurs. In a case where the withdrawal is balanced by the capture, a condition of dynamic equilibrium occurs. Capture is thus a most important factor in development of ground water supplies; sustained yield is, in effect, limited by capture and cannot exceed it (Bredehoeft and others, 1982).

Knowledge of the distribution and function of geohydrologic areas is important to water management because large and sustained withdrawals of ground water can result in significantly different results, depending on location of these withdrawals in relation to geohydrologic areas. This section of the report thus conceptualizes the effects of ground-water development in the two major types of geohydrologic areas; that is, (1) areas of high recharge, and (2) areas of moderate recharge, as shown in figure 5.

For conceptual purposes, each of the two types of geohydrologic areas is discussed separately, and it is assumed that a large, but unspecified, withdrawal of ground water is developed from a well field in the Upper Floridan aquifer in an inner part (away from boundaries) of each type area. It is also assumed that:

(a) Transmissivity and storage properties of the Upper Floridan aquifer, and the degree of hydraulic connection between the Upper Floridan aquifer and the overburden materials (where present) generally are uniform throughout the SWFWMD Basin. 
(b) The ground water withdrawn is consumptively used or exported from the area; that is, no significant part of the withdrawal is returned as recharge to the Upper Floridan aquifer within the area.

Hydrologic effects of large, sustained withdrawals on both the aquifer and the land surface environment are projected, based on the different geohydrologic characteristics of the area. This type of general, qualitative approach is allowed by available data; more quantitative refinement will require additional data collection and interpretation.

\section{Areas of High Recharge}

Areas of high recharge are mostly karst terranes from which all drainage is internal and to the Upper Floridan aquifer. The land surface is generally very well drained and the water table is relatively deep. Surface waters are not abundant, and there are no permanent streams nor extensive wetland areas. Most surface waters occur in relatively small lakes that occupy closed karst (sinkhole) basins. Thus, on an areal basis, evapotranspiration is relatively low owing to the lack of surface or shallow ground waters. This factor, coupled with virtually no surface runoff results in the high natural recharge rates for these areas. Natural discharge, within the SWFWMD Basin, is mainly to springs and channels of streams which tend to occur at or near the outer boundaries of areas of high recharge.

The major source for capture of water to wells developed in these areas of high recharge is from a decrease in the natural discharge. The general lack of a thick saturated zone above the Upper Floridan aquifer would minimize the significance of induced downward leakage (an increase in recharge) in replenishment of water pumped from storage. The generally deep water table in these areas also would tend to preclude the capture of water from surface runoff and evapotranspiration. Thus, sustained withdrawals of large quantities of ground water in areas of high recharge would produce the following general results:

(a) The shape and rate of growth of the cone of depression in a well field would primarily be governed by the transmissivity and storage properties of the Upper Floridan aquifer, the rate of natural recharge, and the location of points or areas of discharge in relation to well fields. From a practical standpoint, the maximum capture of water possible is some amount less than the natural discharge (or natural recharge).

(b) The sustained development of ground water would have minimal effects on the wetness of the surface environment. That is, in these areas, there is little surface water or shallow ground water and rates of evapotranspiration are probably lower than in other areas of the basin. Therefore, the presence of a large cone of depression should not result in any large capture or downward diversion of water from the surface or near-surface environment. The single exception could be loss of water by downward leakage from lakes that have a direct hydraulic connection with the Upper Floridan. These lakes tend to have water levels that are close to the Upper Floridan aquifer potentiometric surface. However, those lakes that are perched in relation to the Upper Floridan potentiometric surface should not be affected by pumpage from the Upper Floridan aquifer. 


\section{Areas of Moderate Recharge}

Areas of moderate recharge generally are low-lying terranes from which moderate surface runoff occurs. The land surface is poorly to moderately well drained, and the potentiometric surface of the Upper Floridan aquifer and the water table generally are close to land surface. Surface waters occur as extensive wetlands, shallow lakes, or sluggish streams. Evapotranspiration losses generally are high. However, moderate amounts of recharge do occur to the Upper Floridan because overlying deposits are usually thin, or absent, and the water table generally is higher than the Upper Floridan aquifer potentiometric surface.

Sources for capture of water to wells developed in areas of moderate recharge are from (a) a decrease in the natural discharge, and (b) an increase in recharge. A major part of the total capture should be the increase in recharge. The increase in recharge would result from induced downward leakage of shallow ground water and surface water and decreased evapotranspiration for the area of the cone of depression. It is possible that this component of capture, for areas of moderate recharge, could exceed the total capture of water that can be achieved for areas of high recharge. Thus, for areas of moderate recharge, sustained withdrawals of large quantities of ground water would produce the following general results:

(a) The shape and rate of growth of the cone of depression in a well field would be influenced by the leakance coefficient of overburden materials and the availability and distribution of surface water, as well as by the location of natural discharge areas and the transmissivity and storage properties of the Upper Floridan aquifer. If capture by induced recharge in areas of moderate recharge is greater than the total capture in areas of high recharge, a smaller cone of depression would develop (for equivalent withdrawals) in an area of moderate recharge.

(b) The sustained development of ground water supplies would result in less water being available to the surface environment. This would occur because a significant amount of water withdrawn from wells would be induced into the cone of depression by downward leakage from surface, or near surface, sources. The ultimate effects on the land surface are speculative, based on available data; but it appears logical that sustained long-term withdrawals would permanently decrease wetness by significantly changing the water-budget elements in these wetland environments.

LOW-FLOW CONDITIONS IN THE BASIN, APRIL 13 THROUGH AUGUST 17, 1981, IN COMPARISON WITH CONDITIONS DURING OTHER PERIODS OF RECORD

Record, or near-record low-flow conditions occurred in the Withlacoochee River basin during 1981. Data to document these conditions were collected from April 13 through August 17, 1981.

Low flow is caused by rainfall deficiency, which when sufficiently severe, is termed "a drought." Drought means various things to various people. Drought can be considered a strictly meteorological phenomenon (Palmer, 1965). To a farmer, drought means too little soil moisture in the root zone 
of his crops. To an economist, drought means a water shortage that adversely affects any aspect of the economy. For the purposes of this report, drought means a deficiency of rainfall sufficient to cause prolonged deficient streamflow accompanied by cessation of flow or extraordinarily low flow. The following discussions are not concerned with the rainfall deficiency that resulted in low flow, but only with the low flow.

The purpose of this part of the report is to: (1) compare the low-flow conditions in the Withlacoochee River basin in 1981 with those in other notably dry years; (2) show the difference in the altitudes of the river, canal, or lake surface and the potentiometric surface of the Upper Floridan aquifer at selected sites (fig. 1; table 3) under various discharge conditions during the study period and compare these differences with those obtained from 1979 to 1984; (3) show the indicated exchange rates between the river and aquifer along selected reaches; (4) show aerial and terrestrial photographs documenting conditions during the study period; and (5) present data on the quality of surface water in the Withlacoochee River basin in April 1981 and compare these data with data obtained in May 1979.

\section{Comparison of Low-Flow Conditions in 1981 with Low-Flow Conditions During Other Notable Periods of Deficient Flow}

Analysis of low-flow conditions involves consideration of the relation between discharge and time. A flow-oriented analysis, in which the lowest average discharge during continuous time periods of selected duration during a year is computed for comparison, or frequency analysis, does not necessarily reflect low-flow conditions because the averages are computed for each year regardless of flow conditions during the year. A time-oriented analysis, in which the longest periods during which the discharge remains at or below a value considered to be low flow are compared, must necessarily reflect low-flow conditions, but are not restricted to any specific year. If only the lowest 25 percent of the computed averages for a flow-oriented analysis are considered, it is likely that only notable low-flow or near low-flow conditions will be reflected by the results of the analysis. To ensure that a time-oriented analysis reflects only notable low-flow periods, a period is considered notable only if the discharge recedes to or below a value considered extreme low flow.

The lowest mean discharges for $1,7,30,90$, and 183 consecutive days and for the water year (October 1 to September 30) were selected for comparison in the flow-oriented analysis of low-flow conditions. Data are shown in tables 4 and 5 only for years that fall within the lowest 25 percent of record. At Trilby (site 11) in the upper basin, low-flow conditions in 1981 are shown to be the most stringent since at least 1931. Near Holder (site 25) in the lower basin, conditions are shown to have been more stringent in 1956 than in 1981. However, the average discharge during the 365day period February 13, 1981, through February 12, 1982, was lower than in any other 365-day period of record.

For time-oriented analysis of low-flow conditions, the discharge equaled or exceeded 75 percent of the time was used to determine the beginning and end of a low-flow period. For evaluating whether or not a low-flow period was notable, the discharge, which was equaled or exceeded 96 percent of the time, was considered extreme low flow. At Trilby (site 11), flows of 63 and $20 \mathrm{ft}^{3} / \mathrm{s}$ (cubic feet per second) were considered notable and extreme low flows, values that have recurrence intervals of 1.11 and 3.3 years, 
Table 3. - Map numbers, file numbers, and station names for data-collection sites in the Withlacoochee River Basin of the Southwest Florida Water Management District

[See figure 1 for location]

\begin{tabular}{|c|c|c|}
\hline 0. & USGS file No. & tion name \\
\hline $\begin{array}{l}1 . \\
2 . \\
3 . \\
4 . \\
5 .\end{array}$ & $\begin{array}{l}02311500 \\
282111082073101 \\
02311700 \\
282528082090100 \\
282540082100900\end{array}$ & $\begin{array}{l}\text { Withlacoochee River near Dade City. } \\
\text { Cummer Trailer well near Dade City. } \\
\text { Dade City Canal near Dade City. } \\
\text { Withlacoochee River above Dobes Hole near Lacoochee. } \\
\text { Dade City Canal at Dobes Hole Prairie near Lacoochee. }\end{array}$ \\
\hline $\begin{array}{l}6 . \\
7 . \\
8 . \\
9 . \\
10 .\end{array}$ & $\begin{array}{l}282555082100900 \\
282606082095800 \\
02311787 \\
282653082074600 \\
2827500820808\end{array}$ & $\begin{array}{l}\text { Dobes Hole inflow near Lacoochee. } \\
\text { Dobes Hole outlet near Lacoochee. } \\
\text { Withlacoochee River near Lacoochee. } \\
\text { Devils Creek near Lacoochee. } \\
\text { Withlacoochee River at Lacoochee Park near Lacoochee. }\end{array}$ \\
\hline $\begin{array}{l}11 . \\
12 . \\
13 . \\
14 . \\
15\end{array}$ & $\begin{array}{l}02312000 \\
282847082103401 \\
283108082123401 \\
283109082123500 \\
283408082123801\end{array}$ & $\begin{array}{l}\text { Withlacoochee River at Trilby. } \\
\text { Tallisman Estates well at Trilby. } \\
\text { LeCompte well at Rital. } \\
\text { Withlacoochee River at Rital. } \\
\text { Cypress Glen Park well near Croom. }\end{array}$ \\
\hline $\begin{array}{l}16 . \\
17 . \\
18 . \\
19 . \\
20 .\end{array}$ & $\begin{array}{l}283454082131301 \\
02312500 \\
283840082154801 \\
283839082152700 \\
284317082142601\end{array}$ & $\begin{array}{l}\text { Withlacoochee State Forest well at Croom. } \\
\text { Withlacoochee River at Croom. } \\
\text { Barnhardt well at Nobleton. } \\
\text { Withlacoochee River at Nobleton. } \\
\text { Wynnhaven Camp well near Floral City. }\end{array}$ \\
\hline $\begin{array}{l}21 . \\
22 . \\
23 \\
24 . \\
25 \\
25 A\end{array}$ & $\begin{array}{l}02312600 \\
284443082121501 \\
02312645 \\
284215082092301 \\
02312698 \\
02312700\end{array}$ & $\begin{array}{l}\text { Withlacoochee River near Floral City. } \\
\text { Trails End we11 near Flora1 City. } \\
\text { Jumper Creek Canal near Wahoo. } \\
\text { JC-61 we11 near Wahoo. } \\
\text { Lake Panasoffkee near Lake Panasoffkee. } \\
\text { Outlet River at Panacoochee Retreats. }\end{array}$ \\
\hline $\begin{array}{l}26 . \\
27 . \\
28 \\
28 A \\
29 \\
30\end{array}$ & $\begin{array}{l}284809082080701 \\
284952082105501 \\
02312720 \\
02312719 \\
285106082131700 \\
285112082124001\end{array}$ & $\begin{array}{l}\text { Kent well near Lake Panasoffkee. } \\
\text { Gator Lodge wel1 at Carlson. } \\
\text { Withlacoochee River at Wysong Dam, at Carlson. } \\
\text { Withlacoochee River above Wysong Dam, at Carlson. } \\
\text { Withlacoochee River at Rutland. } \\
\text { Sumter } 12 \text { well at Rutland. }\end{array}$ \\
\hline $\begin{array}{l}31 . \\
32 \\
33 \\
34 \\
35\end{array}$ & $\begin{array}{l}285351082141100 \\
285441082165201 \\
285443082164900 \\
285500082165200 \\
02313000\end{array}$ & $\begin{array}{l}\text { Prairie Drain near Rutland. } \\
\text { J. Roy Dee well near Inverness. } \\
\text { Withlacoochee River at Turner R.M. } 1 \text { near Inverness. } \\
\text { Gum Slough near Rutland. } \\
\text { Withlacoochee River near Holder. }\end{array}$ \\
\hline $\begin{array}{l}36 . \\
37 . \\
38 . \\
39 . \\
40 . \\
41 .\end{array}$ & $\begin{array}{l}285920082205801 \\
290247082264301 \\
02313180 \\
02313200 \\
02313230 \\
02313250\end{array}$ & $\begin{array}{l}\text { Stokes Ferry well near Holder. } \\
\text { Dunnellon Sewage Plant well near Dunnellon. } \\
\text { Blue Run at Dunne1lon. } \\
\text { Withlacoochee River at Dunnellon. } \\
\text { Withlacoochee River at Inglis Dam near Dunnellon. } \\
\text { Withlacoochee River Bypass Channe1 near Inglis. }\end{array}$ \\
\hline
\end{tabular}


Table 4.--Discharge and rankings derived from flow-oriented analysis of low-flow conditions. Withlacoochee River at Trilby, Florida (1932-81)

[Values are lowest 25 percent of values for period. Discharge (Q) is mean for period in cubic feet per second]

\begin{tabular}{|c|c|c|c|c|c|c|c|c|c|c|c|c|}
\hline \multirow{3}{*}{$\begin{array}{l}\text { Water } \\
\text { year }\end{array}$} & \multicolumn{12}{|c|}{ Duration } \\
\hline & \multicolumn{2}{|c|}{1 day } & \multicolumn{2}{|c|}{7 days } & \multicolumn{2}{|c|}{30 days } & \multicolumn{2}{|c|}{90 days } & \multicolumn{2}{|c|}{183 days } & \multicolumn{2}{|c|}{1 year } \\
\hline & Q & Rank & $Q$ & Rank & $Q$ & Rank & 0 & Rank & 0 & Rank & $Q$ & Rank \\
\hline 1932 & 11 & 7 & 11 & 5 & 12 & 4 & 14 & 3 & 24 & 2 & 99 & 3 \\
\hline 1933 & 16 & 13 & 17 & 12 & 20 & 11 & - & - & - & - & - & - \\
\hline 1935 & - & - & - & - & 22 & 13 & 25 & 7 & 41 & 7 & - & - \\
\hline 1938 & - & - & - & - & - & - & 27 & 10 & - & - & - & - \\
\hline 1939 & 10 & 5 & 11 & 6 & 16 & 6 & 18 & 5 & 32 & 5 & - & - \\
\hline 1940 & 13 & 9 & 14 & 9 & - & - & - & - & - & - & - & - \\
\hline 1941 & - & - & - & - & - & - & 35 & 13 & - & - & - & - \\
\hline 1943 & 13 & 10 & 15 & 10 & 16 & 7 & 26 & 8 & 29 & 4 & 207 & 10 \\
\hline 1944 & 10 & 6 & 12 & 7 & 14 & 5 & 18 & 6 & 28 & 3 & 145 & 8 \\
\hline 1945 & 8.6 & 3 & 8.8 & 3 & 9.5 & 2 & 12 & 2 & 46 & 11 & - & - \\
\hline 1949 & 15 & 12 & 16 & 11 & 20 & 12 & 26 & 9 & 41 & 6 & - & - \\
\hline 1955 & & - & - & - & - & - & - & - & 53 & 13 & 216 & 13 \\
\hline 1956 & 10 & 4 & 10 & 4 & 17 & 8 & - & - & 43 & 8 & 99 & 4 \\
\hline 1962 & - & - & - & - & - & - & - & - & - & - & 114 & 5 \\
\hline 1968 & - & - & - & - & - & - & 32 & 11 & 45 & 9 & - & - \\
\hline 1971 & - & - & - & - & - & - & - & - & - & - & 175 & 9 \\
\hline 1972 & - & - & - & _ & - & - & - & - & - & - & 128 & 7 \\
\hline 1973 & - & - & 19 & 13 & 20 & 9 & - & - & - & - & 210 & 11 \\
\hline 1975 & 13 & 11 & - & - & - & - & 33 & 12 & 49 & 12 & 122 & 6 \\
\hline 1976 & 12 & 8 & 14 & 8 & 20 & 10 & - & - & - & - & 210 & 12 \\
\hline 1977 & 7.3 & 2 & 8.1 & 2 & 9.7 & 3 & 16 & 4 & 46 & 10 & 86 & 2 \\
\hline 1981 & 6.3 & 1 & 6.3 & 1 & 6.7 & 1 & 7.4 & 1 & 14 & 1 & 35 & 1 \\
\hline
\end{tabular}

respectively. Near Holder (site 35), the notable and extreme low-flow values were 500 and $230 \mathrm{ft}^{3} / \mathrm{s}$, values that have recurrence intervals of 1.21 and 3.3 years, respectively. The periods of record covered, and the ranked number of days and minimum discharge in the respective periods are given in tables 6 and 7 .

At Trilby (site 11), the low-flow condition criteria were met in 20 of the 51 years considered. Near Holder (site 35), the criteria were met in 17 of the 50 years of record considered. In 1938, 1939, 1940,1941, 1949, and 1972, the criteria were met at Trilby (site 11), but not near Holder (site 35). In 1962 and 1971, the criteria were met near Holder (site 35), but not at Trilby (site 11). At Trilby (site 11), the period of low flow in 1981 surpassed the next longest period by 135 days, and the minimum daily discharge during the period was the lowest of record. Near Holder (site 35), the period of low flow in 1981 surpassed the next longest period by only 34 days, and the minimum daily discharge was 11 percent higher than the minimum 
Table 5.- - Discharge and rankings derived from flow-oriented analysis of low-flow conditions, Withlacoochee River near Holder. Florida (1932-81)

[Values are lowest 25 percent of values for period. Discharge (Q) is mean for period in cubic feet per second]

\begin{tabular}{|c|c|c|c|c|c|c|c|c|c|c|c|c|}
\hline \multirow{3}{*}{$\begin{array}{l}\text { Water } \\
\text { year }\end{array}$} & \multicolumn{12}{|c|}{ Duration } \\
\hline & \multicolumn{2}{|c|}{1 day } & \multicolumn{2}{|c|}{7 days } & \multicolumn{2}{|c|}{30 days } & \multicolumn{2}{|c|}{90 days } & \multicolumn{2}{|c|}{183 days } & \multicolumn{2}{|c|}{1 year } \\
\hline & $Q$ & Rank & 0 & Rank & $Q$ & Rank & $Q$ & Rank & $Q$ & Rank & $Q$ & Rank \\
\hline 1932 & 166 & 9 & 171 & 9 & 185 & 5 & 264 & 11 & 288 & 4 & 395 & 3 \\
\hline 1933 & 147 & 5 & 164 & 7 & 196 & 8 & 234 & 8 & 266 & 3 & - & - \\
\hline 1935 & 184 & 13 & - & - & - & - & - & - & - & - & - & - \\
\hline 1943 & - & - & - & - & - & - & - & - & 361 & 11 & - & - \\
\hline 1944 & 166 & 10 & 176 & 10 & 194 & 6 & 231 & 7 & 297 & 5 & 364 & 9 \\
\hline 1945 & 148 & 6 & 153 & 5 & 160 & 3 & 214 & 3 & 407 & 13 & - & - \\
\hline 1955 & - & - & - & - & 233 & 13 & 260 & 10 & 334 & 9 & 464 & 5 \\
\hline 1956 & 113 & 1 & 119 & 1 & 130 & 1 & 142 & 1 & 191 & 1 & 334 & 1 \\
\hline 1957 & 146 & 4 & 167 & 8 & 213 & 10 & 230 & 6 & 337 & 10 & 612 & 8 \\
\hline 1962 & 150 & 7 & 151 & 3 & 165 & 4 & 220 & 4 & 330 & 8 & 452 & 4 \\
\hline 1963 & - & - & - & - & - & - & - & - & - & - & 645 & 10 \\
\hline 1968 & - & - & 193 & 11 & 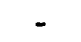 & - & - & - & 393 & 12 & - & - \\
\hline 1973 & - & - & - & - & - & - & - & - & - & - & 697 & 12 \\
\hline 1975 & 154 & 8 & 164 & 6 & 194 & 7 & 255 & 5 & 299 & 6 & 522 & 6 \\
\hline 1976 & 180 & 11 & 193 & 12 & 229 & 12 & 302 & 13 & - & - & 721 & 13 \\
\hline 1977 & 183 & 12 & 193 & 13 & 227 & 11 & 244 & 9 & 301 & 7 & 554 & 7 \\
\hline 1978 & - & - & - & - & - & - & - & - & - & - & 681 & 11 \\
\hline 1981 & 125 & 2 & 136 & 2 & 145 & 2 & 167 & 2 & 212 & 2 & 364 & 2 \\
\hline
\end{tabular}

Note: The lowest mean discharge for a 365-day period within the entire period of record ending September 30, 1982, was 263 cubic feet per second, February 13, 1981, through

February 12, 1982 .

of record. Thus, these data show that in the upper basin, low-flow conditions in 1981 were the most severe of record, but in the lower basin, less severe than in 1956 in some respects.

The fact that the 1981 period of low flow near Holder (site 35) began about 7 months later and ended about 6 months later than at Trilby (site 11) reflects the greater effects of the storage capacity of the Upper Floridan aquifer on the flow regime of the lower Withlacoochee River than of the upper Withlacoochee River. Discharge below which low flow is considered to exist is based on the entire period of record without regard to the seasonal norms. Thus, deficiency during the normally high-flow months is much greater than during the normally low-flow months.

Head Relations in the Basin, 1979-84, with Emphasis on 1981

"The Withlacoochee River rises in Polk County and for the most part, throughout its course to the Gulf of Mexico, at Inglis, it flows on limestone and through a limestone-walled channel." This statement by Vernon 
Table 6.--Periods of deficient flow, duration and ranking, and minimum discharge and ranking derived from timeoriented analysis of low-flow conditions, Withlacoochee River at Trilby, Florida

[Duration in days and discharge in cubic feet per second]

\begin{tabular}{|c|c|c|c|c|c|}
\hline \multicolumn{2}{|c|}{ Period } & \multirow[b]{2}{*}{ Duration } & \multicolumn{3}{|c|}{ Minimum } \\
\hline Began & Ended & & Rank & discharge & Rank \\
\hline $\begin{array}{l}12 / 27 / 31 \\
07 / 18 / 32 \\
10 / 13 / 32 \\
12 / 12 / 32 \\
05 / 15 / 33\end{array}$ & $\begin{array}{l}06 / 25 / 32 \\
08 / 17 / 32 \\
11 / 07 / 32 \\
02 / 13 / 33 \\
06 / 15 / 33\end{array}$ & $\begin{array}{r}182 \\
31 \\
26 \\
64 \\
32\end{array}$ & $\begin{array}{r}4 \\
23 \\
25 \\
18 \\
22\end{array}$ & $\begin{array}{l}11 \\
12 \\
16 \\
17 \\
16\end{array}$ & $\begin{array}{r}7 \\
8 \\
14 \\
17 \\
15\end{array}$ \\
\hline $\begin{array}{l}03 / 01 / 35 \\
03 / 08 / 38 \\
12 / 28 / 38 \\
05 / 08 / 40 \\
10 / 23 / 40\end{array}$ & $\begin{array}{l}07 / 17 / 35 \\
07 / 16 / 38 \\
06 / 18 / 39 \\
06 / 06 / 40 \\
01 / 16 / 41\end{array}$ & $\begin{array}{r}139 \\
131 \\
173 \\
30 \\
86\end{array}$ & $\begin{array}{r}7 \\
8 \\
5 \\
24 \\
13\end{array}$ & $\begin{array}{l}19 \\
20 \\
10 \\
13 \\
20\end{array}$ & $\begin{array}{r}19 \\
21 \\
4 \\
10 \\
22\end{array}$ \\
\hline $\begin{array}{l}10 / 28 / 42 \\
01 / 21 / 44 \\
02 / 23 / 45 \\
02 / 25 / 49 \\
03 / 08 / 55\end{array}$ & $\begin{array}{l}06 / 27 / 43 \\
07 / 30 / 44 \\
06 / 23 / 45 \\
07 / 29 / 49 \\
05 / 23 / 55\end{array}$ & $\begin{array}{r}243 \\
192 \\
121 \\
155 \\
77\end{array}$ & $\begin{array}{r}2 \\
3 \\
10 \\
6 \\
15\end{array}$ & $\begin{array}{l}13 \\
10 \\
8.6 \\
15 \\
20\end{array}$ & $\begin{array}{r}11 \\
5 \\
3 \\
13 \\
23\end{array}$ \\
\hline $\begin{array}{l}05 / 26 / 55 \\
03 / 12 / 56 \\
06 / 06 / 56 \\
02 / 25 / 68 \\
10 / 05 / 72\end{array}$ & $\begin{array}{l}07 / 17 / 55 \\
05 / 25 / 56 \\
08 / 21 / 56 \\
06 / 08 / 68 \\
12 / 20 / 72\end{array}$ & $\begin{array}{r}52 \\
75 \\
78 \\
105 \\
77\end{array}$ & $\begin{array}{l}21 \\
17 \\
14 \\
12 \\
16\end{array}$ & $\begin{array}{l}20 \\
16 \\
10 \\
20 \\
18\end{array}$ & $\begin{array}{r}24 \\
16 \\
6 \\
25 \\
18\end{array}$ \\
\hline $\begin{array}{l}03 / 24 / 75 \\
03 / 15 / 76 \\
04 / 02 / 77 \\
10 / 16 / 77 \\
08 / 18 / 80\end{array}$ & $\begin{array}{l}07 / 15 / 75 \\
05 / 15 / 76 \\
08 / 02 / 77 \\
12 / 12 / 77 \\
08 / 30 / 81\end{array}$ & $\begin{array}{r}114 \\
62 \\
123 \\
58 \\
378\end{array}$ & $\begin{array}{r}11 \\
19 \\
9 \\
20 \\
1\end{array}$ & $\begin{array}{c}13 \\
12 \\
7.3 \\
19 \\
6.3\end{array}$ & $\begin{array}{r}12 \\
9 \\
2 \\
20 \\
1\end{array}$ \\
\hline
\end{tabular}

(1951) suggests a potential relation between surface altitude of the Withlacoochee River and the potentiometric surface altitude of the Upper Floridan aquifer, which is in part comprised of the limestone over which the river flows. Altitude relations between the river surface and the potentiometric surface of the Upper Floridan aquifer are of interest because they potentially can affect the flow regime of the river. Where the surface of the river is higher than the aquifer potentiometric surface, a potential for the river to lose water to the aquifer exists. Where the river level is lower than the aquifer potentiometric surface, a potential for the river to gain water from the aquifer exists. Table 8 gives the head relation (difference in the altitudes of the river surface and aquifer potentiometric surface) between the river and the aquifer at selected locations under a variety of flow conditions from 1979 to 1984. The head relations between the potentiometric surface of the Upper Floridan aquifer and the water surfaces of 
Table 7.--Periods of deficient flow, duration and ranking, and minimum discharge and ranking derived from timeoriented analys is of low-flow conditions. Withlacoochee River near Holder. Florida

[Duration in days and discharge in cubic feet per second]

\begin{tabular}{lccccr}
\hline \multicolumn{2}{c}{ Period } & & & Minimum & \\
\hline Began & Ended & Duration & Rank & discharge & Rank \\
\hline $11 / 18 / 31$ & $09 / 04 / 32$ & 292 & 2 & 166 & 9 \\
$09 / 28 / 32$ & $07 / 12 / 33$ & 288 & 3 & 147 & 5 \\
$03 / 13 / 35$ & $07 / 15 / 35$ & 125 & 12 & 184 & 13 \\
$12 / 06 / 42$ & $07 / 03 / 43$ & 211 & 5 & 209 & 16 \\
$02 / 01 / 44$ & $08 / 06 / 44$ & 188 & 7 & 166 & 10 \\
$02 / 26 / 45$ & $06 / 24 / 45$ & 119 & 14 & 148 & 6 \\
$02 / 26 / 55$ & $08 / 14 / 55$ & 170 & 9 & 217 & 17 \\
$02 / 08 / 56$ & $10 / 16 / 56$ & 252 & 4 & 113 & 1 \\
$12 / 08 / 56$ & $04 / 19 / 57$ & 133 & 11 & 146 & 4 \\
$02 / 16 / 62$ & $07 / 21 / 62$ & 156 & 10 & 150 & 7 \\
& & & & & \\
$03 / 20 / 68$ & $06 / 17 / 68$ & 90 & 16 & 188 & 14 \\
$04 / 17 / 71$ & $06 / 26 / 71$ & 71 & 17 & 194 & 15 \\
$02 / 23 / 75$ & $08 / 31 / 75$ & 190 & 6 & 154 & 8 \\
$01 / 19 / 76$ & $05 / 21 / 76$ & 124 & 13 & 180 & 11 \\
$04 / 05 / 77$ & $09 / 22 / 77$ & 171 & 8 & 183 & 12 \\
& & & & & \\
$10 / 04 / 77$ & $01 / 08 / 78$ & 97 & 15 & 138 & 3 \\
$03 / 24 / 81$ & $02 / 12 / 82$ & 326 & 1 & 125 & 2 \\
\hline
\end{tabular}

Lake Panasoffkee near Lake Panasoffkee (site 25) and Jumper Creek Canal near Wahoo (site 23) also are given in table 8 . These data will be considered in the following discussion of gains and losses along selected reaches of the Withlacoochee River and its tributaries.

\section{Exchange of Water Between the Withlacoochee River and the Upper} Floridan Aquifer Along Selected Reaches of the River in 1981

As indicated by the data in table 8 , a potential for exchange of water between the Withlacoochee River and the Upper Floridan aquifer exists at all of the data-collection sites. The data in table 9 show that water does, in fact, seep into or out of the river. A comparison of the data in tables 8 and 9 indicates, however, that the potential for seepage at some of the sites does not agree with direction of the net seepage from the intervening reach. This indicates that the head differences at the data sites are merely not representative of the overall head differences throughout the reach in question. 
Table 8.--River water-surface (WS) altitudes, Upper Floridan aquifer potentiometric surface (PS) altitudes, head difference (HD), and discharge (Q) at selected sites in the Withlacoochee River basin $(1979-84)$

[Altitude and head difference in feet, and discharge in cubic feet per second]

\begin{tabular}{|c|c|c|c|c|c|c|}
\hline \multirow{2}{*}{$\begin{array}{l}\text { Map } \\
\text { No. }\end{array}$} & \multirow[b]{2}{*}{ Site name and file No. } & \multirow[b]{2}{*}{ Date } & \multicolumn{2}{|c|}{ Altitude } & \multirow[b]{2}{*}{ HD } & \multirow[b]{2}{*}{ Q } \\
\hline & & & WS & PS & & \\
\hline 1 & $\begin{array}{l}\text { Withlacoochee River near Dade City, } 02311500 \\
\text { Cummer Trailer well, } 282111082073101\end{array}$ & $\begin{array}{l}05 / 17 / 79 \\
07 / 03 / 79 \\
09 / 20 / 79 \\
04 / 13 / 81 \\
05 / 06 / 81 \\
05 / 18 / 81 \\
05 / 28 / 81 \\
06 / 19 / 81 \\
07 / 02 / 81 \\
07 / 07 / 81 \\
08 / 14 / 81 \\
05 / 10 / 82 \\
09 / 13 / 82 \\
05 / 24 / 83 \\
09 / 16 / 83\end{array}$ & $\begin{array}{l}72.73 \\
70.03 \\
75.04 \\
68.79 \\
68.14 \\
67.44 \\
66.60 \\
67.38 \\
68.63 \\
68.22 \\
68.61 \\
69.17 \\
73.86 \\
69.62 \\
73.28\end{array}$ & $\begin{array}{c}72.18 \\
70.38 \\
74.63 \\
68.16 \\
67.46 \\
67.05 \\
66.64 \\
66.43 \\
- \\
66.64 \\
67.33 \\
69.98 \\
73.32 \\
72.54 \\
74.24\end{array}$ & $\begin{array}{r}0.55 \\
-\quad .35 \\
.41 \\
.63 \\
.68 \\
.39 \\
-.04 \\
.95 \\
.9 \\
1.58 \\
1.28 \\
-\quad .81 \\
-2.54 \\
-2.92 \\
-\quad .96\end{array}$ & $\begin{array}{r}406 \\
39 \\
1,200 \\
7.0 \\
14.0 \\
12.4 \\
121.0 \\
11.2 \\
110 \\
1.9 \\
3.5 \\
- \\
- \\
- \\
-\end{array}$ \\
\hline 11 & $\begin{array}{l}\text { Withlacoochee River at Trilby, } 02312000 \\
\text { Tallisman Estates well at Trilby, } 282847082103401\end{array}$ & $\begin{array}{l}05 / 17 / 79 \\
09 / 21 / 79 \\
05 / 16 / 80 \\
09 / 16 / 80 \\
04 / 13 / 81 \\
05 / 06 / 81 \\
05 / 18 / 81 \\
06 / 19 / 81 \\
07 / 07 / 81 \\
08 / 14 / 81 \\
05 / 10 / 82 \\
09 / 13 / 82 \\
05 / 24 / 83 \\
09 / 16 / 83 \\
05 / 15 / 84 \\
05 / 14 / 84\end{array}$ & $\begin{array}{l}54.17 \\
61.65 \\
51.01 \\
50.86 \\
50.77 \\
50.11 \\
49.97 \\
50.09 \\
50.38 \\
50.87 \\
50.55 \\
58.09 \\
51.15 \\
57.83 \\
51.27 \\
51.35\end{array}$ & $\begin{array}{c}55.45 \\
21 \\
53.33 \\
52.70 \\
51.70 \\
51.12 \\
50.87 \\
50.67 \\
51.00 \\
52.56 \\
53.51 \\
59.32 \\
55.14 \\
59.05 \\
54.45 \\
54.94\end{array}$ & $\begin{array}{l}-1.28 \\
- \\
-2.32 \\
-1.84 \\
-.93 \\
-1.01 \\
-\quad .90 \\
-\quad .58 \\
-.62 \\
-1.69 \\
-2.96 \\
-1.23 \\
-3.99 \\
-1.22 \\
-3.18 \\
-3.59\end{array}$ & $\begin{array}{r}284 \\
1,900 \\
65 \\
38 \\
14 \\
8.6 \\
8.2 \\
6.3 \\
6.8 \\
10.7 \\
36 \\
793 \\
67 \\
821 \\
- \\
-\end{array}$ \\
\hline 14 & Withlacoochee River at Rital, 283109082123500 & $\begin{array}{l}05 / 17 / 79 \\
09 / 21 / 79\end{array}$ & $\begin{array}{l}47.48 \\
55.63\end{array}$ & $\begin{array}{l}49.33 \\
54.01\end{array}$ & $\begin{array}{r}-1.85 \\
1.62\end{array}$ & - \\
\hline 13 & LeCompte well at Rital, 283108082123401 & $\begin{array}{l}05 / 16 / 80 \\
04 / 14 / 81 \\
05 / 08 / 81 \\
05 / 14 / 81 \\
05 / 19 / 81 \\
06 / 04 / 81 \\
06 / 19 / 81 \\
07 / 07 / 81 \\
07 / 23 / 81 \\
05 / 11 / 82 \\
09 / 14 / 82\end{array}$ & $\begin{array}{l}46.20 \\
44.07 \\
43.73 \\
43.64 \\
43.63 \\
43.64 \\
43.50 \\
43.63 \\
43.81 \\
45.03 \\
51.85\end{array}$ & $\begin{array}{l}47.47 \\
45.06 \\
44.62 \\
44.50 \\
44.42 \\
44.20 \\
43.97 \\
43.87 \\
44.28 \\
48.24 \\
52.92\end{array}$ & $\begin{array}{l}-1.27 \\
-\quad .99 \\
-\quad .89 \\
-\quad .86 \\
-.79 \\
-\quad .56 \\
-\quad .47 \\
-\quad .24 \\
-.47 \\
-3.21 \\
-1.07\end{array}$ & $\begin{array}{c}17.5 \\
1_{8}^{-} \\
6.5 \\
- \\
1_{3}^{-} \\
2.9 \\
- \\
- \\
-\end{array}$ \\
\hline 17 & Withlacoochee River at Croom, 02312500 & $\begin{array}{l}05 / 17 / 79 \\
09 / 20 / 79\end{array}$ & $\begin{array}{l}43.84 \\
47.49\end{array}$ & $\begin{array}{l}43.27 \\
46.50\end{array}$ & .57 & $\begin{array}{r}361 \\
900\end{array}$ \\
\hline 16 & $\begin{array}{l}\text { Withlacoochee State Forest well at Croom, } \\
283454082131301\end{array}$ & $\begin{array}{l}05 / 16 / 80 \\
09 / 16 / 80 \\
04 / 14 / 81 \\
05 / 06 / 81 \\
05 / 19 / 81 \\
07 / 07 / 81 \\
09 / 22 / 81 \\
05 / 11 / 82 \\
09 / 14 / 82 \\
05 / 17 / 83 \\
09 / 15 / 83 \\
05 / 15 / 84 \\
09 / 14 / 84\end{array}$ & $\begin{array}{l}41.37 \\
41.51 \\
40.64 \\
40.46 \\
40.37 \\
40.01 \\
43.63 \\
42.02 \\
46.86 \\
43.33 \\
46.22 \\
42.90 \\
44.11\end{array}$ & $\begin{array}{l}41.79 \\
41.50 \\
39.97 \\
39.56 \\
39.29 \\
38.53 \\
40.82 \\
44.60 \\
48.05 \\
46.44 \\
46.83 \\
44.53 \\
45.62\end{array}$ & $\begin{array}{r}-.42 \\
.01 \\
.67 \\
.90 \\
1.08 \\
1.48 \\
2.81 \\
-2.58 \\
-1.19 \\
-3.11 \\
-.61 \\
-1.63 \\
-1.51\end{array}$ & $\begin{array}{c}90 \\
56 \\
21 \\
13 \\
8.2 \\
4.5 \\
136 \\
130 \\
1,410 \\
323 \\
1,040 \\
299 \\
492\end{array}$ \\
\hline
\end{tabular}

1 Estimated.

${ }^{2}$ Well submerged. 
Table 8.--River water-surface (WS) altitudes, Upper Floridan aguifer potentiometric surface (PS) altitudes, head difference (HD), and discharge (Q) at selected sites in the Withlacoochee River basin $(1979-84)^{--C o n t i n u e d}$

[Altitude and head difference in feet, and discharge in cubic feet per second]

\begin{tabular}{|c|c|c|c|c|c|c|}
\hline \multirow{2}{*}{$\begin{array}{l}\text { Map } \\
\text { No. }\end{array}$} & \multirow[b]{2}{*}{ Site name and file No. } & \multirow[b]{2}{*}{ Date } & \multicolumn{2}{|c|}{ Altitude } & \multirow[b]{2}{*}{$\mathrm{HD}$} & \multirow[b]{2}{*}{$Q$} \\
\hline & & & WS & PS & & \\
\hline 19 & $\begin{array}{l}\text { Withlacoochee River at Nobleton; } 283839082152700 \\
\text { Barnhardt well at Nobleton, } 283840082154801\end{array}$ & $\begin{array}{l}05 / 17 / 79 \\
04 / 01 / 81 \\
04 / 14 / 81 \\
05 / 06 / 81 \\
05 / 14 / 81 \\
05 / 19 / 81 \\
05 / 28 / 81 \\
06 / 04 / 81 \\
06 / 19 / 81 \\
07 / 02 / 81 \\
07 / 07 / 81 \\
07 / 09 / 81 \\
07 / 23 / 81 \\
08 / 14 / 81 \\
08 / 17 / 81 \\
05 / 11 / 82 \\
09 / 14 / 82\end{array}$ & $\begin{array}{l}41.93 \\
39.64 \\
39.20 \\
38.69 \\
38.55 \\
38.45 \\
38.56 \\
38.55 \\
37.94 \\
37.93 \\
37.76 \\
38.05 \\
38.14 \\
38.46 \\
38.37 \\
40.29 \\
43.73\end{array}$ & $\begin{array}{l}40.92 \\
38.22 \\
37.99 \\
37.48 \\
37.30 \\
37.14 \\
36.68 \\
36.32 \\
36.59 \\
36.41 \\
36.29 \\
36.36 \\
36.27 \\
36.45 \\
36.44 \\
41.26 \\
45.92\end{array}$ & $\begin{array}{l}1.01 \\
1.42 \\
1.21 \\
1.21 \\
1.25 \\
1.31 \\
1.88 \\
2.23 \\
1.35 \\
1.52 \\
1.47 \\
1.69 \\
1.87 \\
2.01 \\
1.93 \\
-.97 \\
-2.19\end{array}$ & $\begin{array}{c}28 \\
17.3 \\
8 \\
5.4 \\
7 . \\
- \\
1.3 \\
- \\
.1 \\
- \\
11.2 \\
8.9 \\
- \\
-\end{array}$ \\
\hline 21 & Withlacoochee River near Floral City, 02312600 & $\begin{array}{l}05 / 16 / 79 \\
04 / 14 / 81\end{array}$ & $\begin{array}{l}41.51 \\
39.00\end{array}$ & $\begin{array}{l}42.64 \\
39.85\end{array}$ & $\begin{array}{l}-1.13 \\
-\quad .85\end{array}$ & 36.7 \\
\hline 22 & Trails End well near Floral City, 284443082121501 & $\begin{array}{l}05 / 06 / 81 \\
05 / 20 / 81 \\
07 / 07 / 81 \\
07 / 21 / 81 \\
07 / 23 / 81 \\
07 / 24 / 81 \\
05 / 12 / 82 \\
09 / 15 / 82 \\
05 / 19 / 83 \\
09 / 15 / 83 \\
05 / 16 / 84 \\
09 / 12 / 84\end{array}$ & $\begin{array}{l}38.41 \\
37.96 \\
37.45 \\
37.64 \\
37.63 \\
37.68 \\
39.76 \\
42.39 \\
41.00 \\
42.12 \\
40.58 \\
41.20\end{array}$ & $\begin{array}{c}138.81 \\
38.3 \\
37.47 \\
- \\
37.55 \\
37.66 \\
40.54 \\
43.45 \\
41.90 \\
42.49 \\
41.63 \\
41.96\end{array}$ & $\begin{array}{r}-\quad .40 \\
-\quad .34 \\
-.02 \\
- \\
.08 \\
.02 \\
-.78 \\
-1.06 \\
-\quad .90 \\
-.37 \\
-1.05 \\
-\quad .76\end{array}$ & $\begin{array}{c}18^{-} \\
- \\
0.0 \\
-5.0 \\
- \\
- \\
- \\
- \\
- \\
-\end{array}$ \\
\hline
\end{tabular}

23 Jumper Creek Canal near Wahoo, 02312645

24 JC-61 well near Wahoo, 284215082092301
$04 / 30 / 79$

$09 / 18 / 79$

$05 / 12 / 80$

$09 / 17 / 80$

$04 / 15 / 81$

$05 / 20 / 81$

$09 / 23 / 81$

$05 / 12 / 82$

$09 / 15 / 82$

$05 / 16 / 84$

$09 / 12 / 84$

$05 / 01 / 79$

$05 / 13 / 80$

$04 / 15 / 81$

$05 / 06 / 81$

$05 / 13 / 81$

$05 / 20 / 81$

$09 / 23 / 81$

$05 / 13 / 82$

$09 / 16 / 82$

$05 / 26 / 83$

$09 / 12 / 83$

$05 / 17 / 84$

$346.84 \quad 45.95$

$346.66 \quad 46.49$

$346.80 \quad 45.81$

$\begin{array}{ll}346.80 & 45.81 \\ 346.29 & 45.76\end{array}$

$34.55 \quad 45.23$

$346.53 \quad 44.21$

$346.02 \quad 44.54$

$\begin{array}{ll}346.02 & 44.54 \\ 46.81 & 46.33\end{array}$

$\begin{array}{ll}346.81 & 46.33 \\ 47.08 & 47.05\end{array}$

$347.00 \quad 46.48$

$\begin{array}{ll}34.97 & 46.52\end{array}$

.89

.17
.99

.99
.53

1. 32

2. 32

1. 48

.48
.03

.03

. .52

41
29

34

1.5

18

4.8

35

41

57

$\begin{array}{lll}{ }_{4}^{4} 39.61 & 39.91 & -.30 \\ 439.20 & 39.58 & -.38\end{array}$

$439.20 \quad 39.58$

$\begin{array}{ll}{ }_{4} 39.20 & 39.58 \\ 438.48 & 38.46\end{array}$

${ }_{4}^{4} 38.17 \quad 38.17$

$438.04 \quad 38.58$

$437.90 \quad 38.31$

$438.19 \quad 38.34$
48

$\begin{array}{ll}439.18 & 39.57\end{array}$

$440.10 \quad 40.54$

$439.62 \quad 40.00$

$\begin{array}{ll}439.62 & 40.00 \\ 40.04 & 40.36\end{array}$

$\begin{array}{ll}440.04 & 40.36 \\ 39.51 & 39.90\end{array}$

$\begin{array}{ll}439.51 & 39.90 \\ 39.54 & 39.99\end{array}$

.02

.00

$-.54$

-.41
-.15

-.15
$-\quad .39$

$-.44$

$-.38$

.38
$-\quad .32$

-.32
$-\quad .39$

-.39
$-\quad .45$

1 Estimated.

3 Altitude of canal surface.

4 Altitude of lake surface.

5 Discharge of Outlet River at Panacoochee Retreats, 02312700. 
Table 8.--River water-surface (WS) altitudes, Upper Floridan aquifer potentiometric surface (PS) altitudes, head difference (HD), and discharge (Q) at selected sites in the Withlacoochee River basin $(1979-84)-$ Continued

[Altitude and head difference in feet, and discharge in cubic feet per second]

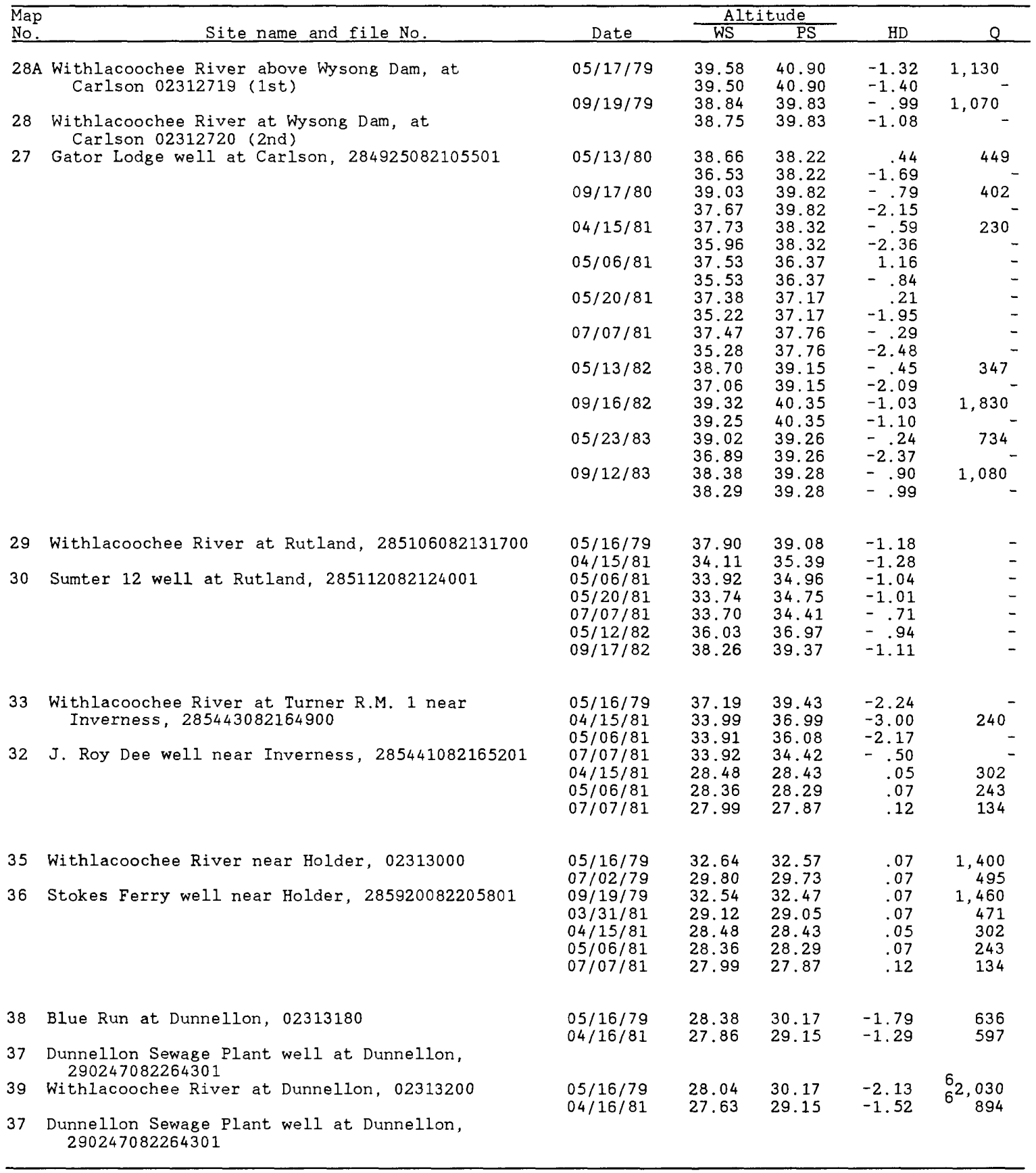

${ }^{6}$ Sum of 02313000 and 02313100 . 
Table 9.--Calculated seepage rates along selected reaches of the Withlacoochee River when change in channel storage is disregarded

[Discharge (Q) and net seepage in cubic feet per second]

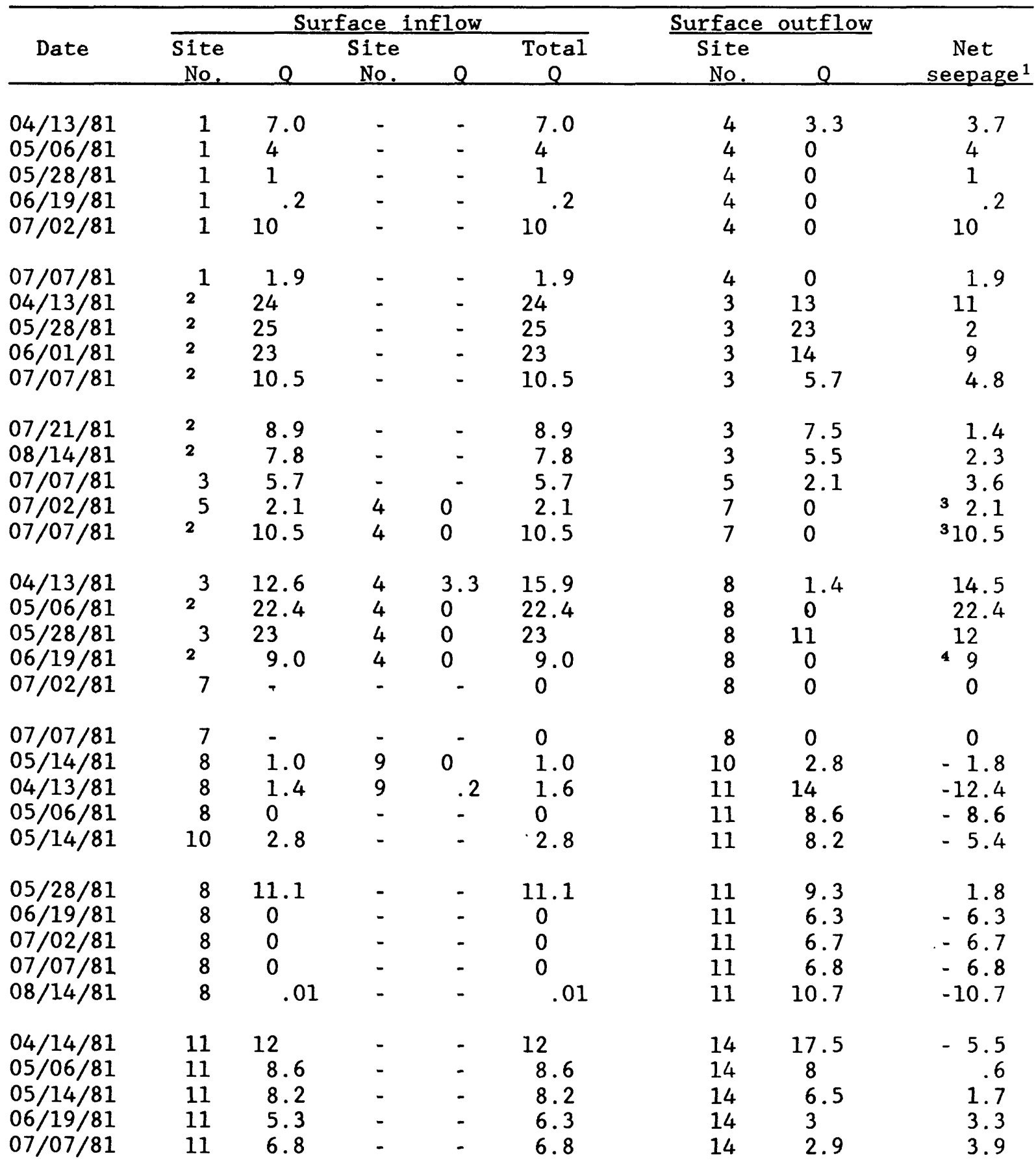


Table 9.--Calculated seepage rates along selected reaches of the Withlacoochee River when change in channel storage is disregarded--Continued

[Discharge (Q) and net seepage in cubic feet per second]

\begin{tabular}{|c|c|c|c|c|c|c|c|c|}
\hline \multirow[b]{2}{*}{ Date } & \multicolumn{5}{|c|}{ Surface inflow } & \multicolumn{2}{|c|}{ Surface outflow } & \multirow[b]{2}{*}{$\begin{array}{c}\text { Net } \\
\text { seepage } 1\end{array}$} \\
\hline & $\begin{array}{l}\text { Site } \\
\text { No. }\end{array}$ & $\mathrm{Q}$ & $\begin{array}{l}\text { Site } \\
\text { No. }\end{array}$ & Q & $\begin{array}{c}\text { Total } \\
Q\end{array}$ & $\begin{array}{l}\text { Site } \\
\text { No. }\end{array}$ & $\mathrm{Q}$ & \\
\hline $04 / 14 / 81$ & 14 & 17.5 & 5 & 1.0 & 18.5 & 17 & 21 & -2.5 \\
\hline $05 / 06 / 81$ & 14 & 8 & 5 & .1 & 8.1 & 17 & 13 & -4.9 \\
\hline $05 / 14 / 81$ & 14 & 6.5 & 5 & 0 & 6.5 & 17 & 11 & -4.5 \\
\hline $06 / 19 / 81$ & 14 & 3 & 5 & 0 & 3 & 17 & 4.8 & -1.8 \\
\hline $07 / 07 / 81$ & 14 & 2.9 & 5 & 0 & 2.9 & 17 & 4.5 & -1.6 \\
\hline $04 / 14 / 81$ & 17 & 21 & - & - & 21 & 19 & 17.3 & 3.7 \\
\hline $05 / 06 / 81$ & 17 & 13 & - & - & 13 & 19 & 8 & 5 \\
\hline $05 / 14 / 81$ & 17 & 11 & - & - & 11 & 19 & 5.4 & 5.6 \\
\hline $05 / 28 / 81$ & 17 & 9.8 & - & - & 9.8 & 19 & 7.1 & 2.7 \\
\hline $06 / 19 / 81$ & 17 & 4.8 & - & - & 4.8 & 19 & 1.3 & 3.5 \\
\hline $07 / 07 / 81$ & 17 & 4.5 & - & - & 4.5 & 19 & .1 & 4.4 \\
\hline $08 / 14 / 81$ & 17 & 15 & - & - & 15 & 19 & 11.2 & 3.8 \\
\hline $08 / 14 / 81$ & 17 & 15 & - & - & 15 & 19 & 11.2 & 3.8 \\
\hline $08 / 17 / 81$ & 17 & 14 & - & - & 14 & 19 & 8.9 & 5.1 \\
\hline $04 / 14 / 81$ & 19 & 17.3 & - & - & 17.3 & 21 & 36.7 & -19.4 \\
\hline $05 / 20 / 81$ & 17 & 8.6 & - & - & 8.6 & 21 & 18 & -9.4 \\
\hline $07 / 20 / 81$ & 17 & 9.3 & - & - & 9.3 & 21 & negative & $>9.3$ \\
\hline $07 / 21 / 81$ & 17 & 8.3 & 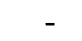 & - & 8.3 & 21 & 0 & 8.3 \\
\hline $07 / 23 / 81$ & 17 & 8.9 & . & - & - & 21 & $>0$ & $<8.9$ \\
\hline $07 / 24 / 81$ & 17 & 15 & - & - & - & 21 & -5.0 & 20 \\
\hline
\end{tabular}

\footnotetext{
1 Positive values indicate seepage out of channel. Negative values indicate seepage into channel.

${ }^{2}$ Citrus processing plant discharge into Dade City Canal 7,000 feet upstream from site 3 measuring section.

${ }^{3}$ Inflow to Dobes Hole at site 6 observed.

43.3 cubic feet per second into Dobes Hole at site 6.

${ }^{5}$ Little Withlacoochee River at Rerde11, 02312200.
} 
Under conditions of high aquifer potentiometric surface altitudes, the river probably gains water from the aquifer throughout most of its course from Dade City to Dunnellon. Under the conditions that existed in 1981, the net difference of gains and losses from the river in the upper half of its basin nearly equaled zero on July 7, with the part of the river in the gaining mode decreasing in length as the severity of the low-flow conditions increased. Although the river may have lost some water to the aquifer along some reaches of the channel downstream from Nobleton, these losses were apparently minor in comparison with gains from the aquifer in the lower half of the basin.

\section{Quality of Surface Water in the Basin in April 1981. and Comparison with Quality in May 1979}

During Phase I of the program for geohydrologic studies in the basin, a low-flow and water-quality reconnaissance was planned for mid-May 1979 with the expectation that base-flow conditions would exist at that time. However, unusually heavy rainfall occurred (about 3.5 times normal) in the first half of May so that some direct runoff was probably occurring when the reconnaissance was carried out May 16, 17, and 22, 1979. Discharges at Trilby, Croom, and near Holder were of a magnitude exceeded only 25 to 35 percent of the time.

On April 8, 1981, discharge of the Withlacoochee River had fallen to that exceeded nearly 99 percent of the time at Trilby and Croom and to that exceeded about 89 percent of the time hear Holder. A low-flow reconnaissance was made April 13 through 16 along with field measurements of waterquality parameters and sample collection.

Table 10 presents surface-water quality data that were obtained in May 1979 and in April 1981. At some sites, the 1979 data are incomplete or no data were obtained. A11 data collected in 1981 are included even if no 1979 data are available for comparison.

Complete data are available at sites 1, 35, and 41 on the Withlacoochee River and for its major tributaries, Outlet River and Rainbow Springs. The 1981 data for Rainbow Springs were obtained May 29 and that for Blue Run, April 14. The published discharge for May 29 was 96 percent of that for April 14 and the water level in Rainbow Springs wel1 near Dunne11on (290514082270701) (not listed in table 3 nor shown in figure 7) was only about 3 inches lower on May 29 than on April 14. Therefore, it is assumed that the quality of the water from Rainbow Springs was about the same on the two dates. Because the values for Rainbow Springs and Blue Run are very similar, the data for the springs are considered to be representative of the run.

In general, specific conductance, hardness, base metals, alkalinity, bicarbonates, and dissolved solids are lower at high discharge than at low discharge. Color and noncarbonate hardness are higher at high discharge than at low discharge. There appears to be no particular relation between discharge and the remaining parameters.

The differences in the values are much greater in the upper basin than in the lower basin and the tributaries; probably because the ratio of direct runoff to ground-water inseepage at high flow is greater in the upper basin. 


\section{Photographic Documentation of Low-Flow Conditions}

\section{in the Basin in June and July 1981}

On April 8, 1981, discharge at Trilby (site 11) had declined to a value exceeded 99 percent of the time. Therefore, the initial field investigation for this study was carried out in the following week, April 13 through 16, with the expectation that low-flow conditions were unlikely to become much more severe, particularly in the upper basin. However, the drought continued, and on June 19, Norvel W. Hunt, Director of Environmental Control, Lykes-Pasco Packing Company, reported that Dobes Hole sink was taking water. At this point, it was concluded that this phenomenon and the other conditions already observed in the basin indicated an outstanding low-flow condition that should be documented photographically as well as statistically. Because the effects of the drought were so much more evident in the upper half of the basin than in the lower half, most of this effort was concentrated in the upper basin. The photographs (figs. 9-31) are presented on a site by site basis in downstream order. 
Table 10. - Water-quality data for selected sites in the

\begin{tabular}{|c|c|c|c|c|c|c|c|c|c|c|}
\hline $\begin{array}{l}\text { Map } \\
\text { No. }\end{array}$ & Name of site & Year & $\begin{array}{l}\text { Dis- } \\
\text { charge }\end{array}$ & $\begin{array}{l}\text { Spe- } \\
\text { cific } \\
\text { con- } \\
\text { duct } \overline{2} \\
\text { ance }\end{array}$ & $\mathrm{pH}$ & $\begin{array}{l}\text { Tem- } \\
\text { pera } \\
\text { ture }\end{array}$ & Color ${ }^{4}$ & $\begin{array}{l}\operatorname{Hard}_{\overline{5}} \\
\text { ness }\end{array}$ & $\begin{array}{l}\text { Non- } \\
\text { car- } \\
\text { bon- } \\
\text { ate } \\
\text { hard- } \\
\text { ness }\end{array}$ & $\begin{array}{l}\text { Dis- } \\
\text { solved } \\
\text { cal- } \\
\text { cium }\end{array}$ \\
\hline $\begin{array}{r}1 \\
3 \\
4 \\
8 \\
11\end{array}$ & $\begin{array}{l}\text { Withlacoochee River near Dade City } \\
\text { Dade City Canal near Dade City } \\
\text { Withlacoochee River above Dobes } \\
\text { Hole near Lacoochee } \\
\text { Withlacoochee River near Lacoochee } \\
\text { Withlacoochee River at Trilby }\end{array}$ & $\begin{array}{c}1979 \\
1981 \\
1979 \\
1981 \\
1979 \\
1981 \\
1979 \\
1981 \\
1979 \\
1981\end{array}$ & $\begin{array}{c}289 \\
7.0 \\
30 \\
13 \\
- \\
3.3 \\
- \\
1.4 \\
360 \\
13\end{array}$ & $\begin{array}{c}118 \\
372 \\
320 \\
370 \\
- \\
325 \\
- \\
310 \\
145 \\
385\end{array}$ & $\begin{array}{l}6.7 \\
6.6 \\
6.7 \\
7.2 \\
-. \\
7.6 \\
-. \\
8.3 \\
6.9 \\
6.8\end{array}$ & $\begin{array}{c}22.5 \\
23.5 \\
26.0 \\
27.5 \\
- \\
25.0 \\
- \\
31.0 \\
25.0 \\
25.0\end{array}$ & $\begin{array}{c}400 \\
70 \\
- \\
10 \\
- \\
55 \\
\overline{40} \\
\overline{10}\end{array}$ & $\begin{array}{c}53 \\
160 \\
- \\
140 \\
- \\
140 \\
\overline{140} \\
\overline{180}\end{array}$ & $\begin{array}{r}20 \\
11 \\
\overline{0} \\
- \\
31 \\
-5 \\
5 \\
4\end{array}$ & $\begin{array}{r}18 \\
57 \\
- \\
45 \\
- \\
51 \\
\overline{7} \\
47 \\
- \\
66\end{array}$ \\
\hline $\begin{array}{l}14 \\
17 \\
19 \\
21 \\
23\end{array}$ & $\begin{array}{l}\text { Withlacoochee River at Rital } \\
\text { Withlacoochee River at Croom } \\
\text { Withlacoochee River at Nobelton } \\
\text { Withlacoochee River near Floral } \\
\text { City Creek Canal near Wahoo } \\
\text { Jumper Cres }\end{array}$ & $\begin{array}{c}1979 \\
1981 \\
1979 \\
1981 \\
1979 \\
1981 \\
1979 \\
1981 \\
1979 \\
1981\end{array}$ & $\begin{array}{r}1 \overline{18} \\
400 \\
20 \\
- \\
17 \\
447 \\
37 \\
- \\
21\end{array}$ & $\begin{array}{c}- \\
340 \\
165 \\
295 \\
- \\
285 \\
190 \\
265 \\
- \\
405\end{array}$ & $\begin{array}{l}- \\
7.9 \\
6.9 \\
6.4 \\
7.9 \\
7.9 \\
7.1 \\
-9 \\
6.4\end{array}$ & $\begin{array}{c}- \\
24.5 \\
24.5 \\
26.0 \\
- \\
26.5 \\
24.5 \\
27.5 \\
- \\
25.5\end{array}$ & $\begin{array}{l}- \\
10 \\
\overline{15} \\
\overline{10} \\
\overline{10} \\
\overline{10} \\
- \\
5\end{array}$ & $\begin{array}{c}\overline{160} \\
\overline{-} \\
140 \\
\overline{120} \\
\overline{110} \\
\overline{200}\end{array}$ & $\begin{array}{c}\overline{7} \\
\overline{9} \\
\overline{6} \\
- \\
3 \\
- \\
12\end{array}$ & $\begin{array}{r}5 \overline{5} \\
\overline{4} \\
\overline{8} \\
4 \overline{3} \\
\overline{38} \\
\overline{-} \\
7 \overline{5}\end{array}$ \\
\hline $\begin{array}{l}25 A \\
28 \\
31 \\
33 \\
34\end{array}$ & $\begin{array}{l}\text { Outlet River at Panacoochee } \\
\text { Retreats } \\
\text { Withlacoochee River at Wysong } \\
\text { Dam at Carlson } \\
\text { Prairie Drain near Rutland } \\
\text { Withlacoochee River at Turner } \\
\text { R.M. } 1 \text { near Inverness } \\
\text { Gum Slough near Rutland }\end{array}$ & $\begin{array}{c}1979 \\
1981 \\
1979 \\
1981 \\
1979 \\
1981 \\
1979 \\
1981 \\
1979 \\
1981\end{array}$ & $\begin{array}{r}413 \\
89 \\
1,000 \\
239 \\
- \\
15 \\
- \\
24 \overline{2} \\
94\end{array}$ & $\begin{array}{l}210 \\
250 \\
260 \\
280 \\
- \\
300 \\
- \\
330 \\
- \\
310\end{array}$ & $\begin{array}{l}7.7 \\
7.2 \\
7.1 \\
7.7 \\
.- \\
7.8 \\
.- \\
6.9 \\
-.3 \\
7.3\end{array}$ & $\begin{array}{c}26.0 \\
25.5 \\
24.5 \\
27.0 \\
- \\
23.0 \\
- \\
28.5 \\
- \\
24.0\end{array}$ & $\begin{array}{l}35 \\
20 \\
- \\
20 \\
-5 \\
-5 \\
10 \\
- \\
5\end{array}$ & $\begin{array}{c}97 \\
110 \\
\overline{110} \\
\overline{1} \\
150 \\
\overline{140} \\
\overline{150} \\
150\end{array}$ & $\begin{array}{r}38 \\
35 \\
\overline{-} \\
33 \\
\overline{1} \\
19 \\
\overline{-} \\
39 \\
\overline{6} \\
26\end{array}$ & $\begin{array}{r}32 \\
36 \\
- \\
37 \\
- \\
50 \\
- \\
57 \\
- \\
49\end{array}$ \\
\hline $\begin{array}{r}35 \\
938 \\
38 \\
39 \\
41\end{array}$ & $\begin{array}{l}\text { Withlacoochee River } \\
\text { near Holder } \\
\text { Blue Run at Dunnellon } \\
\text { Blue Run at Dunnellon } \\
\text { Withlacoochee River at Dunnellon } \\
\text { Withlacoochee River Bypass } \\
\text { Channel near Inglis }\end{array}$ & $\begin{array}{l}1979 \\
1981 \\
1979 \\
1981 \\
1979 \\
1981 \\
1979 \\
1981 \\
1979 \\
1981\end{array}$ & $\begin{array}{r}1,420 \\
382 \\
630 \\
564 \\
- \\
640 \\
- \\
1,080 \\
1,480 \\
680\end{array}$ & $\begin{array}{c}232 \\
340 \\
220 \\
234 \\
- \\
238 \\
237 \\
270 \\
216 \\
220\end{array}$ & $\begin{array}{l}7.2 \\
8.2 \\
7.6 \\
7.3 \\
7.8 \\
7.8 \\
7.4 \\
7.1 \\
7.2 \\
7.2\end{array}$ & $\begin{array}{r}24.0 \\
27.0 \\
23.0 \\
23.0 \\
24.0 \\
25.0 \\
24.5 \\
26.0 \\
27.0\end{array}$ & $\begin{array}{r}- \\
20 \\
0 \\
0 \\
- \\
5 \\
-5 \\
5 \\
35 \\
5\end{array}$ & $\begin{array}{c}120 \\
150 \\
56 \\
120 \\
- \\
110 \\
- \\
130 \\
110 \\
110\end{array}$ & $\begin{array}{c}44 \\
29 \\
7 \\
19 \\
- \\
16 \\
- \\
24 \\
21 \\
20\end{array}$ & $\begin{array}{c}42 \\
50 \\
17 \\
40 \\
- \\
37 \\
- \\
44 \\
38 \\
34\end{array}$ \\
\hline
\end{tabular}

${ }^{1}$ Cubic feet per second.

2 Micromhos per square centimeter at $25^{\circ} \mathrm{C}$.

3 Degrees Celsius.

${ }^{4}$ Platinum-cobalt units.

${ }^{5}$ Milligrams per 1iter as $\mathrm{CaCO}^{3}$. 
Withlacoochee River basin in May 1979 and April 1981

\begin{tabular}{|c|c|c|c|c|c|c|c|c|c|c|c|c|}
\hline $\begin{array}{l}\text { Map } \\
\text { No. }\end{array}$ & $\begin{array}{l}\text { Dis- } \\
\text { solved } \\
\text { magne- } \\
\text { sium }\end{array}$ & $\begin{array}{l}\text { Dis- } \\
\text { solved } 6 \\
\text { sodium }\end{array}$ & $\begin{array}{l}\text { Dis- } \\
\text { solved } \\
\text { potas } \\
\text { sium }\end{array}$ & $\begin{array}{l}\text { Dis- } \\
\text { solved } \\
\text { stronj } \\
\text { tium }\end{array}$ & $\begin{array}{l}\text { Dis- } \\
\text { solved } \\
\text { sul- } 6 \\
\text { fate }\end{array}$ & $\begin{array}{l}\text { Dis- } \\
\text { solved } \\
\text { chlo- } 6 \\
\text { ride }\end{array}$ & $\begin{array}{l}\text { Dis- } \\
\text { solved } \\
\text { fluo- } 6 \\
\text { ride }\end{array}$ & $\begin{array}{l}\text { Dis- } \\
\text { solved } \\
\text { silica }\end{array}$ & $\begin{array}{l}\text { Alka- } \\
\operatorname{lin}_{\overline{5}} \\
\text { ity }\end{array}$ & $\begin{array}{l}\mathrm{Bi-}- \\
\text { carbo } \\
\text { nate }\end{array}$ & $\begin{array}{l}\text { Dis- } \\
\text { solved } \\
\text { solids } \\
\text { residue } \\
\text { at } 180^{\circ} \mathrm{C}^{6} \\
\end{array}$ & $\begin{array}{l}\text { Dis- } \\
\text { solved } \\
\text { solids } \\
\text { sum of } \\
\text { constit } \\
\text { uents } \\
\end{array}$ \\
\hline 1 & $\begin{array}{l}2.0 \\
4.1\end{array}$ & $11^{7.3}$ & $\begin{array}{r}0.5 \\
.6\end{array}$ & $\begin{array}{r}90 \\
190\end{array}$ & $\begin{array}{l}7.2 \\
1.0\end{array}$ & $\begin{array}{c}14 \\
1.9\end{array}$ & $\begin{array}{r}0.1 \\
.2\end{array}$ & $\begin{array}{l}4.9 \\
1.6\end{array}$ & $\begin{array}{r}33 \\
149\end{array}$ & $\begin{array}{r}40 \\
182\end{array}$ & $\begin{array}{l}146 \\
224\end{array}$ & $\begin{array}{r}74 \\
184\end{array}$ \\
\hline \multirow{2}{*}{3} & - & & - & - & & & $\ddot{-}$ & $\because$ & - & - & - & - \\
\hline & 6.2 & 19 & 6.9 & 320 & 28 & 13 & .2 & 6.2 & 139 & 170 & 218 & 209 \\
\hline 4 & - & - & - & - & - & - & - & - & - & - & - & - \\
\hline \multirow[b]{2}{*}{8} & 4.0 & 11 & .7 & 160 & - & 17 & .3 & .4 & 141 & 172 & 210 & - \\
\hline & - & $3^{-}$ & - & - & - & - & - & - & $\overline{0}$ & - & - & - \\
\hline \multirow{2}{*}{11} & 4.6 & 13 & 1.6 & 260 & $\overline{-}$ & 17 & -3 & $: 6$ & 131 & 160 & 192 & - \\
\hline & 4.0 & 8.2 & 1.1 & 320 & 8.0 & - & .2 & 4.1 & 177 & 216 & 224 & 210 \\
\hline \multirow[t]{2}{*}{14} & - & - & - & - & - & - & - & - & - & - & - & - \\
\hline & 3.9 & 7.8 & 1.0 & 360 & 9.3 & 5.0 & .1 & 1.0 & 154 & 188 & 203 & 179 \\
\hline 17 & $\overline{3.6}$ & 8.7 & $\overline{1} 3$ & $\overline{250}$ & $\overline{7} 8$ & $13^{-}$ & - & - & $\overline{26}$ & $\overline{5}$ & $\overline{-}$ & - \\
\hline \multirow{2}{*}{19} & - & $\because$ & $\because$ & - & - & 10 & $\because 1$ & 1.0 & 126 & 154 & 170 & 160 \\
\hline & 3.6 & 8.9 & 1.4 & 220 & 8.8 & 11 & .1 & .8 & 117 & 143 & 167 & 148 \\
\hline 21 & - & - & - & - & - & & - & - & - & - & - & - \\
\hline \multirow{3}{*}{23} & 4.0 & 9.8 & 3.5 & 220 & 10 & 13 & .2 & 1.9 & 108 & 132 & 166 & 146 \\
\hline & - & - & - & - & - & - & - & - & - & - & - & - \\
\hline & 2.3 & 6.6 & .2 & 110 & 2.9 & 11 & .3 & 5.1 & 185 & 226 & 218 & 215 \\
\hline \multirow[t]{2}{*}{$25 \mathrm{~A}$} & 4.0 & 4.0 & .2 & 250 & 33 & 7.8 & .1 & 3.9 & 59 & 72 & 155 & 121 \\
\hline & 5.2 & 5.0 & 2.4 & 430 & 30 & 9.4 & .2 & 4.8 & 77 & 94 & 157 & 140 \\
\hline \multirow[t]{2}{*}{28} & - & - & - & - & - & - & - & - & - & - & - & - \\
\hline & 4.9 & 5.8 & .4 & 390 & 39 & 5.2 & .2 & 1.8 & 80 & 98 & 181 & 143 \\
\hline 31 & 5.7 & 3.7 & .3 & $\overline{300}$ & $16^{-}$ & $11^{-}$ & - & 5.4 & $\overline{130}$ & $\overline{158}$ & $\overline{182}$ & $\overline{171}$ \\
\hline \multirow[t]{2}{*}{33} & $\because$ & $\because$ & - & - & & 11 & $\because$ & -8 & - & - & 102 & 17 \\
\hline & 5.6 & 5.7 & $:^{4}$ & 430 & 37. & 9.4 & $:^{2}$ & 4.0 & 99 & 121 & 198 & 168 \\
\hline 34 & 6.0 & 3.5 & .2 & 460 & 30 & 5.4 & .1 & 6.2 & 121 & 146 & 189 & 174 \\
\hline 35 & 3.8 & 3.9 & .2 & - & 36 & 6.7 & .1 & 5.5 & 77 & - & 182 & 145 \\
\hline & 5.3 & 5.0 & .4 & 410 & 36 & 8.0 & .2 & 3.0 & 118 & 144 & 231 & 179 \\
\hline${ }^{9} 38$ & 3.3 & 2.0 & .1 & 40 & 4.0 & 3.2 & 0 & 7.0 & 49 & 60 & 73 & 66 \\
\hline & 5.0 & 2.7 & .6 & 250 & 16 & 5.0 & .3 & 6.8 & 102 & 124 & 112 & 138 \\
\hline \multirow{2}{*}{38} & 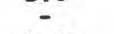 & $\because$ & - & - & - & - & - & - & - & - & - & - \\
\hline & 4.6 & 2.8 & .1 & 250 & 15 & 2.1 & .2 & 3.9 & 96 & 117 & 132 & 124 \\
\hline \multirow[t]{2}{*}{39} & - & - & - & - & - & - & - & - & - & - & - & - \\
\hline & 5.0 & 3.6 & .2 & 300 & 22 & 5.8 & .2 & 2.3 & 107 & 130 & 152 & 147 \\
\hline \multirow[t]{2}{*}{41} & 3.9 & 3.5 & .1 & 200 & 20 & 6.0 & .1 & 6.0 & 90 & 110 & 154 & 132 \\
\hline & 5.1 & 3.2 & .5 & 200 & 21 & 5.6 & .3 & 7.0 & 86 & 105 & 104 & 129 \\
\hline
\end{tabular}

6 Milligrams per liter.

${ }^{7}$ Micrograms per liter.

8 Milligrams per liter as $\mathrm{HCO}^{3}$.

${ }^{9}$ Data for Rainbow Springs near Dunnellon 2323100 ), May 1979 and May 1981. 


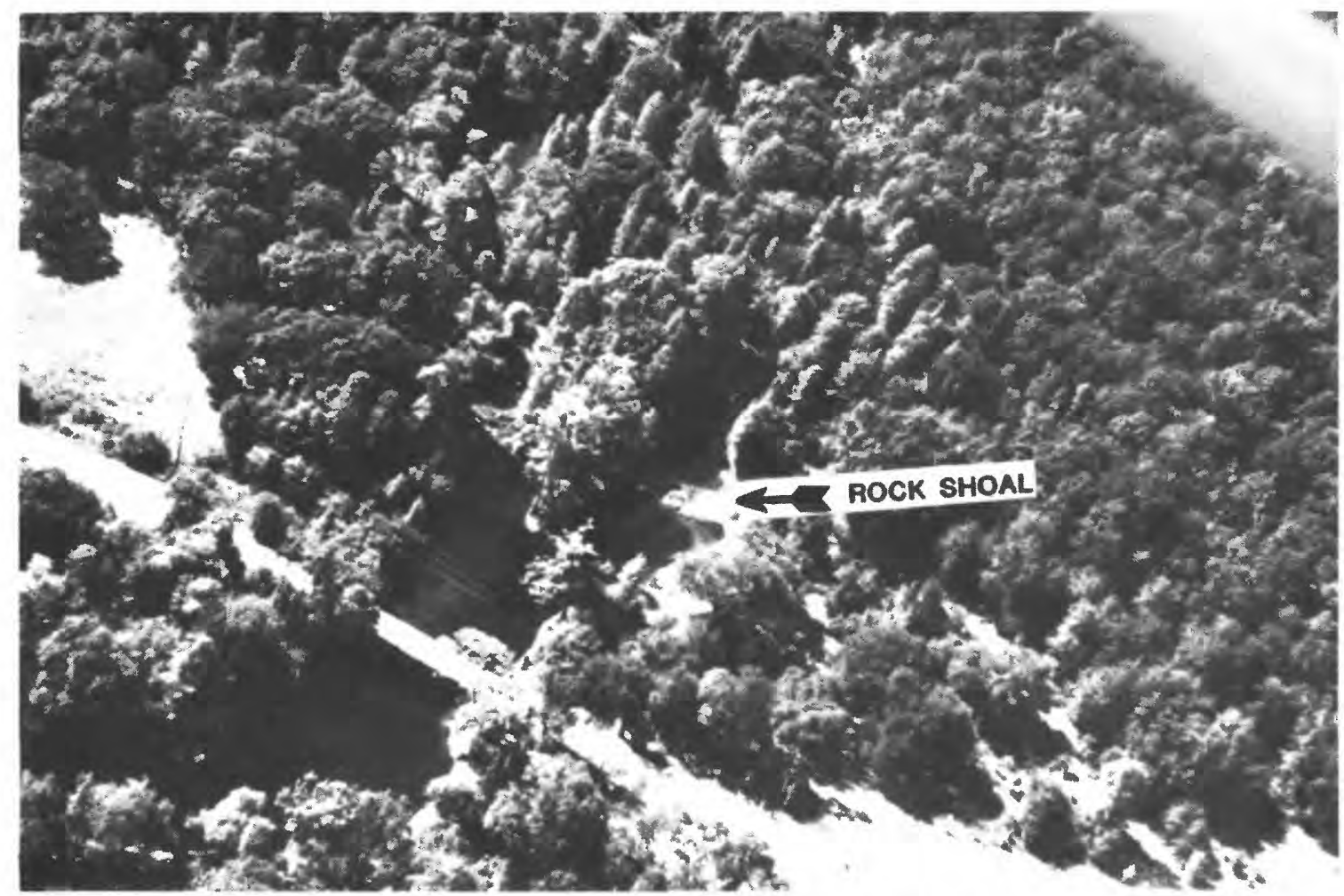

Figure 9.--Withlacoochee River near Dade City (site 1). (River Road bridge and rock shoal about 200 feet upstream from bridge. June 26, 1981.)

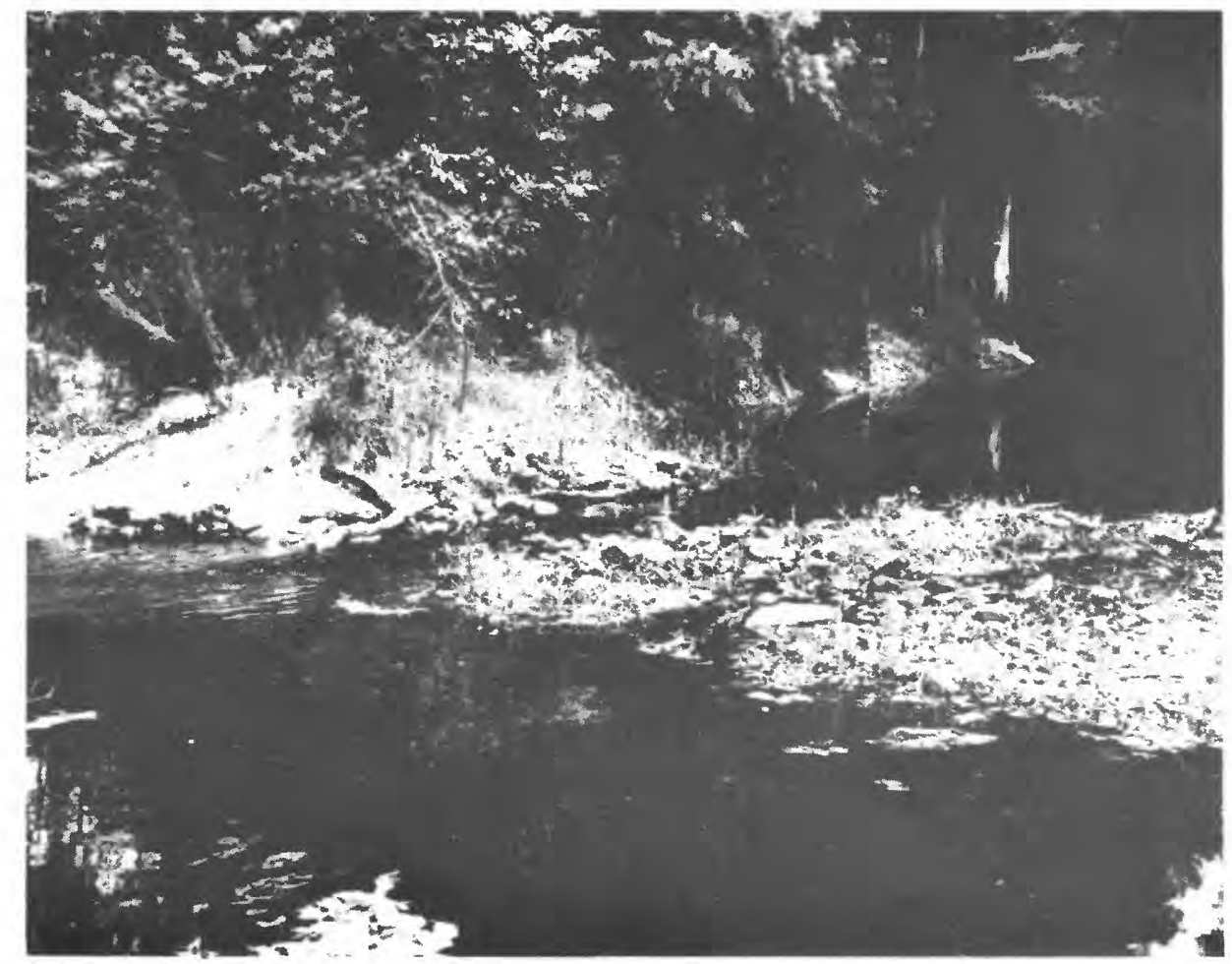

Figure 10.--Withlacoochee River near Dade City (site 1). (Rock shoal about 200 feet upstream. Estimated discharge 10 cubic feet per second, stage 68.63 feet. July 2, 1981.) 


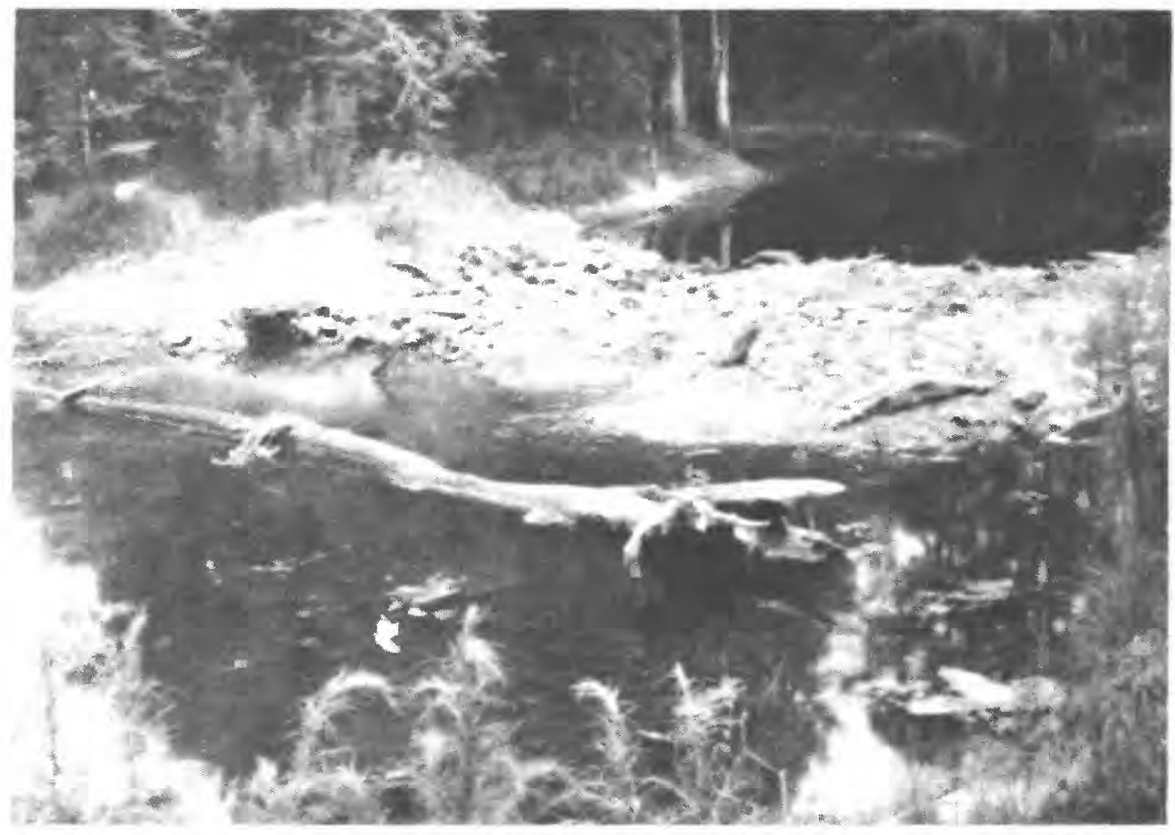

Figure 11.--Withlacoochee River near Dade City (site 1). (Rock shoal about 200 feet upstream from River Road and staff gage. Estimated discharge, 0.2 cubic foot per second. Stage, 67.38 feet. Flow filtering through rocks. June 19, 1981.)

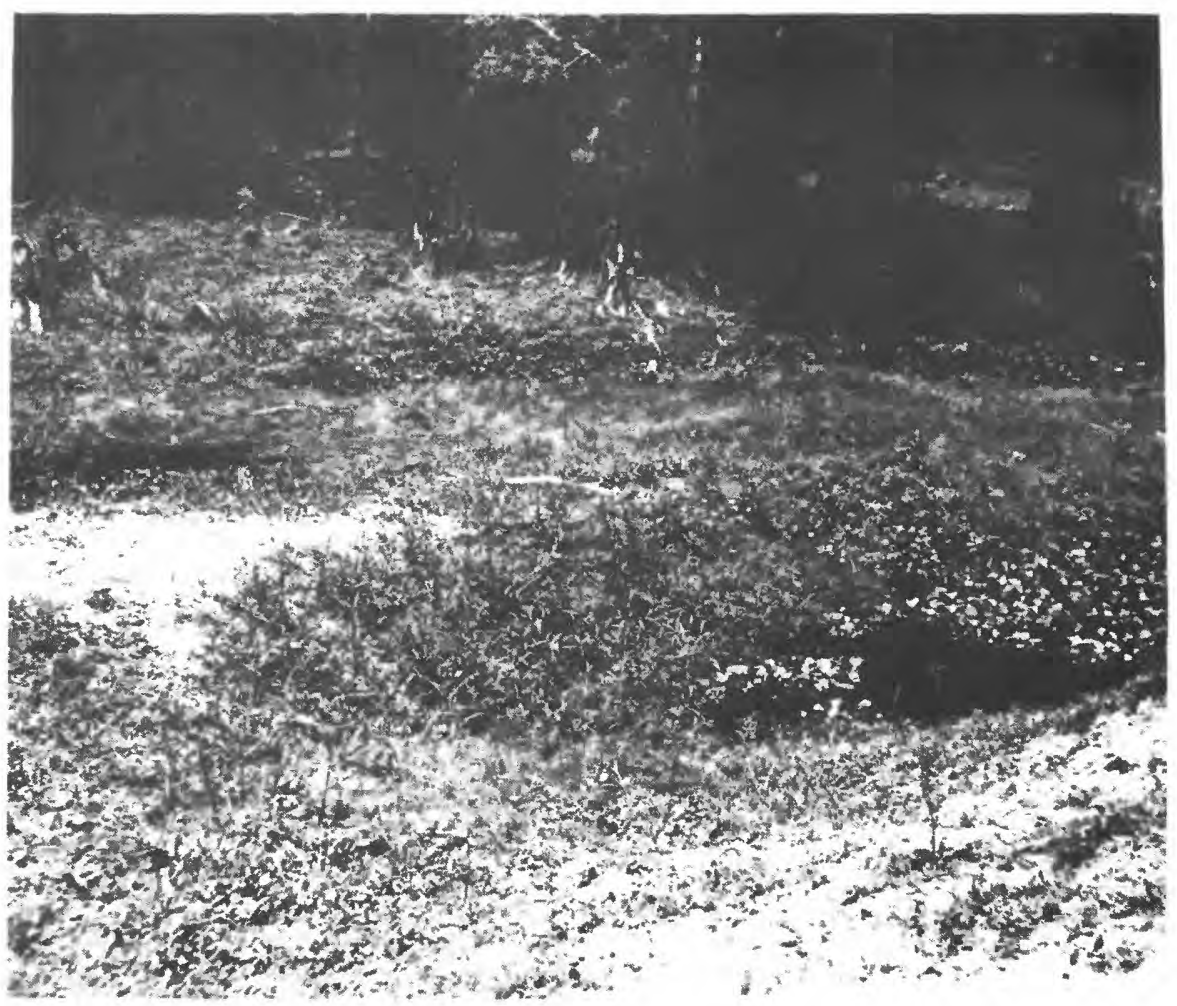

Figure 12.--Withlacoochee River low-water channel above Dobes Hole near Lacoochee (site 2). (Dry river bed. July 2, 1981.) 


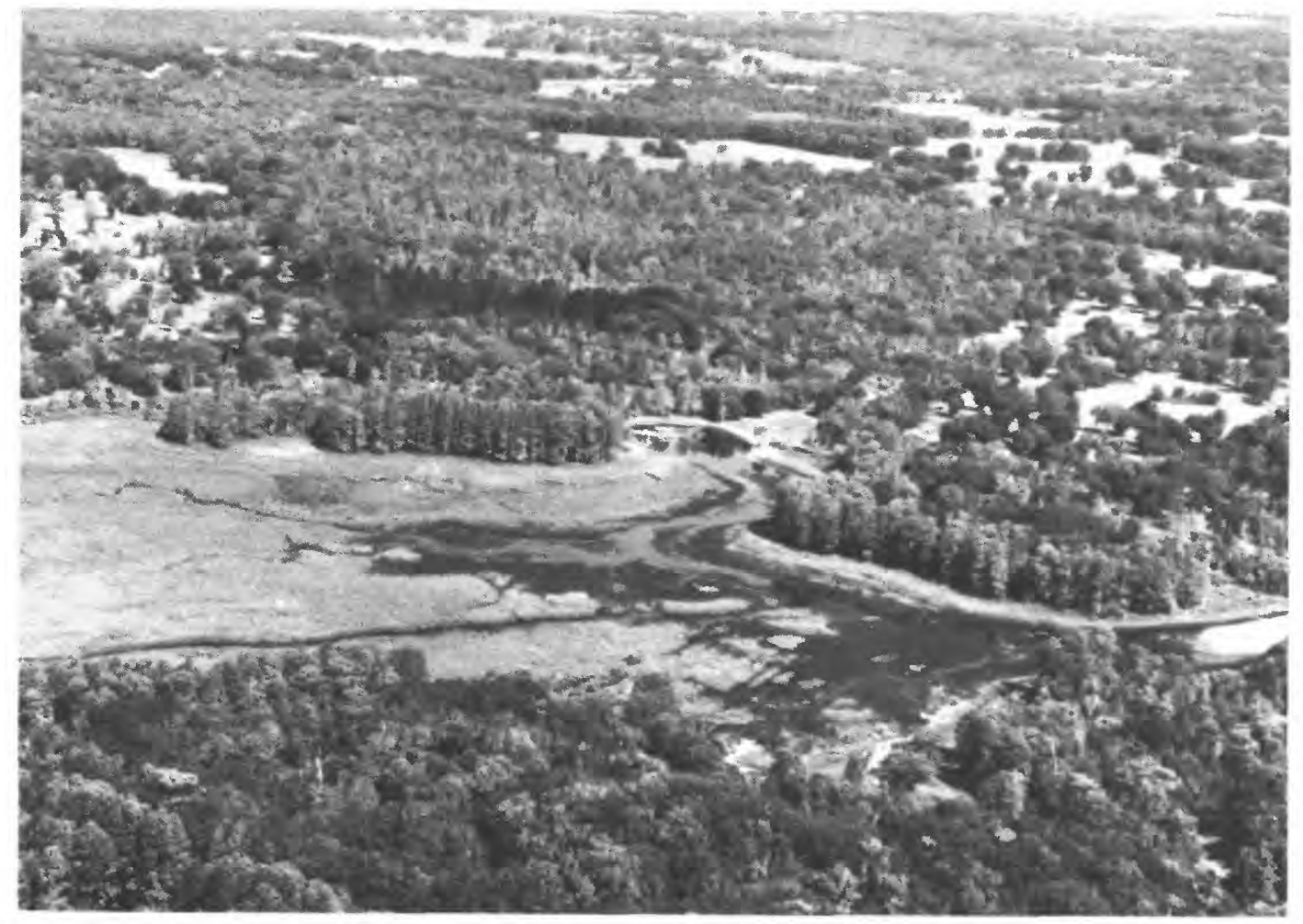

Figure 13.--Dobes Hole prairie near Lacoochee looking northwest. (Dobes Hole at center. Canal inflow, left center. River inflow, lower left. River outflow, right. June 26, 1981.)

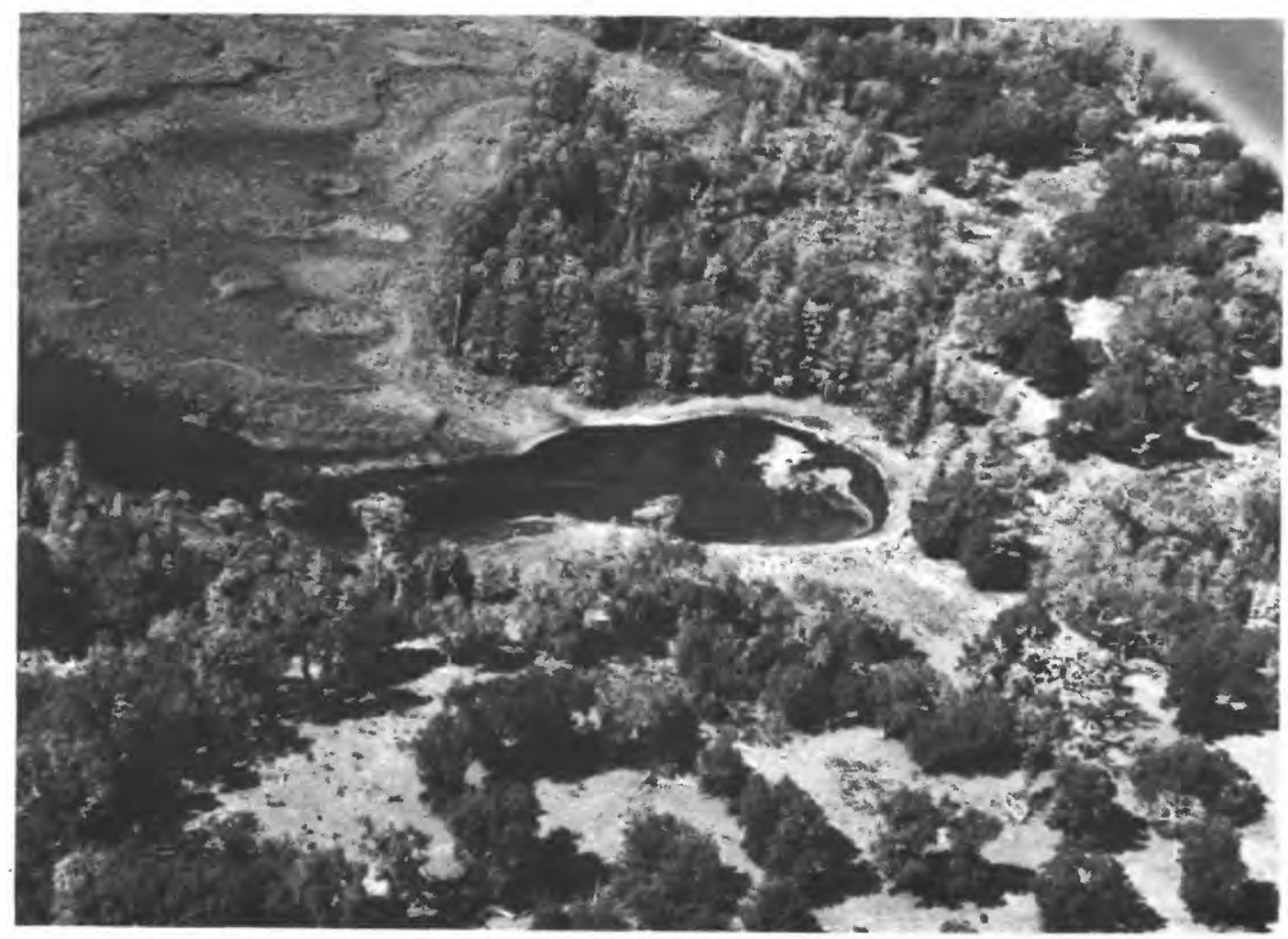

Figure 14.--Dobes Hole near Lacoochee view from the north. (Canal inflow, upper left. June 26, 1981.) 


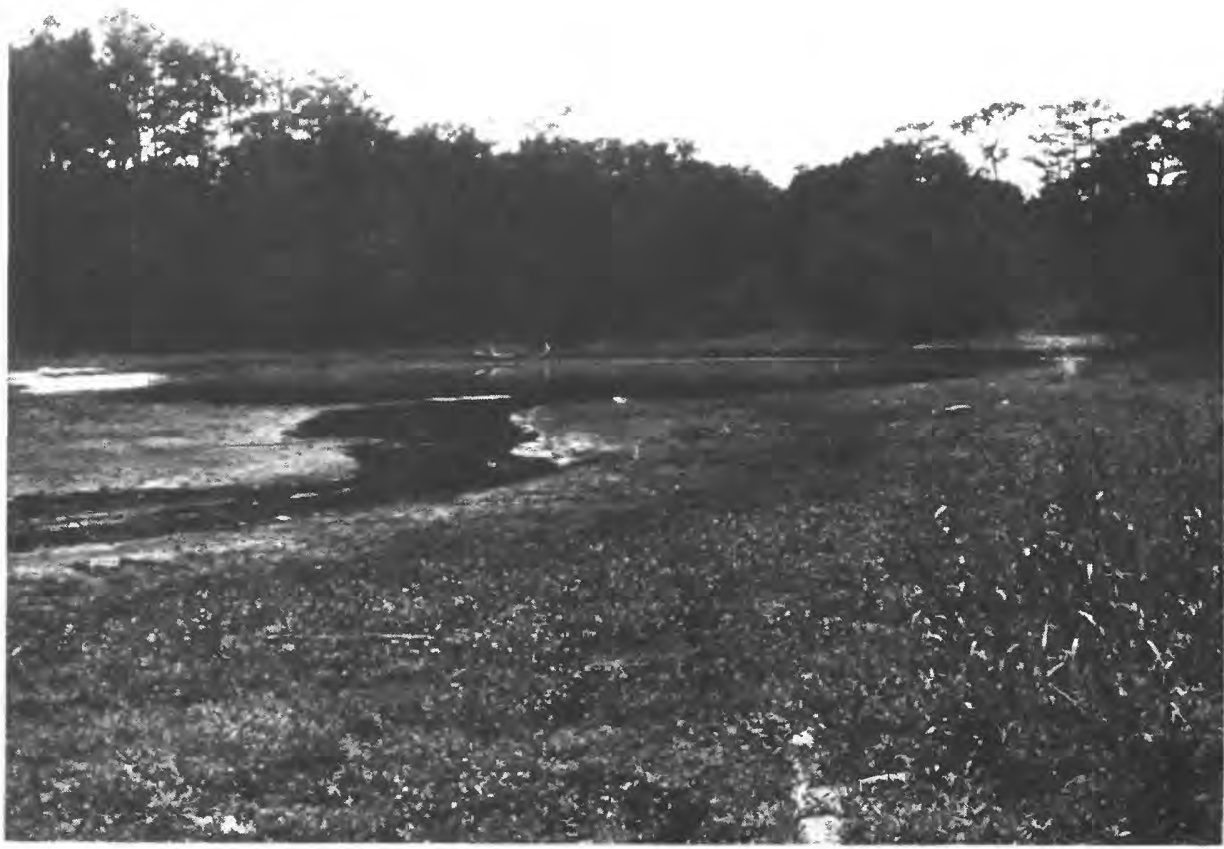

Figure 15.--Dobes Bole near Lacoochee (site 6). (Looking across to west end of Dobes Hole.)

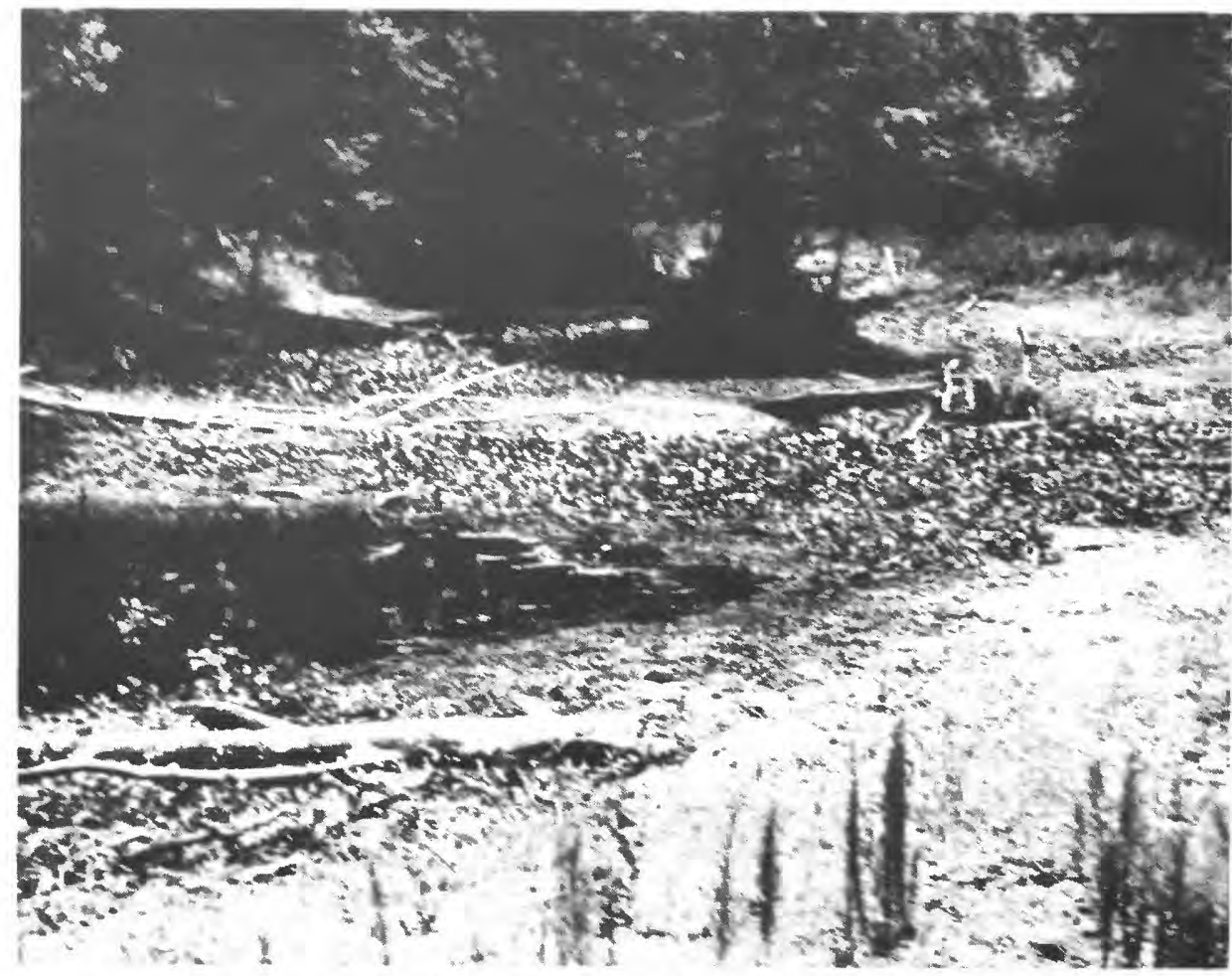

Figure 16.--Dobes Hole outlet near Lacoochee (site 7). (Looking north at edge of ponded water and hyacinth-covered dry sandbar across channel; another small pond of water and then continuous dry riverbed into background. July 2, 1981.) 


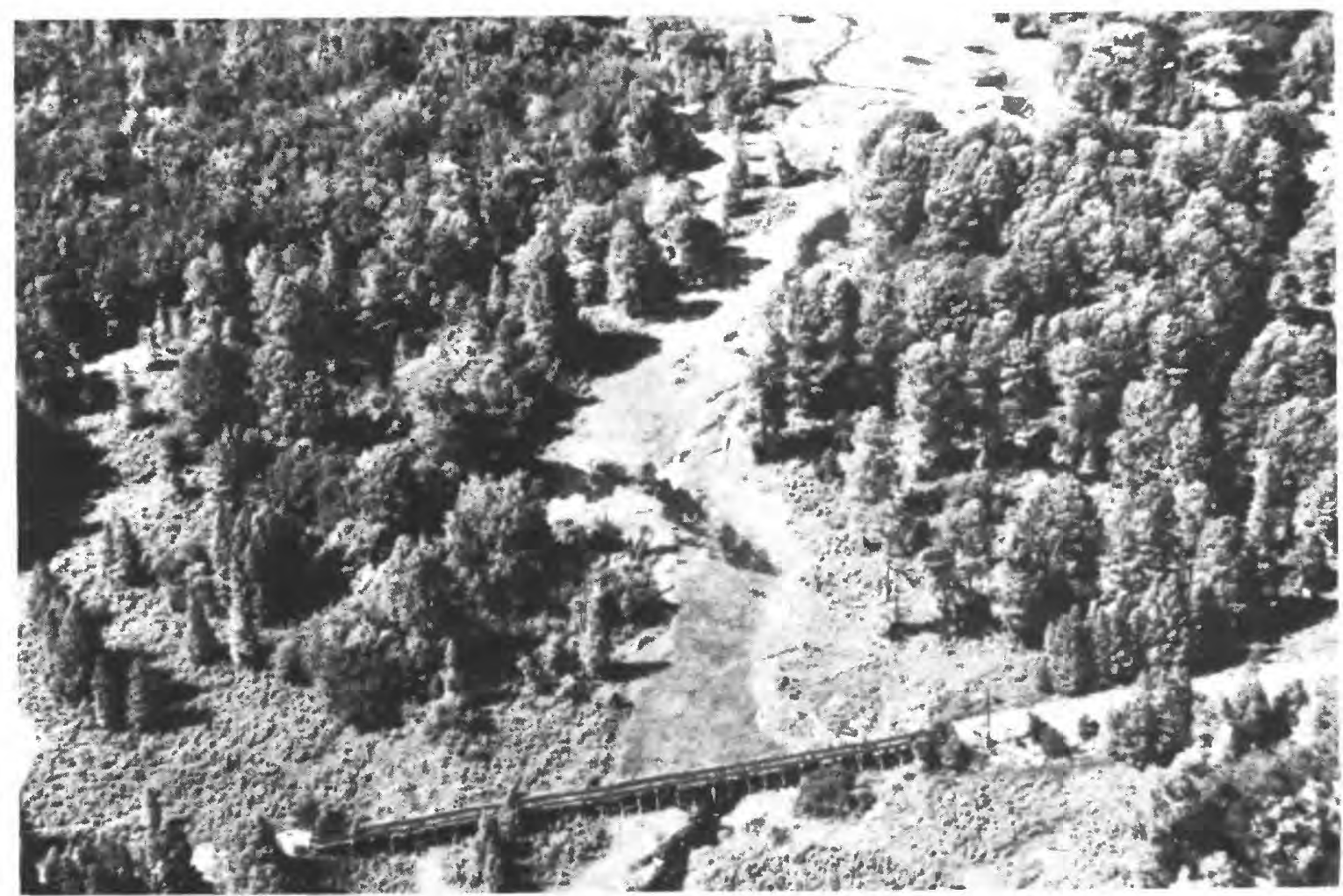

Figure 17.--Withlacoochee River near Lacoochee (site 8). (Looking upstream (south) across Main Line Road bridge at nearly dry riverbed. June $26,1981$.

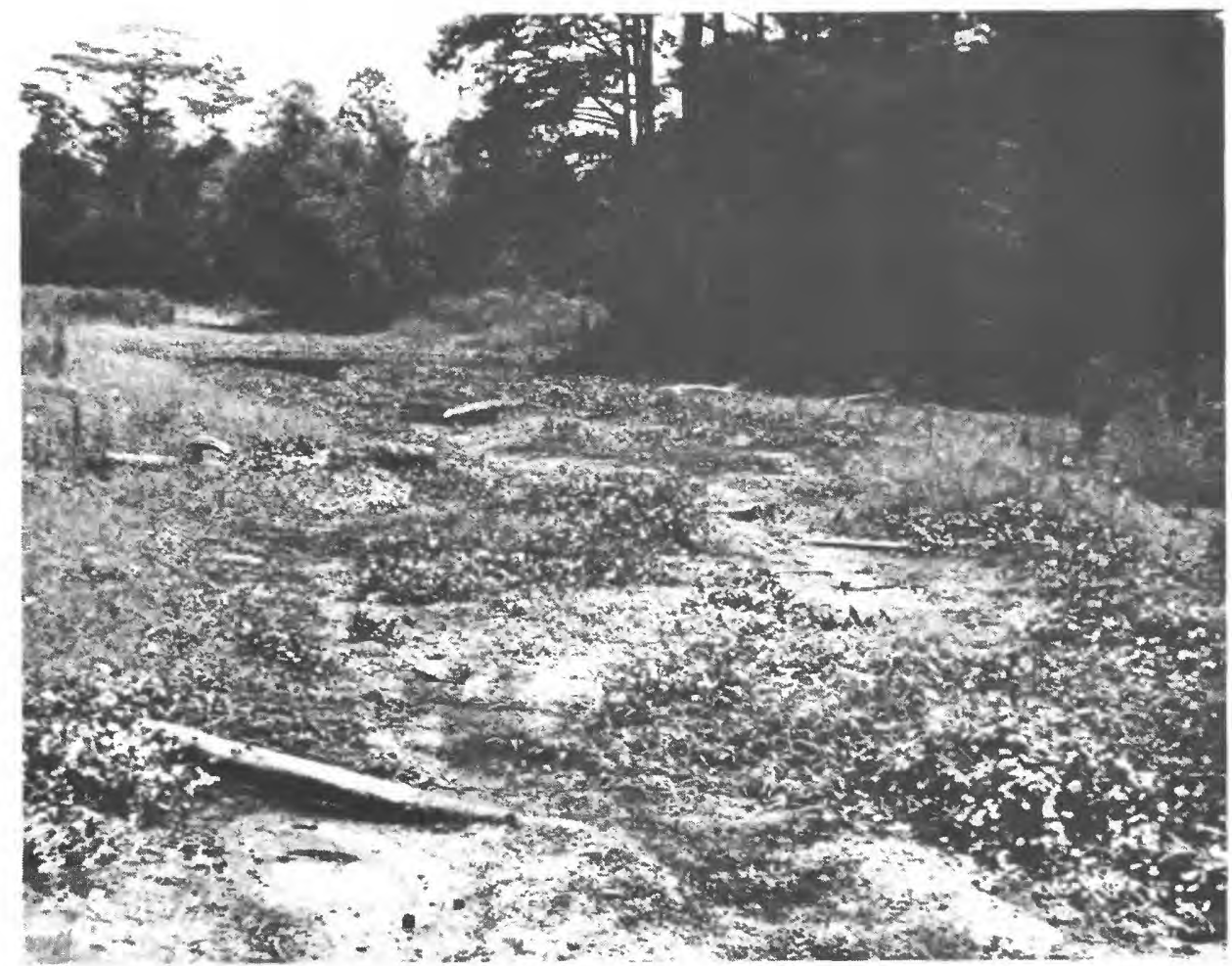

Figure 18.--Withlacoochee River near Lacoochee (site 8), (Note puddle just downstream of log in foreground. July 2, 1981.) 


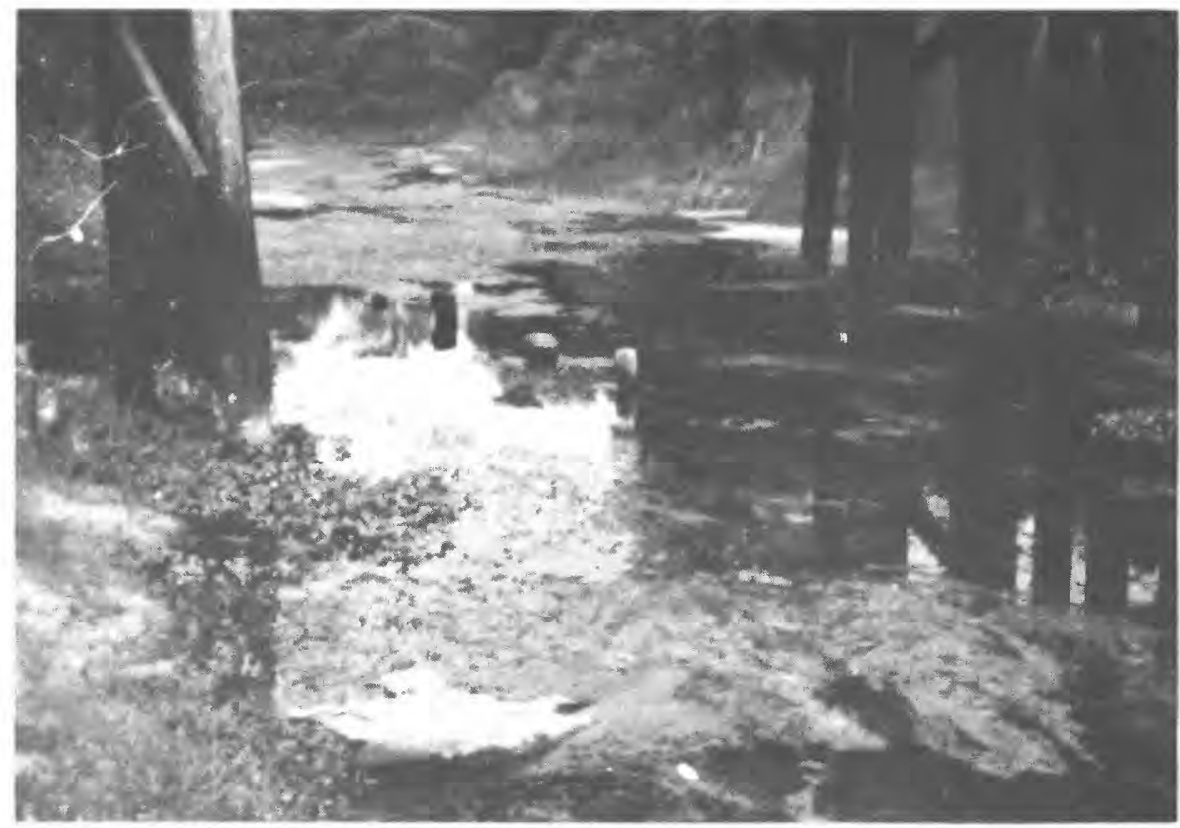

Figure 19.--Withlacoochee River at Trilby (site 11). (Looking upstream from near gage at dense weeds in channel upstream from bridge. Discharge, 6.3 cubic feet per second. Stage, 50.09 feet. Flow is ground-water effluence between sites 8 and 11 . June 19, 1981.)

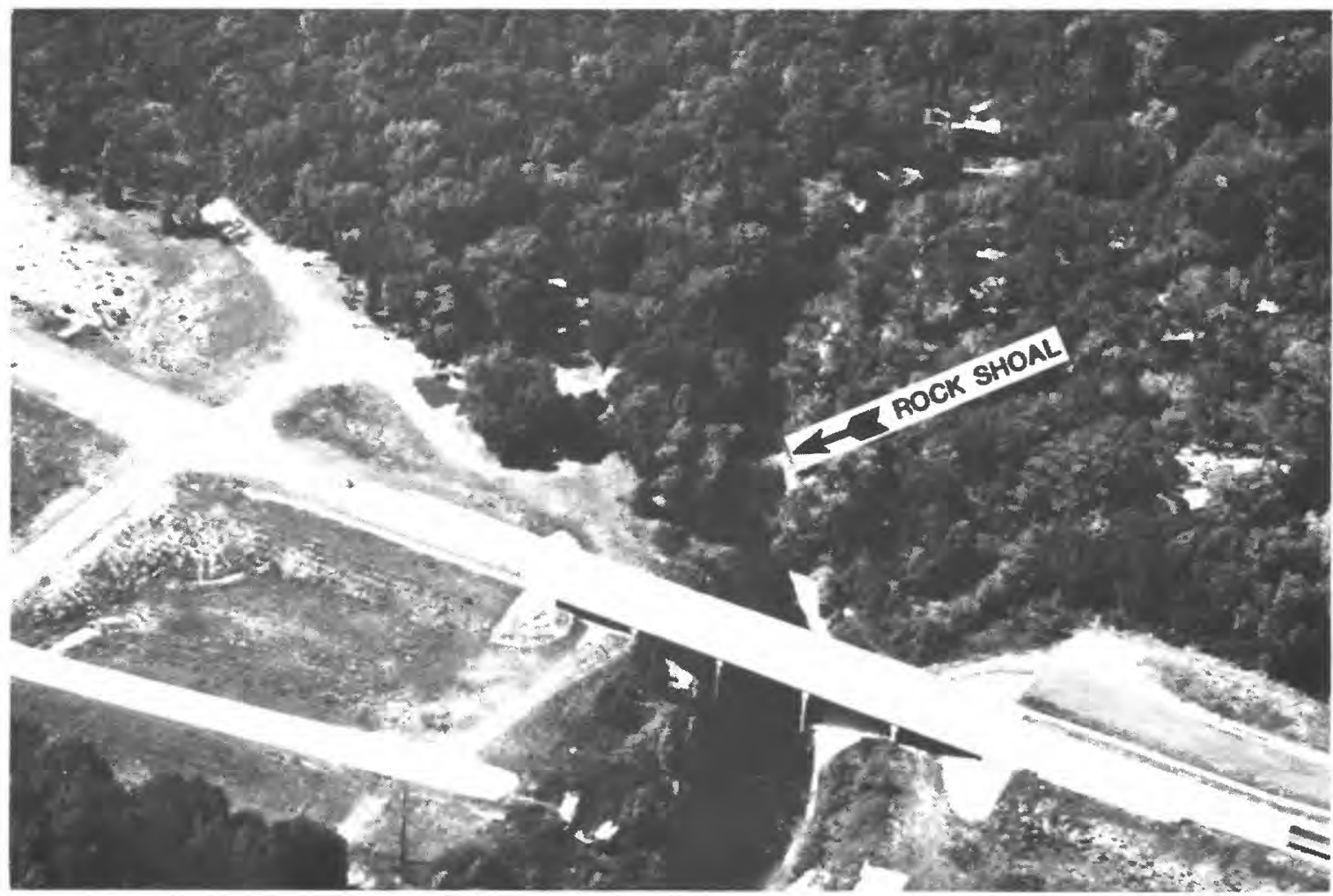

Figure 20.--Withlacoochee River at Rital (site 14). (Looking upstream across State Highway 50 bridge toward rock shoal. June 26, 1981.) 


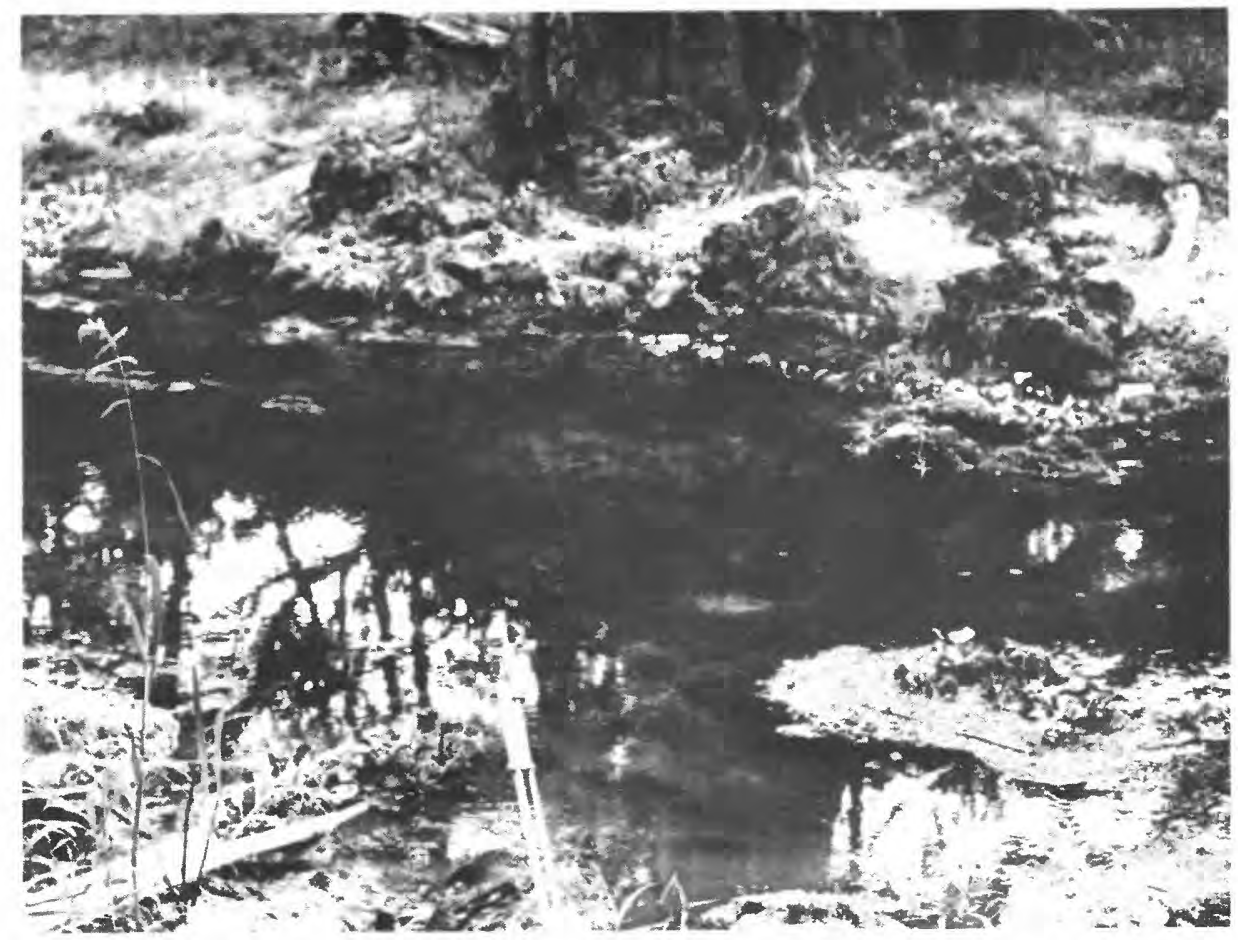

Figure 21.--Withlacoochee River at Rital (site 14). (Rock shoal 500 feet upstream from State Highway 50 bridge. Discharge 2.9 cubic feet per second. Stage, 43.63 feet. July 7, 1981.)

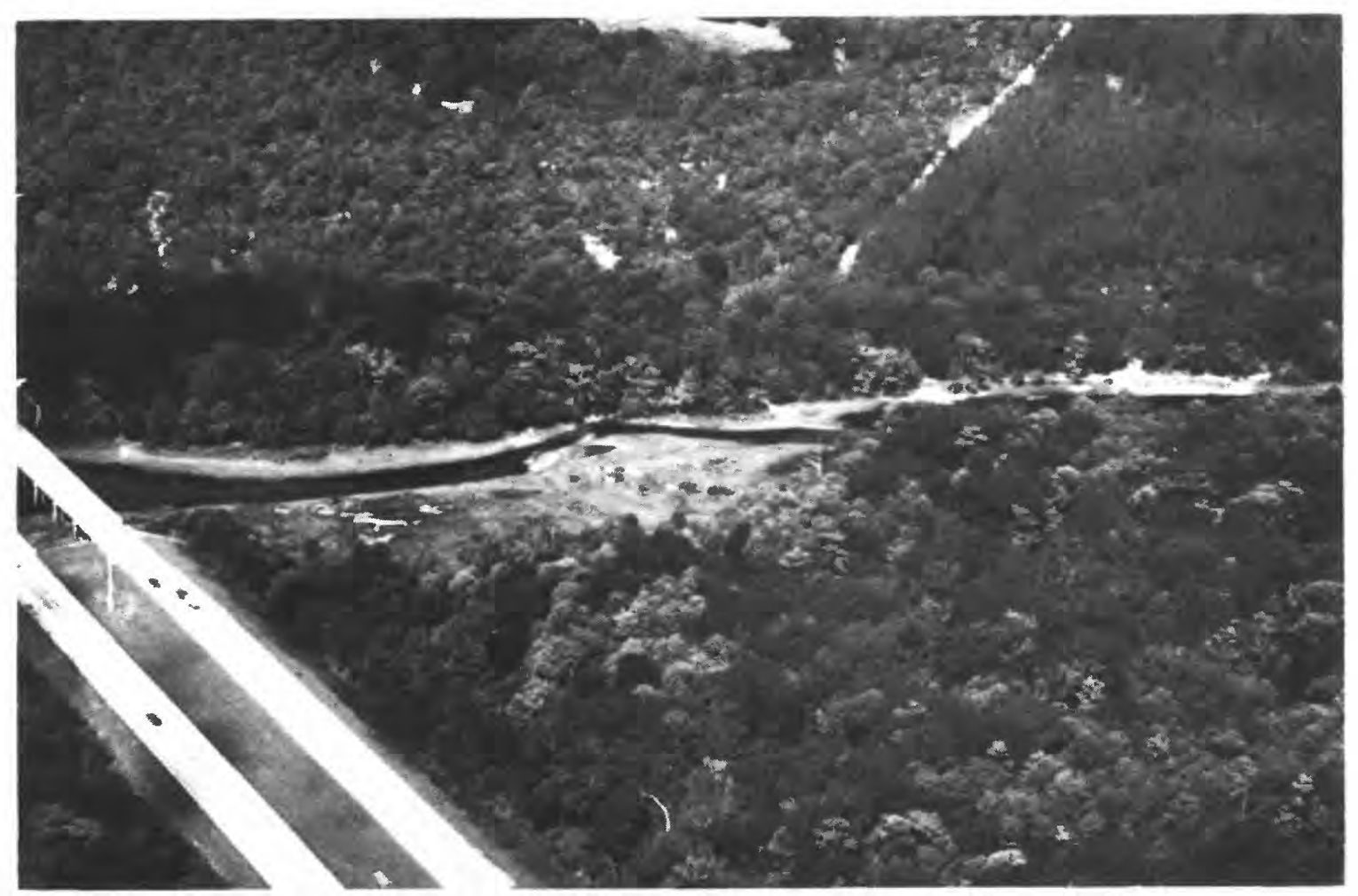

Figure 22.--Withlacoochee River at outlet of Silver Lake downstream from Interstate Highway 75 bridge. (Discharge about 6 cubic feet per second. Stage, about 40.5 feet. June 26, 1981. Average discharge about 380 cubic feet per second, median about 190 cubic feet per second. Median stage, about 3 feet higher.) 


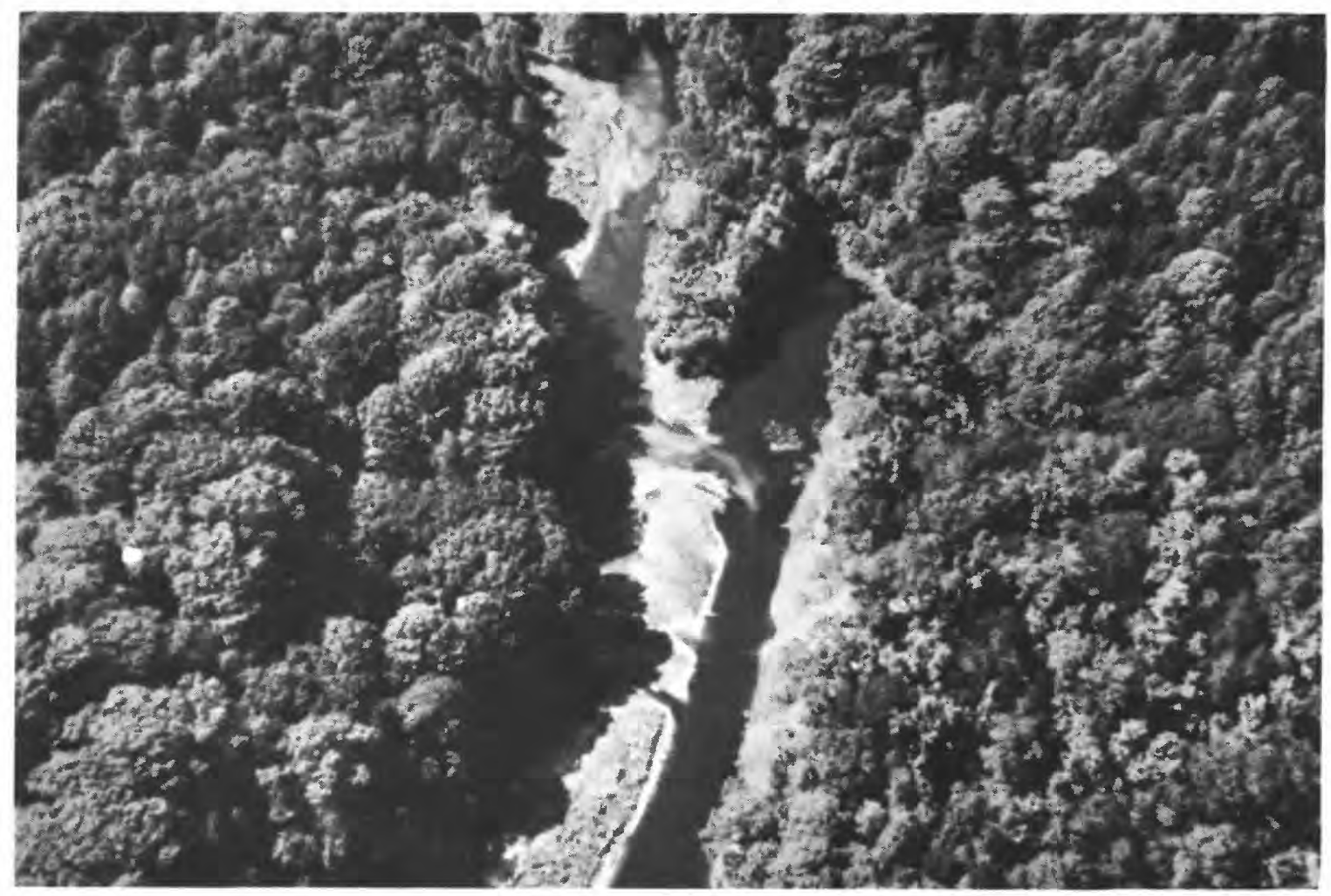

Figure 23.--Withlacoochee River at low-water control, 6,600 feet downstream from Croom (site 17). (Discharge, 6.0 cubic feet per second. Stage 40.13 feet. June 26, 1981.)

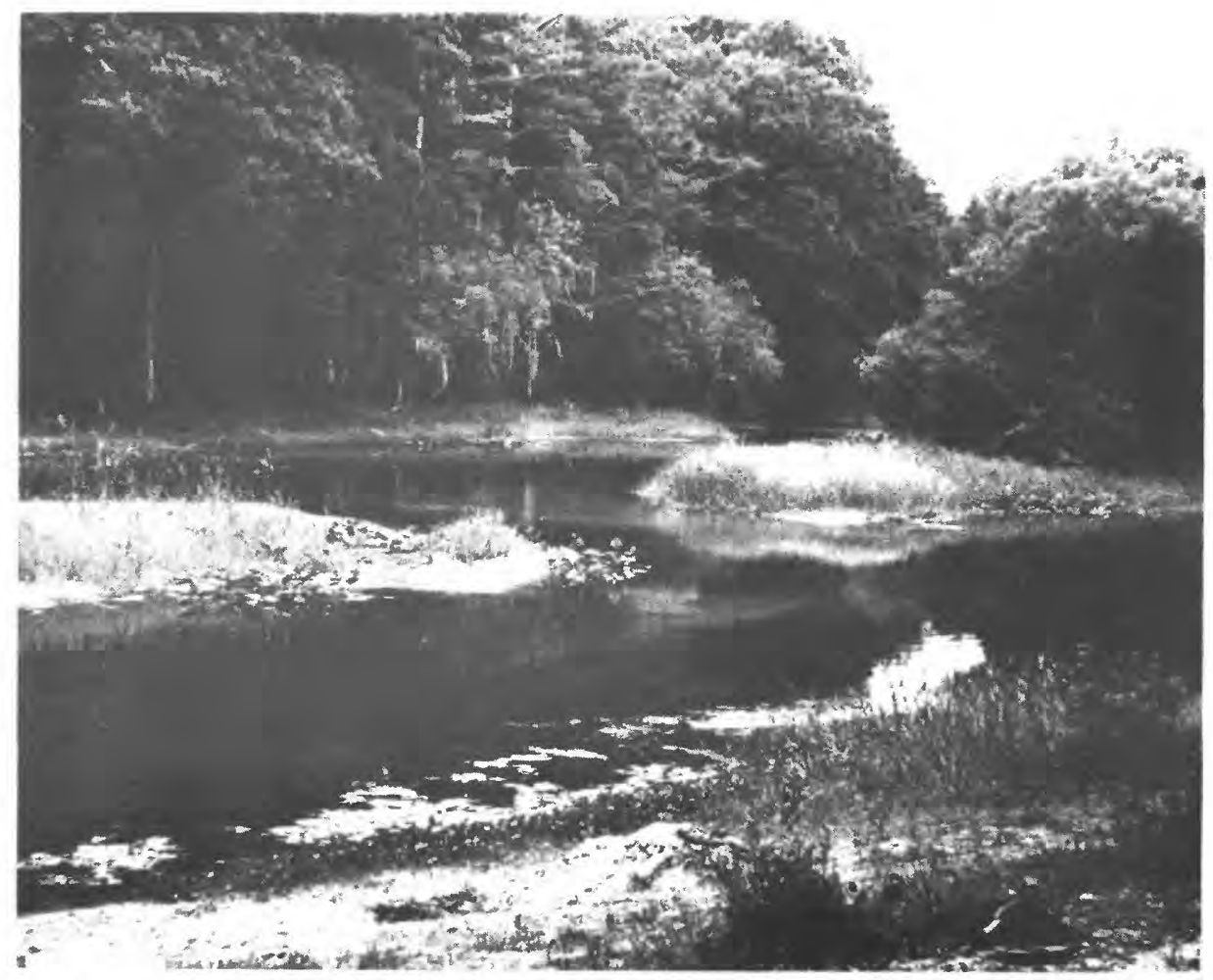

Figure 24.--Withlacoochee River at low-water control, 6,600 feet downstream from Croom (site 17). (Discharge, 5.2 cubic feet per second. Stage, 40.07 feet. July 2, 1981. Median discharge 225 cubic feet per second; stage, 42.8 feet.) 


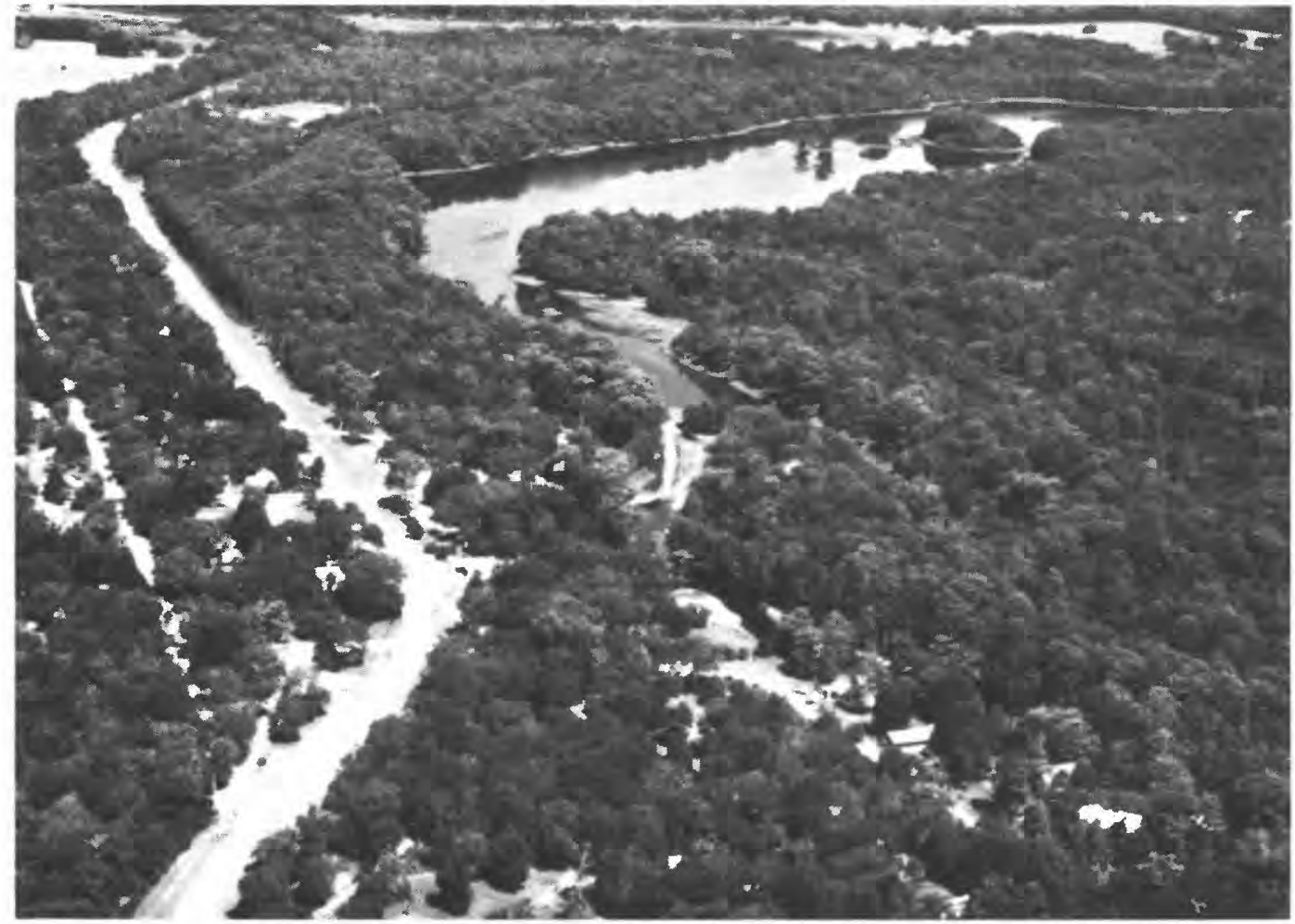

Figure 25.--Withlacoochee River at Nobleton (site 19). (Looking west (downstream) along left channel. Light strip at center is low-water sandbar control. June 26, 1981.)

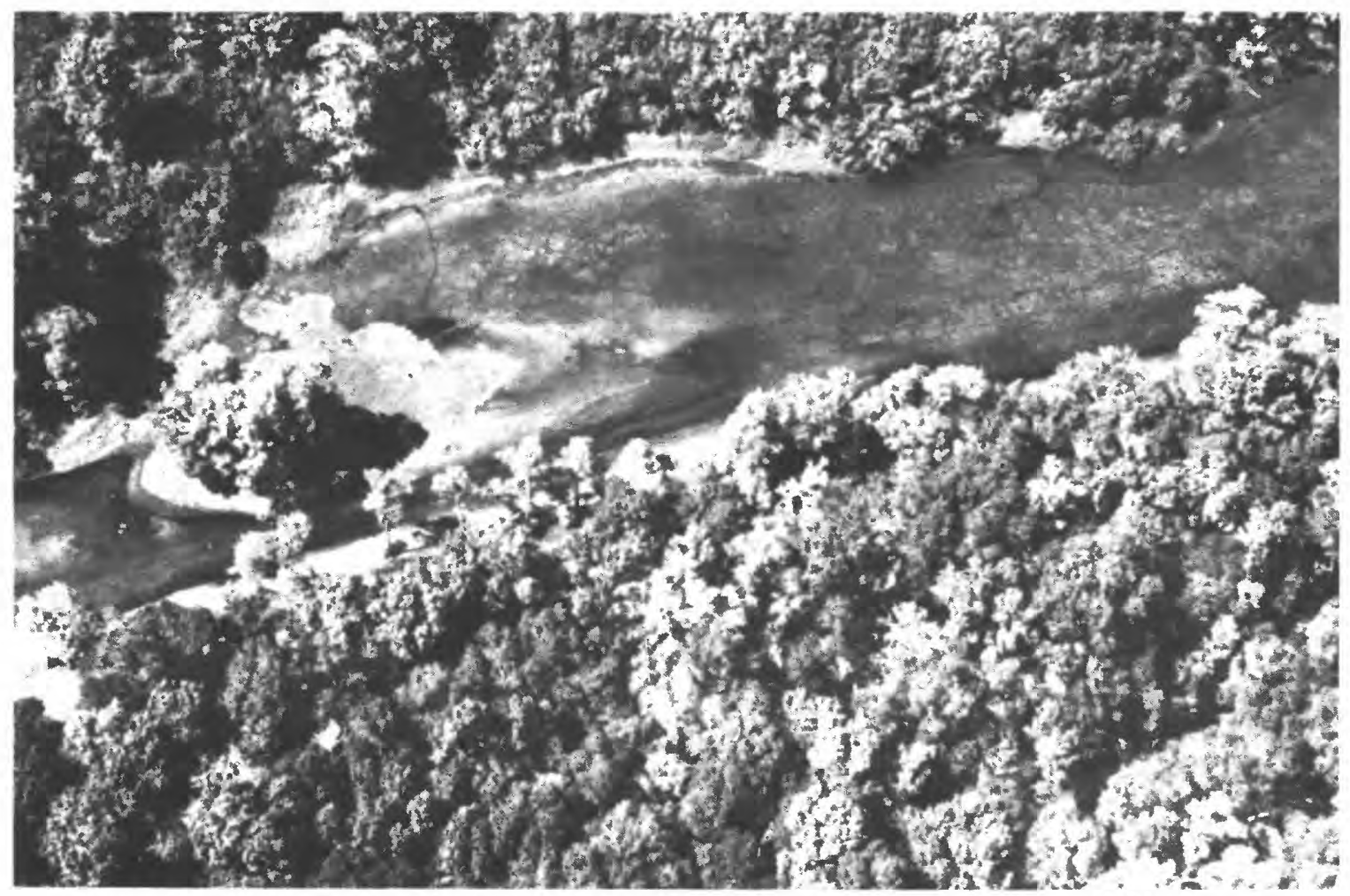

Figure 26.--Withlacooches River at Nobleton (site 19). (Looking west across right channel. Low-water control at tip of light tree left of center of photograph. June 26, 1981.) 


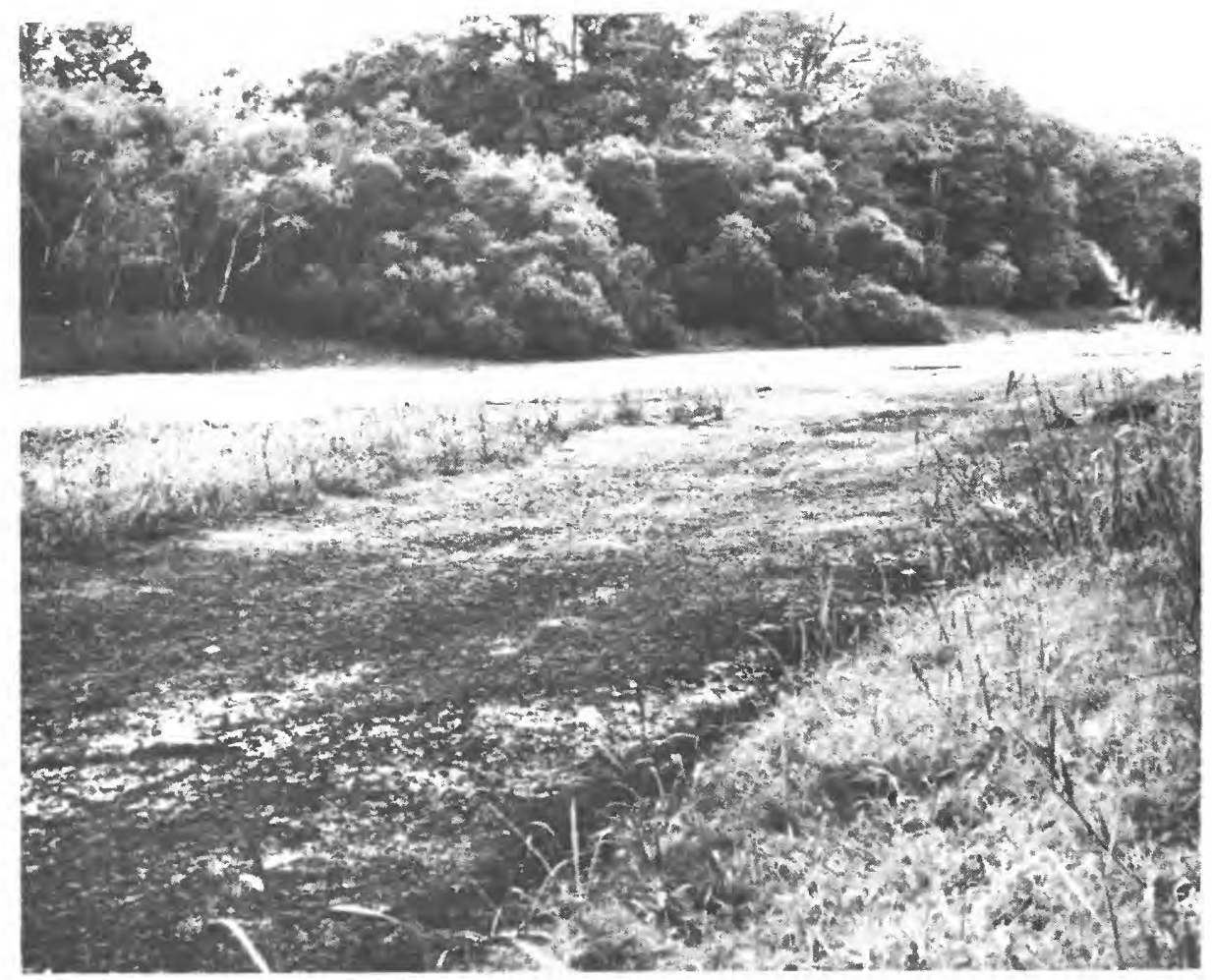

Figure 27.--Withlacoochee River at Nobleton (site 19). (Closeup of right channel control. July 2, 1981.)

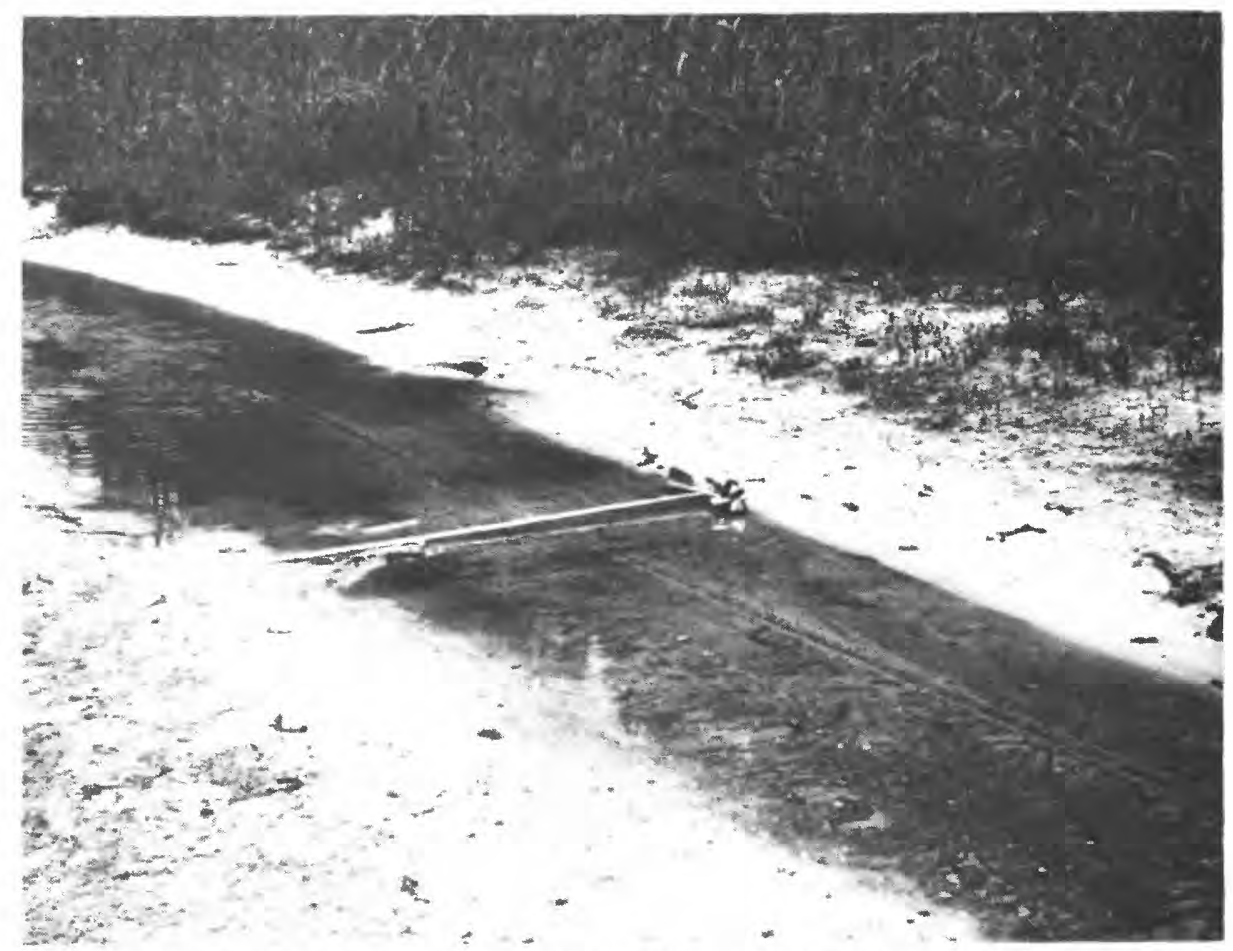

Figure 28.--Withlacoochee River at Nobleton (site 19). (Closeup of wading rod spanning low-water channel at control. Estimated discharge, 0.1 cubic foot per second. Stage, 37.76 feet. July 7 , 1981. Channel was 3 feet wide and 0.1 foot deep. Velocity 0.3 cubic foot per second. This is the net surface runoff from approximately one-half of the Withlacoocheo River basin on this date.) 


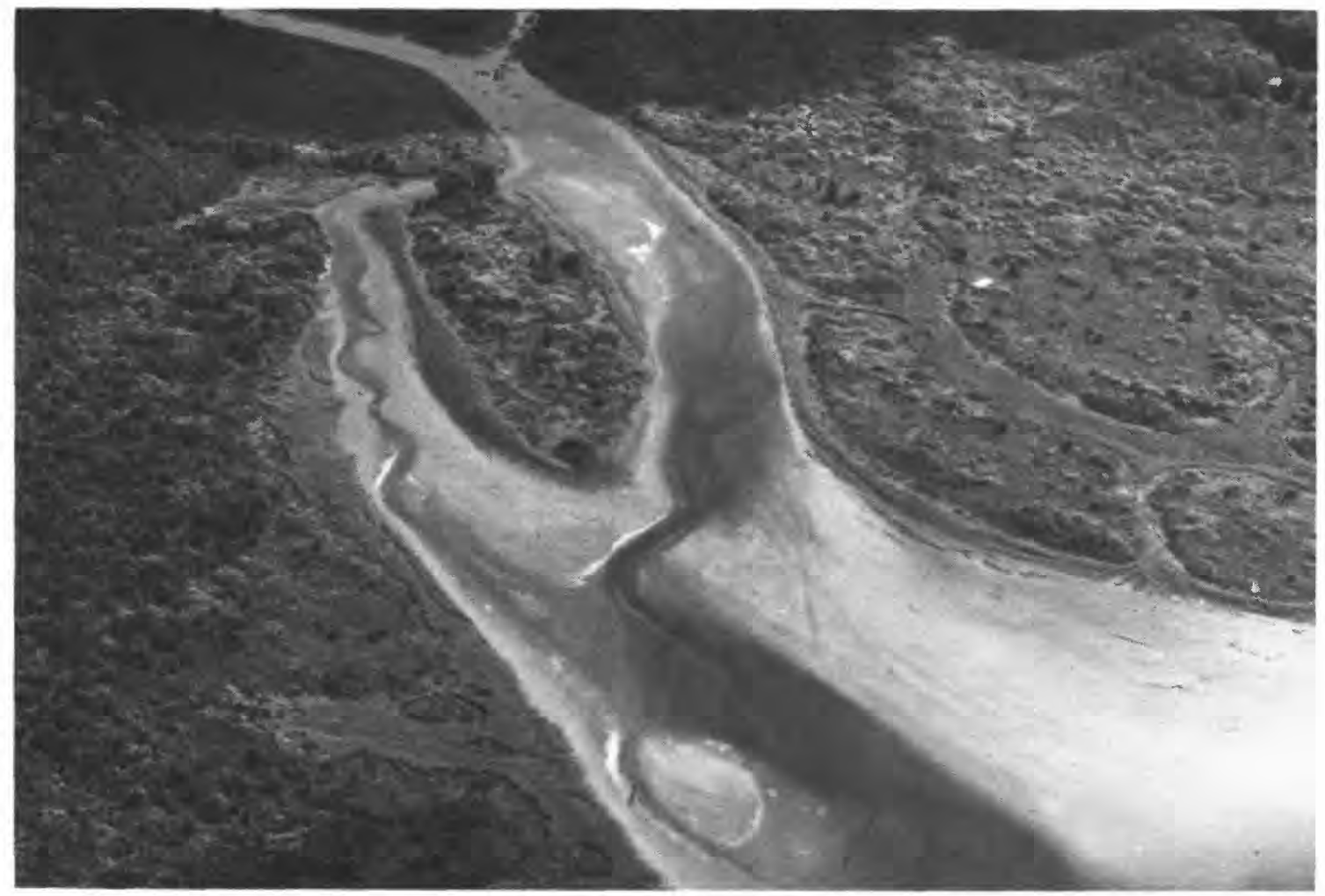

Figure 29.--Lake Panasoffkee near Lake Panasoffkee (site 25). (Mudflats at north end of lake. Stage, 37.92 feet. June 26, 1981. Median stage about 3 feet higher. Minimum stage in 1981, 37.81 feet July 16. Minimum stage of record, 37.65 feet May 12, 1962.)

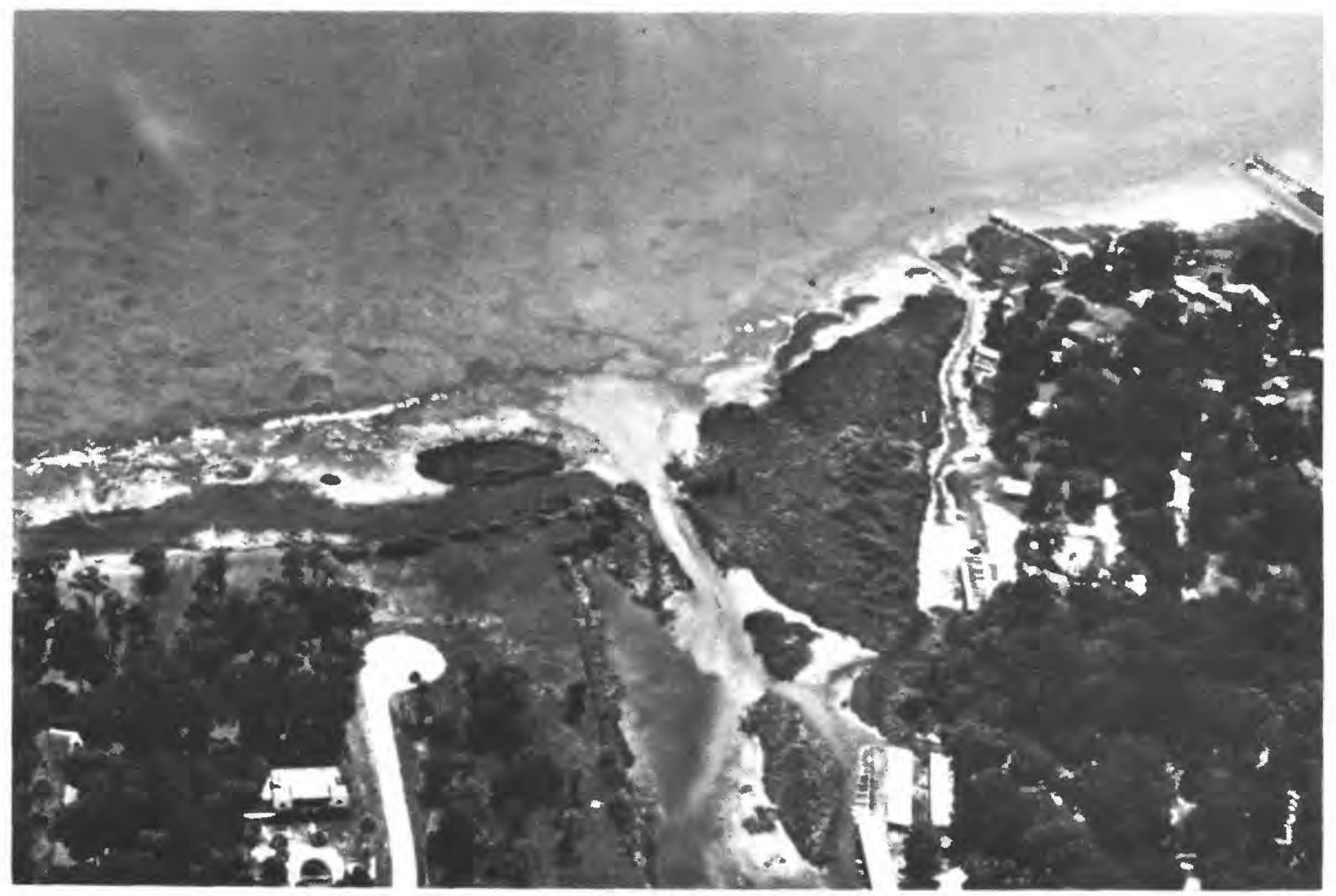

Figure 30.--Head of Outlet River at Panacoochee Retreats (site 25A) at outlet of Lake Panasoffkee near Lake Panasoffkee (site 25). (Lake stage 37.92 feet. Discharge 71 cubic feet per second. June 26, 1981. Minimum discharge in 1981, 48 cubic feet per second August 25 and 26.) 


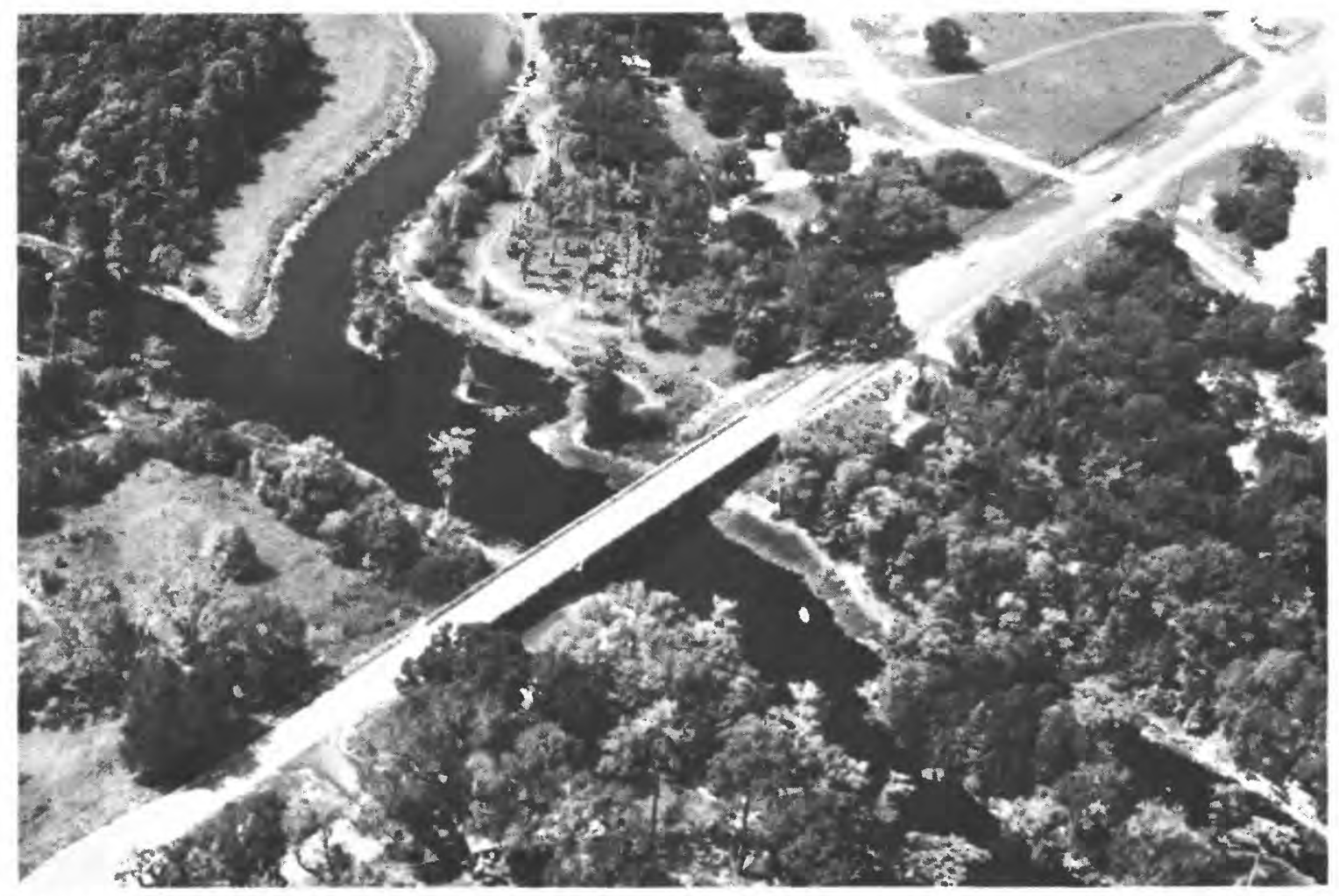

Figure 31. - Withlacoochee River near Holder (site 35). (Downstream to lower right. Upstream to left of photograph. Tsala Apopka Outfall Canal entering from top of photograph. Discharge, 157 cubic feet per second. Stage, 28.08 feet. June 26, 1981. Average discharge, 760 cubic feet per second. Median stage, about 2 feet higher.) 


\section{SUMMARY AND CONCLUSIONS}

This report presents (1) results of a reconnaissance of geohydrologic areas in the SWFWMD Withlacoochee River Basin, and (2) a description of the record low-flow conditions that occurred in the Withlacoochee River drainage basin during 1981.

The SWFWMD Basin is a water-management area of about $2,030 \mathrm{mi}^{2}$ in westcentral Florida which contains large reserves of potable ground water in the Upper Floridan aquifer. Results of reconnaissance test drilling during 1981-82 indicate that, though locally perched water-table conditions occur, the Upper Floridan aquifer may be considered an unconfined aquifer in the SWFWMD Basin. This allows the Basin to be divided into two types of geohydrologic areas: (1) areas of high recharge, and (2) areas of moderate recharge. The concept of geohydrologic areas is important to water management because large, sustained withdrawals of ground water from different geohydrologic areas may result in widely differing effects on the total hydrologic and surface environments.

Conceptually, the long-term effects of development of ground water from the two types of geohydrologic areas in the SWFWMD Withlacoochee River Basin would differ as follows. The source of water to well fields in areas of high recharge would largely be from natural occurring recharge; whereas in areas of moderate recharge, a significant part of the source of water to well fields would be induced downward leakage, or capture, of surface and near-surface water. Thus, sustained withdrawal of large quantities of ground water in areas of high recharge would result in minimal changes in amount of water available to the surface environment. Similar withdrawals in areas of moderate recharge would result in less water being available to the wetlands environment.

The SWFWMD Withlacoochee River Basin is drained almost entirely by the Withlacoochee River and its tributaries. Field data were collected from April 13 through August 17, 1981, to document extremely low-flow conditions. Conditions in the upper half of the basin were found to be the most severe of record; the river surface in some reaches was as much as 2.81 feet higher than the potentiometric surface of the Upper Floridan aquifer, and the river was losing water to the aquifer. Losses of $20 \mathrm{ft}^{3} / \mathrm{s}$, or more, were noted in some reaches. On July 7, 1981, the total net runoff from the upper half of the basin was observed to be only $0.1 \mathrm{ft}^{3} / \mathrm{s}$. Low-flow conditions in the lower half of the basin were less severe than during the record low period of 1956. The river was found to be gaining water from the Upper Floridan aquifer in most reaches of the lower half of the basin. The quality of water data collected in 1979 and in 1981 show that, in genera1, specific conductance hardness, base metals, alkalinity, bicarbonates, and dissolved solids are lower at high discharge than at low discharge; and that color and noncarbonate hardness are higher at high discharge than at low discharge. 
Anderson, Warren, and Laughlin, C.P., 1982, Geohydrology of the Floridan aquifer in the Withlacoochee River basin of the Southwest Florida Water Management District: U.S. Geological Survey Water-Resources Investigations Open-File Report $82-331,4$ sheets.

Bredehoeft, J.D., Papadopulos, S.S., Cooper, H.H., Jr., 1982, Groundwater: The water-budget myth, in scientific basis of water-resource management: Washington, National Academy Press, p. 51-57.

Buono, Anthony, and Rutledge, A.T., 1978, Configuration of the top of the Floridan aquifer, Southwest Florida Water Management District and adjacent areas: U.S. Geological Survey Water-Resources Investigations 78-34, 1 sheet.

Cooke, C.W., 1945, Geology of Florida: Florida Geological Survey Bulletin $29,339 \mathrm{p}$.

Deuerling, R.S., Jr., and MacGil1, P.L., 1981, Environmental geology series, Tarpon Springs sheet: Florida Bureau of Geology Map Series 99, 1 sheet.

Knapp, M.S., 1978, Environmental geology series, Gainesville sheet: Florida Bureau of Geology Map Series 79, 1 sheet.

Lohman, S.W., 1972, Definitions of selected ground-water terms--Revisions and conceptual refinements: U.S. Geological Survey Water-Supply Paper $1988,21 \mathrm{p}$.

Miller, J.A., 1986, Hydrogeologic framework of the Floridan aquifer system in Florida and in parts of Georgia, South Carolina, and Alabama: U.S. Geological Survey Professional Paper 1403-B, 91 p.

National Oceanic and Atmospheric Administration, Climatological data, Florida, annual summaries 1931-78.

Palmer W.C., 1965, Meteorological drought: U.S. Weather Bureau Research Paper No. $45,58 \mathrm{p}$.

Pride, R.W., Meyer, F.W., and Cherry, R.N., 1966, Hydrology of Green Swamp area in central Florida: Florida Geological Survey Report of Investigations $42,137 \mathrm{p}$.

Ryder, P.W., 1982, Digital model of predevelopment flow in the Tertiary limestone (Floridan) aquifer system in west-central Florida: U.S. Geological Survey Water-Resources Investigations 81-54, $61 \mathrm{p}$.

Scott, T.M., 1978, Environmental geology series, Orlando sheet: Florida Bureau of Geology Map Series 85, 1 sheet.

Theis, C.V., 1940, The source of water derived from wells: Essential factors controlling the response of an aquifer to development: Civil Engineering, v. 10, no. 5, p. 277-280.

Vernon, R.0., 1951, Geology of Citrus and Levy Counties, Florida: Florida Geological Survey Bulletin 33, 256 p.

White, W.A., 1970, The geomorphology of the Florida peninsula: Florida Bureau of Geology Bulletin 51, 164 p. 